\begin{abstract}
UNIVERSIDADE DE SÃO PAULO
INSTITUTO DE RELAÇÕES INTERNACIONAIS

PROGRAMA DE PÓS-GRADUAÇÃO EM RELAÇÕES

INTERNACIONAIS
\end{abstract}

JULIANA JERÔNIMO COSTA

O FORTALECIMENTO DAS RELAÇÕES BILATERAIS E

O APOIO NOS FOROS MULTILATERAIS: AS

RELAÇÕES BRASIL-ÁFRICA (1995-2010)

São Paulo

2014 


\author{
UNIVERSIDADE DE SÃO PAULO \\ INSTITUTO DE RELAÇÕES INTERNACIONAIS \\ PROGRAMA DE PÓS-GRADUAÇÃO EM RELAÇÕES \\ INTERNACIONAIS
}

\title{
O FORTALECIMENTO DAS RELAÇÕES BILATERAIS E O APOIO NOS FOROS MULTILATERAIS: AS RELAÇÕES BRASIL-ÁFRICA (1995-2010)
}

JULIANA JERÔNIMO COSTA

Tese apresentada ao Programa de PósGraduação em Relações Internacionais do Instituto de Relações Internacionais da Universidade de Relações Internacionais, para a obtenção do título de Doutor em Relações Internacionais

Orientador (a): Professora Titular Maria Hermínia Tavares de Almeida.

São Paulo 
Á Deus e aos meus pais. 



\section{Agradecimentos}

Ao longo dessa caminhada que é finalizada por meio da apresentação dessa tese, tive o apoio e a solidariedade de muitas pessoas. Agora é chegado o momento de agradecer a todos que fizeram parte de minha jornada até aqui.

Gostaria de agradecer, primeiramente, à minha orientadora Maria Hermínia Tavares de Almeida, uma intelectual da mais alta capacidade e generosidade, pois nos momentos mais difíceis, me deu todo o apoio e tranquilidade necessários para que pudesse recuperar a minha saúde e dar continuidade à minha pesquisa.

Também agradeço a compreensão de todos os membros do Instituto de Relações Internacionais que permitiram o meu afastamento do programa quando foi necessário. No Instituto tive a oportunidade também de conviver com professores, cujos ensinamentos serão valiosos para sempre. Obrigada aos professores, Janina Onuki, que desde a participação em minha defesa de mestrado me apoiou para entrar no doutorado no IRI, à Adriana Schor, cujas sugestões na banca de qualificação contribuíram muito para a conclusão dessa pesquisa, Amâncio Jorge de Oliveira, Maria del Tedesco Lins e Leandro Piquet. Também agradeço ao auxílio recebido pela secretaria da pós-graduação IRI pela Giselle Castro.

Aos membros dessa banca obrigado por terem aceito o convite para fazer parte da defesa dessa tese.

Aproveito a oportunidade para agradecer a todos da minha turma do IRI-USP pela proveitosa convivência ao longo desses anos na USP, aprendi muito com todos vocês.

Aos meus amigos e professores do Programa de Pós-Graduação em Relações Internacionais San Tiago Dantas, em especial à Helena Margarido Moreira, Priscila Morrone, Bernardo Wahl Gonçalves e Viviane Sá, muito obrigado pelo apoio e pelas discussões ao longo desses anos.

À Fecap, instituição em que trabalho, e a todos os seus professores, que sempre valorizaram a continuidade de minhas pesquisas acadêmicas, em especial aos colegas Claudia Alvarenga Marconi, Glauco Peres da Silva e Emanuel de Oliveira, pela amizade e aos dois últimos também por me ajudar com as questões quantitativas dessa pesquisa.

Também agradeço a Ivan Almeida Lopes Fernandes por sua inestimável ajuda e paciência com o modelo quantitativo proposto nessa tese. 
Não poderia deixar de agradecer, especialmente, conforme prometido, ao meu médico Filipe Saad que foi um dos maiores responsáveis por ter conseguido chegar até esse momento em plena saúde.

Aos meus familiares e amigos, pela compreensão, confiança e afeto que me permitiram finalizar mais uma etapa da minha jornada acadêmica. Sem vocês, nada disso teria sido possível: Muito Obrigada!!! 


\section{Resumo}

COSTA, Juliana $\mathrm{J}$. O fortalecimento das relações bilaterais e o apoio nos foros multilaterais: as relações Brasil-África (1995-2010). 2014. Tese (Doutorado) Instituto de Relações Internacionais, Universidade de São Paulo, São Paulo, 2014.

Essa tese tem como problema de pesquisa verificar se as estratégias de fortalecimento do relacionamento bilateral aumentariam o apoio dos países beneficiados ao país beneficiário nos foros multilaterais. Acredita-se, portanto, que uma das motivações para que os países fortaleçam as suas relações bilaterais seria a conquista de apoio no plano multilateral para com isso aumentar o seu peso e prestígio no sistema internacional.

A literatura disponível responde a essa pergunta por meio de pesquisas sobre a ligação entre a ajuda internacional fornecida pelos países desenvolvidos, principalmente os Estados Unidos, e a convergência de votos em organismos multilaterais, não investigando se pode existir relação semelhante no caso de países emergentes.

Dessa maneira, essa tese, por meio do estudo das relações Brasil-África entre os anos 1995 e 2010 - período em que o Brasil perseguiu um maior protagonismo no sistema internacional - busca tratar essa lacuna, objetivando verificar se o incremento das relações bilaterais gera a convergência de votos entre os envolvidos na Assembleia Geral das Nações Unidas.

Para atingir esse objetivo, essa pesquisa foi dividida em quatro capítulos. No primeiro, são apresentados os principais estudos relativos à "troca" de benesses bilaterais por apoio nos foros multilaterais.

No segundo capítulo, será feita uma análise das linhas gerais política externa africana nos governos FHC e Lula, por meio da análise da bibliografia nacional, de discursos e dados oficiais como o número de viagens presidenciais à região e a abertura de embaixadas variáveis. Na segunda parte, são apresentados os dados relativos às variáveis escolhidas como indicativos da estratégia de conquista de aliados no continente africano para as demandas brasileiras no plano multilateral - o fluxo comercial bilateral e o número de projetos de cooperação técnica entre o Brasil e continente africano. 
O último capítulo, quantitativo, está dividido em quatro partes. $\mathrm{Na}$ primeira, justifica-se a escolha da Assembleia Geral das Nações (AGNU) como parâmetro para o alinhamento no plano internacional. Na segunda é apresentada a metodologia a ser utilizada para revelar as possíveis relações entre as variáveis escolhidas, bem como o modelo a ser utilizado para a verificação da hipótese central de pesquisa. Na terceira, serão apresentados os dados recolhidos e a estatística descritiva dos mesmos bem como os possíveis resultados a serem encontrados por meio da análise quantitativa. Na última parte, serão apresentados os resultados encontrados na análise quantitativa dos dados e se a hipótese de pesquisa teria sido comprovada ou não.

Palavras-chaves: Política Externa Brasileira - Relações Brasil-África - ONU 


\begin{abstract}
COSTA, Juliana J. Strengthening bilateral relations and support in multilateral forums: Brazil-Africa relations (1995-2010). 2014. Tese (Doutorado) - Instituto de Relações Internacionais, Universidade de São Paulo, São Paulo, 2014.
\end{abstract}

This research aim to examine whether the strengthening of bilateral relations increases the support of recipient countries to the beneficiary country in multilateral forums. We believe, therefore, that one of the motivations for countries to strengthen their bilateral relations would be the support at the multilateral level in order to increase their weight and prestige international system.

The literature answers this question through research on the link between foreign aid provided by developed countries, especially United States, and voting convergence in multilateral organizations, not exploring whether exists a similar relationship in case of emerging countries.

Thus, this thesis, by studying the Brazil-Africa relations between 1995 and 2010 - a period in which Brazil has pursued a major role in the international system - seeks to address this gap, to check whether the increase in bilateral relations generates voting convergence in the UN General Assembly.

To achieve this goal, this research is divided into four chapters. In the first, the main studies on the "exchange" of bilateral handouts for support in multilateral forumsare presented. In the second, we analysis the brazilian African foreign policy in FHC and Lula governments, through the analysis of national literature, speeches and official data as the number of presidential trips to the region and the opening of embassies. In the second part, the data on the variables chosen as indicative of the strategy to gain support to the Brazilian demands on multilateral foruns - the bilateral trade flow and the number of technical cooperation projects between Brazil and Africa are

presented.

The last chapter, quantitative, is divided into four parts. At first, we justify the choice of United Nations General Assembly (UNGA) as a parameter for international alignment. The second presents the methodology used to reveal the possible relationships between 
the selected variables and the model used for checking the hypothesis. In the third, the collected data and descriptive statistics of the variavles and the possible results to be found by quantitative analysis will be presented. In the last part, the results in quantitative data analysis and research hypothesis are presented to prove or not our hypothesis.

Keywords: Brazilian Foreign Policy - Brazil-Africa relations - UN 


\section{Sumário}

Lista de Abreviaturas

Lista de Figuras

Lista de Tabelas

Introdução .1

CAPÍTULO I - OS MECANISMOS BILATERAIS E A CONQUISTA DO APOIO $\begin{array}{llll}\text { DOS NOSTAOS NOROS } & \text { NOS }\end{array}$

MULTILATERAIS. .7

CAPÍTULO II - AS RELAÇÕES BRASIL-ÁFRICA NOS ANOS RECENTES (1995-2010) .20

2.1. As regiões de interesse das políticas exteriores de FHC e Lula em números .20

2.2. As linhas da política africana em perspectiva comparada............................................27

2.3. O fluxo comercial entre o Brasil e o continente africano entre 1995 e $2010 \ldots \ldots \ldots \ldots . . . . . . .35$

2.4. A cooperação técnica entre $\mathrm{o}$ Brasil $\mathrm{e}$ a África 45

2.5. Considerações finais do capítulo..........................................................................

CAPÍTULO III - A CONVERGÊNCIA ENTRE O BRASIL E ÁFRICA NA ASSEMBLEIA GERAL DAS NAÇÕES UNIDAS (AGNU). 
3.1. A utilização das votações na AGNU como parâmetro para medição das orientações $\begin{array}{llll}\text { gerais das } & \text { políticas }\end{array}$ Estados

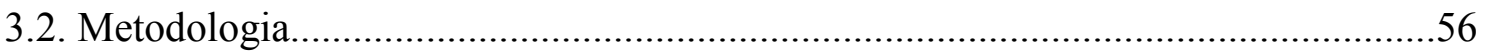

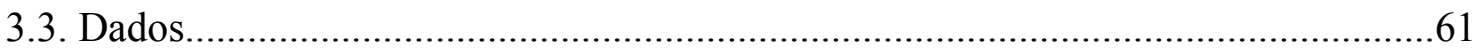

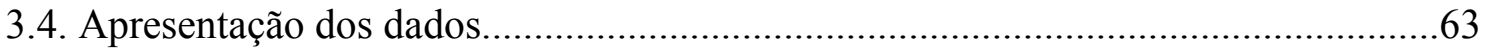

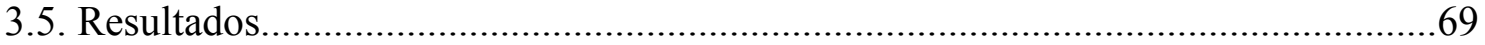

Conclusão.

Referências

Bibliográficas. 78

\section{Lista de Abreviaturas}

ABC Agência Brasileira de Cooperação

AFRICA The African Foreign Relations and International Conflict Analysis

AGNU Assembleia Geral das Nações Unidas

APEX Agência Brasileira para Promoção das Exportações

BNDES Banco Nacional de Desenvolvimento Econômico e Social

CEDEAO Comunidade Econômica dos Estados da África Ocidental

COOP Cooperação

CPLP Comunidade de Países de Língua Portuguesa

CSNU Conselho de Segurança das Nações Unidas

CTPD Cooperação Técnica para o Desenvolvimento

DAF Divisão da África

DAI Divisão de Atos Internacionais

DEAF Departamento da África

EA Efeitos Aleatórios

ECOWAS Comunidade Econômica dos Estados da África Ocidental

EF Efeitos Fixos

EUA Estados Unidos da América

EXP Exportação 
FAO Organização das Nações Unidas para Alimentação e Agricultura

FHC Fernando Henrique Cardoso

FMI Fundo Monetário Internacional

FUNAG Fundação Alexandre de Gusmão

G7 Grupo dos Sete

IGAD Autoridade Intergovernamental para o Desenvolvimento

IMP Importação

IPEA Instituto de Pesquisa Econômica Aplicada

MDIC Ministério do Desenvolvimento, Indústria e Comércio

MPLA Movimento pela Libertação de Angola

MRE Ministério das Relações Exteriores

NEPAD Nova Parceria para o Desenvolvimento da África

OCDE Organização para Cooperação e Desenvolvimento

OMC Organização Mundial do Comércio

ONU Organização das Nações Unidas

PED Países em Desenvolvimento

PEI Política Externa Independente

PIB Produto Interno Bruto

PMDR Países de Menor Desenvolvimento Relativo

POLS Pooled Regression Model

PT Partido dos Trabalhadores

SADC Comunidade para o Desenvolvimento da África Austral

UA União Africana

UMA União Árabe do Magreb

UNCTAD Conferência das Nações Unidas para o Comércio e Desenvolvimento

URSS União das Repúblicas Socialistas Soviéticas

ZOPACAS Zona de Paz e Cooperação do Atlântico Sul 


\section{Lista de Figuras}

1. Visitas bilaterais por região. . .21

2. Evolução

do

destino

das

exportações brasileiras. .22

3. Participação das regiões nas exportações brasileiras 23

4. Destino das exportações brasileiras por governo. .23

5. Participação

dos mercados

nas exportações brasileiras. .24

6. Evolução das importações brasileiras. .25

7. Participação nas importações brasileiras por região .25

8. Origens das importações

brasileiras

por mercado. .26

9. Participação dos mercados nas importações totais brasileiras 
10. Embaixadas

África. 33

11. Participação da África nas exportações brasileiras por governo .35

12. Exportações

para

$\mathrm{a}$

África

por governo .36

13. Participação das regiões africanas nas exportações para a África. 37

14. Mercados compradores na África. .38

15. Produtos exportados

para

África 38

16. Participação

africana nas importações

brasileiras

por governo .39

17. Volume das importações

originárias da África por governo .40

18. Participação das regiões africanas nas importações originárias da África. .41

19. Mercados

fornecedores

por governo . .41

20. Fluxo comercial com a África por governo . .42

21. Quadro comparativo de beneficiados e áreas da CTPD por governo...... .48

22. Participação das regiões nos projetos de CTPD para a África . .48

23. Participação por país na CTPD para a África. .49

24. Participação por país na CTPD para a África. . .49

25. Projetos de cooperação na África por área . .50

26. A presença brasileira na

África. .52 
27. Modelo

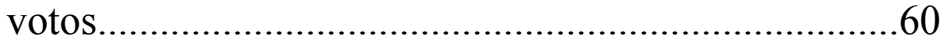

28. Evolução da participação brasileira nas importações africanas..................................64

29. Evolução da participação brasileira nas importações africanas por governo..............65

30. Evolução da participação brasileira nas exportações africanas.................................65

31. Evolução da participação brasileira nas exportações africanas por governo...............66

32. Evolução dos projetos de cooperação bilateral BrasilÁfrica....................................67

33. Evolução da convergência Brasil-África na AGNU por ano......................................67

34. Evolução da convergência Brasil-África na AGNU por governo..............................68

35. Margens de predição com $\quad$ a variável Lula............................................................ 72 


\section{Lista de Tabelas}

1. Embaixadas por

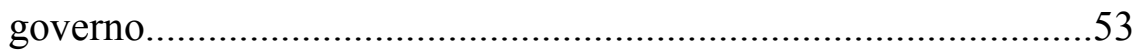

2. Descrição das

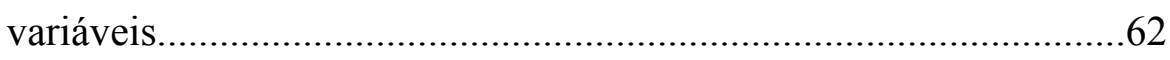

3. Estatísticas Descritivas das

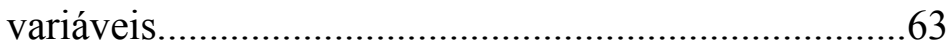

4. Coeficiente de Correlação com a ariável importação.................................................70

5. Coeficiente de Correlação com a exportação.......................................................... 72 


\section{Introdução}

O tema dos determinantes que levariam a um país apoiar o outro nos organismos multilaterais - locus para a discussão dos principais temas internacionais e onde os países buscam convencer seus pares sobre a importância de suas demandas - desperta o interesse dos pesquisadores das Relações Internacionais há um tempo. Como ocorre esse processo de convencimento, ou seja, por meio de quais mecanismos um país pode conquistar os votos e o apoio de outros países nos foros multilaterais?

Apesar de avançada, essas pesquisas possuem uma lacuna: não tratam dos países emergentes que tem, cada vez mais, um peso maior no sistema internacional, deixando em aberto algumas perguntas sobre como um país emergente, cujo poder econômico e político é mais limitado, poderia angariar aliados à sua agenda nas organizações multilaterais? Uma das possibilidades seria agraciar os seus possíveis aliados com benefícios no plano multilateral, mas quais seriam esses possíveis benefícios, no caso de um país emergente? Esse fortalecimento das relações bilaterais realmente gera o apoio no plano multilateral? 
Essa tese, portanto, tem como problema de pesquisa verificar se as estratégias de fortalecimento do relacionamento bilateral aumentariam o apoio dos países beneficiados ao país beneficiário nos foros multilaterais. Acredita-se, portanto, que uma das motivações para que os países fortaleçam as suas relações bilaterais seria a conquista de apoio no plano multilateral para com isso aumentar o seu peso e prestígio no sistema internacional.

Um dos principais elementos da política exterior de um país é a sua atuação nos foros multilaterais, pois por meio da mesma, os Estados interagem com os seus pares no sistema internacional e buscam aliados que possam favorecer as suas demandas em relação à comunidade internacional. Entretanto, ainda não estão totalmente claros o que determinaria esse apoio por parte dos países no plano internacional. Nesse sentido, essa tese tem como tema a investigação de possíveis determinantes desse apoio, destacando o fortalecimento do relacionamento bilateral como uma estratégia para alcançar a cooperação de outros Estados no plano multilateral.

A questão da cooperação entre os países no plano internacional é um tema que há muito tempo preocupa os analistas de relações internacionais que procuram apontar quais seriam os elementos que levariam os Estados a cooperarem no plano internacional, principalmente nas instituições multilaterais que, cada vez mais, possuem um peso maior na disseminação não apenas de informação, mas também como arena de poder para os países no sistema internacional.

Dessa maneira, países com menor poder relativo ou recursos limitados utilizarse-iam dos foros multilaterais como um mecanismo para alcançar o atendimento de suas demandas no sistema internacional vigente. Ademais, certos "status", como o de membro permanente do mais alto órgão da principal instituição multilateral - o Conselho de Segurança das Nações Unidas (CSNU) - conferiria ao Estado que o alcançasse maior poder relativo e capacidade de atuação no sistema internacional.

Para isso, o Estado lançaria mão das mais diversas estratégias para conquistar aliados ao seu projeto de projeção no sistema internacional, utilizando-se de mecanismos como viagens presidenciais e ministeriais, abertura de postos diplomáticos nos países e regiões de interesse, incremento do comércio bilateral e acordos de cooperação técnica, dentre outros.

Essa hipótese acerca da utilização de estratégias bilaterais para conquistar apoio nos foros multilaterais é relativamente antiga, datando dos anos 60. Entretanto, boa parte dessa literatura trata apenas dos países desenvolvidos, principalmente da ligação 
entre ajuda externa fornecida pelos Estados Unidos e o apoio dos receptores a esse país na Organização das Nações Unidas (ONU). Existindo, portanto, poucos estudos que procuram verificar essa ligação entre fortalecimento do relacionamento bilateral e apoio nos foros multilateral em relação aos países em desenvolvimento que, nos anos recentes, tem aumentado, cada vez mais, a sua presença e o seu poder nos foros multilaterais.

Visando suprir essa lacuna, utilizaremos o relacionamento bilateral entre Brasil e África, para investigar como ocorre esse processo de conquista de apoio por parte de países emergentes. A escolha desse relacionamento não foi aleatória, pois nos anos recentes a diplomacia teria empreendido esforços para melhorar a sua relação com os países em desenvolvimento, por meio das relações Sul-Sul, com vistas a angariar aliados dentro da comunidade internacional para apoiar as suas demandas nos foros multilaterais e, consequentemente o seu peso no sistema internacional de poder.

A opção por estudar as relações com o continente africano deve-se ao fato de que este teria recebido destaque na política externa brasileira a partir da ascensão do presidente Luís Inácio Lula da Silva, cuja estratégia de política exterior estaria baseada, dentre outras, no incremento do relacionamento com os países do Sul. Ademais, o continente africano vem experimentando taxas de crescimento bastante significativas, a partir dos anos 2000, com países como Angola com PIBs chegando a 20\% e Cabo Verde com índices de inflação na casa dos 4\% (Fonte: FMI).

O continente, a partir de fatores como a como a redução drástica de seus conflitos violentos e o consequente aumento na ajuda internacional, também passou a atrair mais investimento externo direto, sendo que no período a ser analisado nessa tese, cresceu 200\%, passando de US\$ 18,9 milhões em 2003 para US\$ 43,1 milhões (Fonte: UNCTAD). É claro que a África partiu de um ponto bastante inferior, mas ainda assim esses números são relevantes e demonstram uma tendência que não pode passar despercebida por países, como o Brasil, que desejam aumentar suas zonas de influência.

Hoje, portanto, a África desperta o interesse de diversos países, principalmente de outros países intermediários como o Brasil, como a China e a Índia, que estariam interessados no continente como um fornecedor de recursos naturais para seu processo de industrialização e modernização. Dessa maneira, a região passa a ser considerada um elemento importante na política externa dos países, não apenas pelo seu novo peso econômico, mas também pelo apoio político que pode conferir aos objetivos dos Estados com os quais firma alianças. 
Essa análise será feita não apenas por meio do estudo do governo Lula, que, segundo alguns autores teria iniciado esse tipo de estratégia, mas sim pelo estudo comparado com o governos Fernando Henrique Cardoso, para que por meio da indicação das possíveis diferenças entre as estratégias de política exterior dos dois governos em questão seja possível proporcionar uma avaliação mais próxima da realidade, já que o exame isolado de apenas um governo não traria a resposta à pergunta de pesquisa, pois não seria possível verificar o peso da mudança de estratégia no perfil de atuação dos países africanos em relação ao Brasil.

Ademais, o período escolhido seria interessante por outros motivos, como o fato de corresponder a um período razoavelmente longo, 16 anos. Além disso, no intervalo em questão, o Brasil foi governado por dois presidentes cujos partidos apresentam perfis ideológicos/programáticos bem distintos e que ficaram no poder pelo mesmo período de tempo, o que nos permitiria demonstrar possíveis influências da política doméstica sobre a política externa (GOUREVITCH, 2002).

Ademais, metodologicamente a utilização de um governo de maneira isolada não traria a possibilidade de controle dos dados quantitativos, sendo, portanto, necessária uma série temporal.

A partir das considerações supracitadas, parte-se das seguintes hipóteses secundárias que serão trabalhadas em capítulos específicos, sendo elas:

- O Brasil, para angariar o apoio dos outros Estados no plano multilateral, teria lançado mão de estratégias bilaterais, como comércio e cooperação técnica, com relação aos países africanos, para com isso, garantir um papel mais destacado no cenário internacional e para que esses países apoiem suas demandas por uma ordem internacional mais favorável aos seus interesses;

- Graças às estratégias supracitadas, os países africanos passaram a apoiar mais o Brasil nos foros multilaterais durante o período analisado.

Para a consecução das metas supracitadas, tipos diferentes de abordagem quantitativa e qualitativa.

Portanto, além do uso da abordagem quantitativa será promovido o diálogo com a bibliografia de cunho histórico (produções de analistas de política externas e documentos e dados oficiais), visando reconstituir relacionamento do Brasil com o continente africano nos dois governos supracitados. Também será a bibliografia disponível acerca do tema da utilização de estratégias bilaterais com vistas a consecução 
de apoio nos foros multilaterais, para, por meio dessa, ser possível identificar as possíveis estratégias empreendidas pelo Brasil em relação à África.

Utilizaremos também documentos oficiais como pronunciamentos e escritos de membros de cada governo, como os presidentes e seus ministros de relações exteriores. A escolha da documentação primária decorre do fato de que os mesmos podem indicar as modificações na base de poder em que se assentam as relações entre os países, na orientação ideológica de cada governo, ou ainda na correlação de forças domésticas que serviriam de apoio a um determinado projeto político.

Entretanto, a pesquisa não pode ficar restrita a esse único tipo de fonte de informações, já que mesmo que a análise do discurso diplomático, mesmo que permita a identificação de determinados conceitos em pronunciamentos oficiais, não seria suficiente para avaliar a natureza da política externa em foco, pois os mesmos acabam, por sua natureza oficial, deixar de lado algumas questões importantes. Dessa maneira, pretende-se ultrapassar essa possível falha complementando a análise qualitativa com artigos e livros de importantes pesquisadores da política externa brasileira para o continente africano.

A comprovação empírica da hipótese principal dessa tese será feita por meio análise dos votos conjuntos entre o Brasil e o continente africano na Assembleia Geral das Nações Unidas (AGNU) entre os anos de 1995 e 2010. A escolha dessa medida quantitativa justifica-se, pois a assembleia seria o único fórum em que um grande número de Estados se encontram e votam em bases regulares sobre assuntos concernentes à comunidade internacional. Dessa forma, o estudo dessa interação em um longo período e sobre diferentes áreas revelaria possíveis modificações no comportamento dos Estados e na dimensão do conflito global (VOETEN, 2000, p. 185$6)$.

Para isso, será utilizada a base de dados construída por Erik Voeten e Adir Merdzanvic (2012) que verificaram a convergência entre pares de países em 4.900 resoluções da AGNU entre os anos de 1946 e 2012.

A tese está dividida em quatro capítulos. No primeiro, serão apresentados os principais estudos em relações internacionais relativos à questão da "troca" de benesses bilaterais por apoio nos foros multilaterais, mais notadamente a Assembleia Geral das Nações Unidas que, conforme explicitado anteriormente, será o foro escolhido para a análise empírica. Nesse capítulo, será explorada a literatura que procura estabelecer uma ligação entre a ajuda externa e o comportamento de votação dos Estados na ONU. 
No segundo capítulo, dividido em duas partes, será feita uma análise, primeiramente, a partir de autores brasileiros e discursos oficiais, das linhas gerais política externa africana nos governos FHC e Lula, por meio da análise da bibliografia nacional, de discursos e dados oficiais como o número de viagens presidenciais à região e a abertura de embaixadas variáveis que posteriormente serão utilizadas para o estudo quantitativo.

$\mathrm{Na}$ segunda parte, serão apresentados os dados relativos às duas variáveis escolhidas como indicativos da estratégia de conquista de aliados no continente africano para as demandas brasileiras no plano multilateral - o fluxo comercial bilateral e o número de projetos de cooperação técnica entre o Brasil e continente africano. A escolha dessas duas variáveis seria justificada, pois por meio dessas estratégias, o governo brasileiro conseguiria aproximar-se de seus possíveis aliados e, consequentemente, "comprar" seus votos, conforme a bibliografia sobre o tema propõe.

O último capítulo está dividido em quatro partes. Na primeira parte, será justificada a escolha da Assembleia Geral das Nações (AGNU) como parâmetro para o alinhamento no plano internacional (TOMLIN, 1985; VOETEN, 2000). Na segunda será apresentada a metodologia a ser utilizada para revelar as possíveis relações entre as variáveis escolhidas, bem como o modelo a ser utilizado para a verificação da hipótese central de pesquisa. Na terceira, serão apresentados os dados recolhidos e a estatística descritiva dos mesmos bem como os possíveis resultados a serem encontrados por meio da análise quantitativa. Na última parte, serão apresentados os resultados encontrados na análise quantitativa dos dados.

Por fim, na conclusão, ao juntar-se aquilo que foi apontado na primeira parte por meio da bibliografia analítica e dos documentos oficiais e os resultados da análise quantitativa será possível responder ao problema de pesquisa dessa tese, que seria, conforme supracitado, se o fortalecimento do relacionamento bilateral refletir-se-ia em aumento do apoio da região beneficiada nos foros multilaterais.

Portanto, essa tese, a partir da análise sobre o Brasil, poderá contribuir para o estudo das questões acerca da ação dos países emergentes no sistema internacional, a partir do exame das estratégias empreendidas pelo Brasil para angariar o apoio de outros países do sistema internacional a suas demandas e, com isso, alavancar a sua projeção no plano global, complementando as pesquisas que já existem sobre a questão das estratégias utilizadas pelos países no plano internacional para angariar o apoio dos Estados nos foros multilaterais. 


\section{CAPÍTULO I - OS MECANISMOS BILATERAIS E A CONQUISTA DO APOIO DOS ESTADOS NOS FOROS MULTILATERAIS}

Um importante tópico de pesquisa na área de Relações Internacionais é o estudo da cooperação internacional, em particular, a pesquisa tem buscado examinar os fatores que tem influenciado o grau de cooperação entre dois Estados, muitas vezes olhando para indicadores observáveis de cooperação como formação de aliança, assistência externa ou comprometimento com instituições internacionais.

A teoria da dependência sustenta que Estados fracos responderiam de maneira positiva a muitos desses incentivos, aceitando recompensas como comércio, ajuda externa ou investimentos de Estados mais poderosos ao concordarem com as preferências políticas das potências (MOON, 1985).

Dessa maneira, assim como no plano interno, seria comum a utilização de incentivos econômicos para conquistar a influência política no âmbito internacional. Entretanto, no âmbito internacional, o que seria "comprado" não seria a possibilidade 
permanência no poder, como ocorre no plano doméstico, mas sim, conforme apontado por Dreher e Vreeland (2014, p. 4), a legitimidade para suas políticas externas.

Segundo Morgenthau (1952, p. 302), a transferência de dinheiro e serviços de um governo para outro seria um preço pago por serviços políticos prestados ou a serem prestados.

Para Keohane (1966, p. 19), alguns Estados, em foros multilaterais, como a Assembleia Geral das Nações Unidas (AGNU) estariam mais suscetíveis a pressões bilaterais, não importando o quão a sua aplicação possa ser sutil, quanto mais dependente um Estado for em termos de comércio, ajuda ou proteção, mais suscetível será à pressão por parte do Estado mais poderoso. Ademais, ameaças de retaliação de qualquer tipo como a suspensão da ajuda externa, normalmente, não precisam ser explicitadas, sendo suficiente para o Estado menos poderoso estar ciente de que a potência está acompanhando todos os seus passos (KEOHANE, 1966, p. 19).

Nesse sentido, uma extensa literatura quantitativa começou, nos anos 60, a examinar os padrões de votação na AGNU (ALKER, 1964; RUSSETT, 1966; NEWCOMBE, ROSS, NEWCOMBE, 1970; HAGAN, 1989; KIM, RUSSETT, 1996; VOETEN, 2000), contribuindo para o entendimento dos padrões de votações na AGNU bem como sobre as alianças que se formam no principal foro multilateral, enfatizando, principalmente a identificação de preferências semelhantes como uma das maneiras para analisar a constituição de alianças entre países nas organizações internacionais multilaterais.

Em seu exame sobre essa literatura que nascia à época, Keohane (1967) apontou que a mesma poderia trazer importantes contribuições para a área de relações internacionais por meio da pesquisa de três importantes questões: 1) como as deliberações ocorreriam na AGNU; 2) quais os padrões de votação que emergem dessas deliberações; e 3) quais os processos políticos que informariam as deliberações e produziriam os padrões de votação observados.

A partir desses estudos mais amplos sobre os padrões de votação na AGNU, surgiu uma literatura, também na década de 60 , que buscou investigar o possível uso da ajuda externa por parte dos EUA para influenciar os votos dos países na ONU (WILCOX, 1962; MASON, 1964; WOLF JR., 1964; WESTWOOD, 1966; KAPLAN, 1967; PLANO; RIGGS, 1967; BLACK, 1968).

Esses primeiros estudos possuem um componente normativo importante, apontando que os votos da ONU não deveriam ser o determinante primário das decisões 
acerca da alocação de ajuda, o que sugeriria que a ajuda externa e os votos na AGNU não seriam randomicamente associados (BLACK, 1968; MASON, 1964; WOLF JR., 1964; KAPLAN, 1967).

Um dos principais estudos das primeiras pesquisas acerca da relação entre ajuda e votações na AGNU é desenvolvido por Andrew Westwood (1966) que buscaria verificar a hipótese de que o alinhamento dos países menos desenvolvidos na Guerra Fria teria sido uma preocupação dos EUA por duas razões: primeiro, por causa da necessidade de apoio ideológico geral na competição contra a URSS; segundo, devido à necessidade de cooperação em uma série de assuntos e problemas, notadamente na ONU.

Westwood (1966, p. 105) conclui que os esforços de alguns países para fazer com que a ajuda se transformasse em serviços por parte dos beneficiados pela mesma para propósitos de apoio ideológico - provavelmente não seriam muito necessários, já que a utilização da ajuda externa para promoção da cooperação em uma série de assuntos e problemas específicos tornou-se, ao longo de tempo, mais importante que a questão ideológica. Isso ocorreria porque conforme os países menos desenvolvidos teriam entrado na ONU, a necessária maioria para a aprovação das resoluções tem crescentemente dependido de seus votos, pois estes estariam maior número, sendo, portanto, imperativa o atendimento das demandas desses países que não estariam tão preocupados com a clivagem ideológica à época.

Nos anos 80, essa literatura sofisticou-se ainda mais, procurando identificar como e quando as principais potências "comprariam" votos por meio da ajuda externa para obter os resultados esperados em suas estratégias de política externa (WITTKOPF, 1973; RAI, 1980; KEGLEY e HOOK, 1991; WANG, 1999).

Essa preocupação com a efetividade da ajuda externa em influenciar os votos dos países receptores na ONU aumentou nos anos 80 devido à forte erosão do apoio dos Estados na ONU durante o governo do presidente Ronald Reagan. Para conter esse processo, a sua administração ordenou uma avaliação do papel dos EUA nas instituições multilaterais e começou a monitorar o comportamento de política externa dos receptores da ajuda norte-americana. Pouco tempo depois, o congresso norte-americano autorizou o presidente a reter a ajuda a países que votassem regularmente contra as posições norte-americanas na ONU, estabelecendo, portanto, a partir daquele momento, uma ligação entre as alocações de ajuda e as votações na ONU (KEGLEY; HOOK, 1991). 
Além das tradicionais motivações relativas à assistência ao desenvolvimento dos países menos desenvolvidos, os governos doadores, portanto, também levariam em conta, em suas alocações de ajuda externa, seus próprios interesses nacionais, mesmo que isso pudesse ser concebido em termos de manutenção de esferas de influência, alianças políticas ou militares, ou simplesmente para promover as suas exportações (MAIZELS; NISSANKE, 1984, p. 879).

$\mathrm{Na}$ tentativa de buscar uma ligação externa entre doadores e receptores, Maizels e Nissanke (1984, p. 884) apontam três categorias que poderiam motivar a alocação de ajuda externa por parte dos doadores: interesses políticos e de segurança; interesses de investimentos; e interesses comerciais ${ }^{1}$. Os autores chegaram à conclusão de que os interesses políticos ou de segurança dominaram os resultados ${ }^{2}$.

Como os principais doadores encontram-se no mundo desenvolvido, o estudo da relação entre ajuda externa e comportamento de votação na AGNU está concentrado nos países mais ricos.

Um dos primeiros autores a estudar essa temática, ainda nos 70 , foi William Wittkopf (1973), que buscou verificar, a partir de um modelo de política externa comparada, a existência de uma relação entre resultados políticos na AGNU e as alocações de ajuda externa, acreditando na hipótese de que quanto maior a concordância entre um Estado em desenvolvimento e um país doador, maior seria o montante de ajuda proveniente desse doador.

Para isso, Wittkopf (1973, p. 868) focou inicialmente nos EUA para, posteriormente, comparar os resultados relativos aos EUA com outros doadores do bloco soviético e da Organização para Cooperação e Desenvolvimento (OCDE), encontrando uma associação, consistente ao longo do tempo, entre alocação de ajuda e padrão de votação apenas no caso dos EUA, sendo que no caso do bloco soviético essa associação teria ocorrido, mas não teria sido consistente ao longo do período analisado

\footnotetext{
${ }^{1}$ Os interesses políticos e de segurança foram medidos a partir da existência de um tratado de defesa ou alguma outra forma de associação política ou militar, como transferências de armas pelos doadores. O componente político foi tratado a partir do objetivo de manutenção ou expansão de uma esfera de interesse a antigas colônias ou regiões em particular. Os interesses de investimento seriam a promoção do crescimento econômico ou o alívio de dificuldades econômicas em um país em desenvolvimento no qual o doador tem investimentos substanciais. O interesse comercial seria a promoção do crescimento ou alívio de dificuldades econômicas em países em desenvolvimento que seriam seus principais parceiros comerciais (MAIZELS; NISSANKE, 1984, p. 884).

${ }^{2}$ Cabe destacar que o estudo foi realizado no período da Guerra Fria, no qual os interesses das grandes potências eram fortemente influenciados por questões relativas à segurança internacional e à manutenção de esferas de influência.
} 
pelo autor ${ }^{3}$. Portanto, aparentemente, o comportamento de votação dos países em desenvolvimento seria irrelevante para as preocupações da maioria dos doadores de ajuda.

Apesar da relação positiva encontrada, Wittkopf (1973, p. 887) alerta que mesmo na relação entre alocação de ajuda e os votos observados para os EUA, não estaria claro qual das duas variáveis deveria ser considerada causa e qual deveria ser considerada consequência.

Portanto, as pesquisas conduzidas nos anos 70 e 80 revelaram que doadores bilaterais em grande parte perseguiram seus próprios interesses quando alocaram ajuda aos seus receptores. Entretanto, apesar da popularidade da noção de que os votos da AGNU seriam muito influenciados pelos esforços dos países doadores em comprar votos, não existiriam evidências empíricas muito convincentes para apoiar esse argumento ${ }^{4}$.

Sendo assim, a retórica dos doadores - de que seus objetivos seriam altruístas e que gostariam de ajudar no desenvolvimento econômico e social dos receptores - estaria em conflito com os estudos empíricos mais recentes (SCHRAEDER ET AL., 1998; ALESINA; DOLLAR, 2000; ALESINA; WEDER, 2002; KUZIEMKO; WERKER, 2006).

Nos anos recentes, a pesquisa sobre a cooperação com os EUA na ONU pode ser resumida em duas vertentes: a primeira teria como foco o fato de que as clivagens na ONU refletiriam as clivagens internacionais mais amplas - como, por exemplo, durante a Guerra Fria, a clivagem Leste-Oeste teria servido para criar distintas preferências entre grupos de Estados que levavam a diferentes padrões de votação na $\mathrm{ONU}$-, ou seja, a ênfase seria na característica de que os Estados criariam preferências semelhantes com as dos EUA.

A segunda vertente destacaria a votação estratégica e as políticas feitas pelos EUA tanto para criar preferências comuns como para influenciar a votar com os norteamericanos, mais conhecido como compra de votos. Vale destacar que essas duas abordagens possuem uma lacuna, pois ignorariam a interação entre incentivos

\footnotetext{
${ }^{3}$ Esses resultados apoiam a observação de Keohane (1967, p. 17-8) sobre o uso de instrumentos extra-parlamentares de influência na ONU ser quase que exclusivamente concentrado nos EUA e na URSS.

${ }^{4}$ Ademais, as descobertas e a ausência de um modelo claramente específico sobre compra de votos tem tornado evidente a impossibilidade de descrever, de maneira concreta, a noção de que os EUA comprariam votos (RAI, 1980; KEGLEY; HOOK, 1991; WANG, 1999).
} 
institucionais domésticos dos governos para cooperar e políticas para suscitar cooperação (LAI; MOREY, 2006, p. 386).

Alguns estudiosos das Relações Internacionais tem tratado as votações da AGNU como um index das sinceras preferências dos Est. (GARTZKE, 2005; RUSSETT; ONEAL, 2001; STONE, 2004), enquanto outros tem utilizado correlações entre as votações na AGNU e a ajuda externa como uma evidência de compra de votos.

A explicação da semelhança de preferências, ou seja, o exame da semelhança de preferências em alinhamentos de votos na AGNU, tem sido feito por meio de análises de escalonamento e dimensionais para diferenciar padrões de votação e coalizões (KIM; RUSSETT, 1996; VOETEN, 2000). Esses estudos tem analisado diferentes subconjuntos de votos na ONU usando análise fatorial e outras técnicas para determinar pontos ideais para os Estados. Baseados nesses pontos ideais, as coalizões dentro a ONU poderiam ser determinadas e as dimensões sobre quais Estados se aliam, focando em fatores comuns aos Estados para explicar seus pontos ideais similares, chegando a conclusões de que, por exemplo, as democracias e os Estados mais ricos seriam mais propensos a votar com o Ocidente (KIM; RUSSETT 1996; VOETEN, 2000).

Por sua vez, o exame de incentivos estratégicos de Estados dentro da ONU focaria na capacidade dos EUA para usar ferramentas de política externa para alavancar a cooperação dos Estados com os EUA. Diferentemente da abordagem anterior, o nível de semelhança de preferência é menos importante; a cooperação, nesse caso, seria induzida por meio de políticas dos Estados como ajuda externa, que influenciaria as nações receptoras e as abriria a sugestão dos doadores. Sendo assim, quanto mais dependente um Estado é da ajuda norte-americana, mais próxima será a coincidência de votos com os EUA (WANG, 1999; LAI; MOREY, 2006, p. 388).

De acordo com esses estudos, a ajuda poderia servir não apenas para o auto interesse econômico dos doadores, mas também poderia ser usado para comprar apoio político dos receptores de ajuda. Mesmo que a situação geopolítica tenha sido modificada de maneira dramática desde o final da Guerra Fria, seria ainda mais ingênuo esperar que essa ajuda não fosse concedida por razões políticas (LANGHAMMER, 2004).

A luta contra o terrorismo e a oferta de doadores importantes, como Alemanha e Japão, para se tornarem membros permanentes do Conselho de Segurança fornecem exemplos de que considerações políticas poderiam ainda distorcer uma distribuição de ajuda baseada em necessidades. Conforme o estudo de Doucoliagos e Paldam (2007), 
fatores políticos ajudariam a explicar o surpreendente fraco impacto da população do país receptor no montante de ajuda recebida, pois pequenos receptores com desproporcionalmente maior poder nas organizações internacionais poderiam ser favorecidos pelos doadores, já que comprar a influência desses receptores é relativamente barato.

Um objetivo político que supostamente tem sido perseguido por meio da alocação de ajuda é afetar o voto dos receptores na AGNU. Existem indicativos de que os EUA e os países do G7 manteriam registros dos votos de Estados-membros da ONU e que o comportamento dos mesmos influenciaria as relações bilaterais, incluindo a ajuda (BARNEBECK ET AL., 2006).

O poder da AGNU poderia até ser limitado, e nem todas as decisões seriam importantes para os EUA, conforme apontado por autores já citados anteriormente. Ainda assim, existiria a ampla evidência de que o governo norte-americano confere algum peso ao resultado dos votos na AGNU. Segundo aponta um relatório do Departamento de Estado, em 2000, o comportamento de um país na ONU seria sempre relevante para suas relações bilaterais com os EUA, ponto que o Secretário de Estado sempre colocaria em suas cartas de instrução aos novos embaixadores norte$\operatorname{americanos}^{5}$ (BARNEBECK ANDERSEN ET AL, 2006).

Alesina e Dollar (2000), em seu estudo que busca apresentar os motivos que estariam por trás da alocação de ajuda por parte dos países doadores, utilizam como uma das variáveis analisadas a convergência na ONU para as principais potências EUA, Japão, França, Alemanha e Reino Unido -, chegando a conclusão de que esta seria significativa para todos esses atores.

Segundo os autores, a correlação entre as variáveis de amizade na ONU e os fluxos de ajuda poderia ser interpretada de duas maneiras: a ajuda seria utilizada para “comprar" apoio político na ONU, portanto, a ajuda compraria votos na ONU em favor do doador; a outra interpretação seria de que os votos na ONU seriam um indicador confiável das alianças políticas entre os países e que essas alianças determinariam os fluxos de ajuda (ALESINA; DOLLAR, 2000).

\footnotetext{
${ }^{5}$ Thacker cita um memorando do diretor do Programa Alimentos para Paz notando que "em momentos críticos da recente história mundial, os EUA compraram votos sutil e indiretamente para apoiá-los na AGNU" - Bennis (1997) aponta que "a influência na ONU vem na forma de coagir a organização a tomar uma ou outra posição, ou rejeitar alguma outra, ou pressionar um país ou países a votar de uma certa maneira na Assembleia Geral". (DREHER; NUNNEMKAMP; THIELE, 2008, p. 140)
} 
A priori, segundo Alesina e Dollar (2000), a segunda interpretação pareceria mais plausível, pois muitos votos na ONU não seriam importantes por si sós, do ponto de vista da política externa. Entretanto, não estria claro porque os países doadores se preocupariam em comprar esses votos, já que os padrões de votos seriam fortemente correlacionados com as alianças e as semelhanças de interesses políticos, econômicos e geopolíticos.

Os autores acreditam que melhor interpretação seria a de que os doadores favorecem seus amigos em seus desembolsos de ajuda, e uma observável demonstração de amizade seria os votos na ONU, o que implicaria que uma mudança exógena nos padrões de votação na ONU indicaria uma mudança no padrão das alianças geopolíticas que trariam uma mudança no padrão de ajuda (ALESINA; DOLLAR, 2000, p. 46)

De qualquer maneira, as duas interpretações acerca do significado das variáveis seriam consistentes com a visão de que a ajuda seria utilizada para propósitos estratégicos, não sendo, portanto, fácil desagregar econometricamente as duas interpretações, que correspondem a duas linhas de causalidade, a ajuda causa os votos na ONU ou os votos na ONU causam a ajuda (ALESINA; DOLLAR, 2000, p. 46).

Outros estudos focados na ONU tem encontrado evidências de que a ajuda externa dos EUA e de outros países desenvolvidos seria oferecida aos membros da organização para moldar seus padrões de votação na AGNU. Lay e Morey (2006) chegaram à conclusão de que os receptores que receberam os maiores níveis de ajuda econômica por parte dos EUA seriam mais propensos a votar com os norte-americanos na AGNU, apontando, portanto, a importância das instituições domésticas dos receptores em moldar a política externa de outros Estados. Portrafke (2009), por sua vez, conclui que a ideologia governamental explicaria parcialmente o quão similar seriam os votos dos membros da OCDE com os EUA na ONU, sendo assim, não teria como ser desprezada a importância dos fatores domésticos no comportamento de votação dos Estados nas organizações internacionais.

Portanto, a hipótese de que a votação na ONU afetaria a ajuda externa seria plausível, ao menos em votações-chaves que atraem atenção substancial dos doadores. Nesse sentido, o critério baseado na necessidade desempenharia um papel importante na determinação dos fluxos de ajuda, assim como objetivos políticos amplos como a promoção da democracia e os direitos humanos. Entretanto, reconhece-se que as agendas políticas dos doadores são críticas e poderiam levar as alocações de ajuda para 
longe da questão das necessidades (BOONE, 1996; ALESINA; DOLLAR, 2000; COLLIER; DOLLAR, 2002).

Os estudos focados especificamente na distribuição de ajuda tem demonstrado que a ajuda seria fortemente relacionada a interesses geopolíticos e preferências de política externa dos doadores (MAIZELS; NISSANKE, 1984; BOONE, 1996; CASHEL-CORDO; CRAIG, 1997; SCHRAEDER ET AL., 1998; ALESINA; DOLLAR, 2000; ALESINA; WEDER, 2002). Também existem pesquisas que comparam a alocação de ajuda de múltiplos doadores e encontraram que as razões para dar ajuda variam enormemente e seriam fortemente influenciadas, por exemplo, pelos laços coloniais dos doadores (SVENSSON, 1999; ALESINA; DOLLAR, 2000; ALESINA; WEDER, 2002; NEUMAYER, 2003).

Uma série de estudos tem achado associação entre as votações na AGNU e a ajuda externa dos EUA, mas os resultados tem sido diferentes. Rai (1980) encontra uma associação entre fluxos de ajuda e votação na AGNU, mas não consegue isolar o mecanismo causal, já Kegley e Hook (1991) não acham muita evidência empírica que ligue de maneira explícita entre a votação de importantes temas na AGNU e os desembolsos de ajuda nos anos 80 .

Segundo Wang (1999), esses resultados ambíguos teriam ocorrido, pois a maior parte dos trabalhos prévios não tinha distinguido entre votos identificados como importantes pelo Departamento de Estado norte-americano e os votos ordinários, algo que só teria sido possível após o governo Reagan, conforme explicitado anteriormente. Axel Dreher e Thiele (2008) tentam resolver esse problema e por meio da desagregação da ajuda em categorias e da utilização de uma variável instrumental conseguem encontrar e evidências em favor da hipótese de compra de votos.

Dessa maneira, os poucos estudos que propõem trazer evidência de compra de votos mostram uma conexão entre mudança nos fluxos de ajuda a um receptor dos EUA e a concordância nos votos (Wang, 1999). Entretanto, essas correlações podem ser explicadas de duas formas diferentes. De um lado, a sabedoria popular poderia estar correta, então a votação na ONU estaria associada à ajuda externa, já que a alocação de ajuda seria usada para recompensar ou punir países a votarem de determinadas maneiras. Por outro lado, a votação na ONU poderia não ser intrinsecamente importante para os doadores de ajuda, mas sim reflexo das sinceras preferências políticas dos membros da ONU. Sendo assim, qualquer relação entre votação na ONU e fluxos de ajuda poderia ser interpretada como evidência de que os doadores prefeririam contribuir 
com recursos a regimes com a mesma opinião e que tenham objetivos similares de política externa.

Existem estudos que também começaram a utilizar a variável "tipo de regime" para tentar explicar melhor essa ligação entre votos na ONU e alocação de ajuda externa. Lai e Morey (2006) examinam a influência do tipo de regime na capacidade das políticas estatais, como ajuda externa, em induzir a cooperação. Os autores partem da hipótese de que democracias e autocracias teriam incentivos domésticos divergentes para aumentar sua similaridade de votos em troca de assistência externa.

Dessa maneira, governos democráticos seriam mais propensos a votar conforme suas próprias preferências, o que faria com que uma redução na alocação de ajuda externa não influenciasse o seu voto, pois teria uma base de apoio das coalizões vencedoras e do eleitorado, além de ter a necessidade de prover bens públicos (BUENO DE MESQUITA ET AL., 2003). Já para os líderes autocráticos, a carência de legitimidade popular faria com que o governo dependesse do suprimento de bens privados aos grupos da elite (BUENO DE MESQUITA ET AL., 2003). Devido a isso, os líderes autocráticos seriam mais sensíveis à redução na ajuda, pois uma diminuição no fornecimento de fundos teria um amplo impacto na provisão de bens privados versus bens públicos, o que os levaria a serem mais suscetíveis a votar baseados nas relações de ajuda. Portanto, o tipo de regime desempenharia um importante papel para entender quando um Estado como os EUA poderia usar suas ferramentas de política para induzir a cooperação.

Lai e Morey (2006, p. 386) encontraram apoio para argumento de que o tipo de regime desempenharia um importante papel na determinação da efetividade da ajuda externa como uma ferramenta para ganhar votos na AGNU. Segundo os seus resultados, a hipótese de que a dependência da ajuda econômica e militar apenas levaria a níveis maiores de similaridade de votos seria válida apenas para as autocracias, pois os Estados democráticos dependentes da ajuda econômica ou militar teriam menos similaridade de votos com os EUA nos anos recentes.

Além da questão do regime de governo, também existiriam outras variáveis que influenciariam na probabilidade dessa ligação entre votação na ONU e alocação de ajuda por parte dos EUA. Carter e Stone (2011, p. 3) partem da hipótese de que os EUA puniriam ou recompensariam os receptores de forma muito diferente dependendo do seu tipo de regime, da orientação política do governo - esquerda ou direita -, nível de desenvolvimento e relação de aliança. Essas diferenças em credibilidade, segundo os 
autores, seriam a chave a para explicar a efetividade das tentativas dos EUA em influenciar os votos de outros Estados na AGNU.

Carter e Stone (2011, p. 30), ao final de seu estudo, rejeitam a hipótese de que as decisões de voto não seriam afetadas por estratégias posteriores de desembolso de ajuda, descartando, portanto, a ideia da vertente oposta à da compra de votos de que as votações na ONU seriam simplesmente uma sincera expressão das preferências dos Estados.

As votações na AGNU também tem sido utilizadas em estudos que buscam estabelecer uma associação entre as votações na ONU e a ajuda de vários doadores e instituições multilaterais (BARRO; LEE, 2005; OATLEY; YACKEE, 2004; THACKER, 1999; STONE, 2004).

Um dos estudos mais robustos acerca da participação nos programas do Fundo Monetário Internacional (FMI) atesta que o empréstimo do FMI seria significativamente moldado por preferências geopolíticas dos países que contribuem com os principais recursos, particularmente os EUA. Nessas pesquisas, a votação na ONU é reconhecida como uma importante variável de controle em estudos que buscam explicar a participação nesses os programas e como um instrumento útil para o controle selecionado de seus efeitos, já que a votação na ONU seria presumidamente exógena em relação ao resultado de variáveis como crescimento econômico (STEINWAND; STONE, 2008).

Thacker (1999) também utilizou a similaridade de perfil de votos de um país na AGNU em relação aos EUA para medir afinidade política aos EUA. O autor chega à conclusão de que o crescimento dessa convergência ao longo do tempo estaria associado à maior probabilidade de empréstimo do FMI. Barro e Lee (2005) também descobrem que os empréstimos do FMI são associados à similaridade nos padrões de votação dentro da ONU e os laços econômicos com os EUA. Todas essa evidências quantitativas apoiam a evidência de que muitos países não tem ido ao encontro dos critérios técnicos para qualificarem-se ao apoio recebido do FMI, mas desempenhariam um papel importante na política norte-americana, como Zaire e Filipinas durante a Guerra Fria, e Rússia, Ucrânia, Egito, Paquistão e Turquia durante os anos 90.

Outras pesquisas recentes tem focado nos votos designados como importantes pelos EUA para estudar a compra de votos. Andersen, Harr e Tarp (2006) assumem que esse alinhamento aos EUA em votações importantes da AGNU seriam uma concessão, e utilizariam esses votos para construir uma medida de concessões políticas que um país 
faria aos EUA, para, posteriormente, estimar a probabilidade de um país obter um empréstimo do FMI. Kilby (2010) utiliza uma medida similar em um recente estudo sobre o Banco Mundial.

Utilizando uma estratégia alternativa, Kuziemko e Werker (2006) restringem a interpretação de seus resultados empíricos ao focar nos membros temporários no CS, fato que criaria uma oportunidade temporária para oferecer valiosas concessões. As votações do Conselho seriam mais significativas que as da AGNU, logo os incentivos para comprar votos durante as crises seriam mais fortes. Os autores concluem que a ajuda dos EUA aumenta significativamente quando um país torna-se membro temporário e decai quando o mesmo passa a não fazer mais parte sai do CS.

Para Dreher, Sturm e Vreeland (2009), os empréstimos do FMI seriam um mecanismo por meio do qual os principais acionistas do fundo poderiam ganhar favores com os membros que estão votando no CSNU. No FMI, os votos são atrelados ao tamanho econômico, tendendo a ser controlado pelos países ricos em capital e empresta para o mundo em desenvolvimento. Já governança no CSNU também pende para os países desenvolvidos, mas os países pobres - a grande parte da população mundial - tem garantido uma voz única em importantes temas da segurança mundial, que poderiam ser importantes para os principais acionistas do FMI. Alguns países em desenvolvimento poderiam dar mais valor aos empréstimos do FMI do que a seus votos no CSNU, e os países desenvolvidos valorizariam os votos do CSNU mais do que os empréstimos fornecidos pelo FMI.

Portanto, alguns países em desenvolvimento estariam dispostos a comercializar seus votos no CSNU por empréstimos no FMI. Com preocupações econômicas severas e preocupações de segurança que são primariamente domésticas ou regionais, alguns governos do mundo em desenvolvimento poderiam dar mais atenção ao capital que o FMI poderia prover do que a temas de segurança considerados importantes pelos principais acionistas do $\mathrm{FMI}^{6}$ (DREHER ET AL., 2009).

\footnotetext{
${ }^{6}$ Para construir seu argumento, os autores consideram a natureza dos arranjos. Uma parcela do empréstimo é fornecida com a promessa de prestações continuadas sujeitas ao cumprimento de condições específicas de política econômica. Para alguns membros do CS, o cumprimento das condicionalidades do FMI e a contínua provisão de desembolsos de empréstimos podem depender de seus votos no conselho. Ao considerar a eleição do CSNU, o governo de um país em desenvolvimento deve pesar a probabilidade de que uma votação que venha a acontecer durante o seu mandato e que o governo possa votar contra os principais acionistas do FMI na ausência da sedução do empréstimo do FMI. Dada essa possibilidade, o governo deve pesar os custos e benefícios de votar contra seus interesses e receber o empréstimo ou votar sinceramente sem receber as parcelas do empréstimo. Em alguns casos, a barganha pode compensar isso.
} 
O que faria com que essa relação acontecesse seria o fato de que os principais acionistas do FMI se importam sobre como os países votam no CSNU e alguns países em desenvolvimento seriam mais propensos a trocar votos por empréstimos (DREHER et al., 2009, p. 752).

A literatura acerca da relação entre ajuda externa e votação na AGNU, apesar de enfatizar os países desenvolvidos e, principalmente, os Estados Unidos, seria importante, pois demonstraria que os Estados estariam dispostos a utilizar as mais diferentes ferramentas para influenciar o comportamento de votação dos países nos foros multilaterais e, assim conseguir importantes aliados para as suas demandas nessas instituições e assim ocupar um lugar de destaque no sistema internacional.

Entretanto, essa literatura não trataria dos determinantes para o apoio entre países em desenvolvimento nos organismos multilaterais e quais os instrumentos utilizados pelos mesmos para formar alianças que assegurem o atendimento a suas demandas nesses foros.

Portanto, essa tese, a partir da ideia da literatura de que os países "comprariam" o apoio de seus pares nas votações em organismos multilaterais, buscará, comprovar se isso também seria aplicado aos países em desenvolvimento que, nos anos recentes, tem aumentado o seu poder no sistema internacional e presença nas organizações internacional, tornando importante a investigação sobre a conquista de apoio por parte desses países nos foros multilaterais.

Boa parte da literatura acreditaria que o apoio seria conquistado a partir da ajuda externa, ou seja, que os países beneficiados pela mesma acabariam corroborando as demandas dos seus doadores no plano multilateral. Como os países em desenvolvimento tem uma capacidade de ajuda externa menor que os países desenvolvidos, uma das maneiras por meio das quais esse apoio poderia ser conquistado seriam os projetos de cooperação bilateral, já que o investimento seria menor que no caso da ajuda externa em dinheiro e também promoveria o desenvolvimento dos países beneficiados, o que, por sua vez, poderia fazer com que os mesmos passassem a votar de maneira semelhante aos seus benfeitores.

Outro elemento que poderia fazer com que os países se aproximassem - mas que não é muito investigado pela literatura sobre compra de votos - seria o comércio, pois o mesmo garantiria, assim como a cooperação ou a ajuda externa, o desenvolvimento e o crescimento econômico do país que recebesse maior atenção comercial, o que faria aumentaria a semelhança de posições no plano multilateral entre países cujo fluxo 
comercial aumente. Isso ocorreria não apenas pelo conhecimento mútuo provocado por essa intensificação, mas também pelo aumento da interdependência entre parceiros comerciais.

Essa tese, portanto, busca investigar se a literatura acerca da compra de votos, basicamente dedicada ao estudo dos países desenvolvidos, poderia ser aplicada também para a análise do apoio multilateral entre países em desenvolvimento, ou seja, se esses países, assim como os países desenvolvidos conseguiriam, por meio de determinadas estratégias, influenciar o comportamento de outros Estados nos organismos multilaterais e assim aumentar o seu peso no sistema internacional.

\section{CAPÍTULO II - AS RELAÇÕES BRASIL-ÁFRICA NOS ANOS RECENTES (1995-2010):}

Esse capítulo tem como objetivo principal analisar as relações do Brasil com o continente africano, entretanto para que essa análise possa ser feita de maneira mais 
completa, faz-se necessário localizar e apontar o peso da política africana no cenário mais amplo das políticas externas dos dois governos a serem analisados - Fernando Henrique Cardoso (FHC) e Luís Inácio Lula da Silva (Lula). Dessa maneira, esse capítulo está dividido em três seções: a primeira, partir da análise de elementos como viagens presidenciais e fluxo comercial, as regiões de interesses para as políticas exteriores dos dois governos analisados para, dessa maneira, ser possível apontar o peso dispensado ao relacionamento com regiões em desenvolvimento. A segunda apresentará as diretrizes gerais da política exterior de cada presidente em relação ao continente africano e, por fim, a terceira apresentará os dados relativos às duas variáveis independentes escolhidas - comércio e cooperação - no tocante às relações BrasilÁfrica.

\subsection{As regiões de interesse das políticas exteriores de FHC e Lula em números:}

A partir do governo Lula, houve um direcionamento para o relacionamento com os países do Sul, principalmente os países latino-americanos e africanos, por meio da ampliação ou reativação dos contatos com parceiros não-tradicionais nessas duas regiões, o que poderá ser verificado por meio de dados como viagens presidenciais, corrente de comércio e cooperação.

Uma das possibilidades para esse comportamento externo seria a crença por parte dos formuladores da política exterior do governo Lula de que por meio da intensificação dos contatos com países em desenvolvimento o Brasil conseguiria formar alianças com os mesmos para fazer com que as suas demandas no plano internacional como desenvolvimento mais igualitário e uma vaga de membro permanente no Conselho de Segurança da ONU - pudessem obter maior visibilidade e apoio por parte dos países do Sul, principalmente nos foros multilaterais. Ademais, esse governo teria, devido sai identificação partidária, a crença de que os países em desenvolvimento, ao se unirem, teriam a capacidade de influenciar nos assuntos internacionais, principalmente, nas organizações multilaterais em que são maioria.

Essa mudança de estratégia pode ser verificada, primeiramente, pela análise dos destinos das viagens presidenciais bilaterais. Ocorre, entre os dois governos, a modificação nesses destinos, exceto em relação à região sul-americana e europeia que receberam forte atenção pelos dois presidentes, já que as mesmas teriam destaque nas 
políticas exteriores dos governos FHC e Lula. A alteração é perceptível quando analisase os destinos a partir da clivagem Norte-Sul, enquanto FHC teve uma agenda mais equilibrada de viagens, com 48 viagens para o Norte $(41,7 \%$ do total) e 67 para o Sul $(58,2 \%)$, Lula claramente privilegiou o Sul em suas visitas internacionais, viajando 47 vezes para países do Norte (26,1\% do total) e 123 para países do Sul (68,3\% do total), destacando-se os países africanos ${ }^{7}$ e latino-americanos, que receberam $62 \%$ do total de viagens presidenciais bilaterais (FONTE: GARCIA, 2005; MRE, 2010, p.9).

Figura 1 - Visitas bilaterais por região

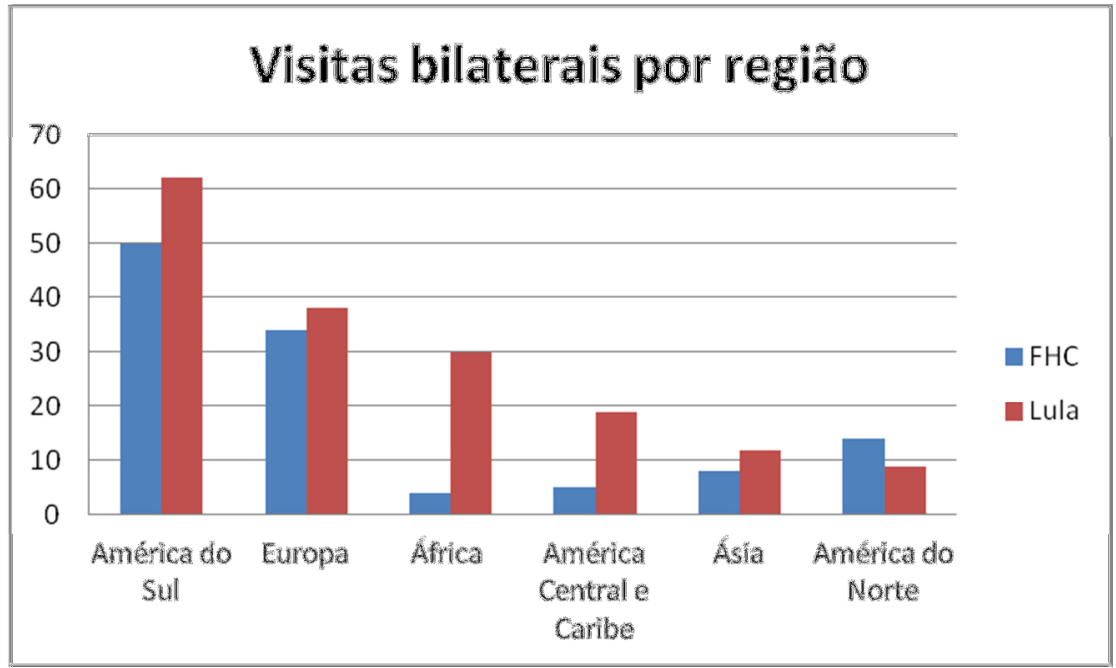

Elaboração própria. Fonte: GARCIA, 2005; MRE, 2010, p. 9.

Essa diversificação de parceiros também ocorre no intercâmbio comercial, acontecendo um aumento das exportações brasileiras, que passaram de US\$ 61,68 bilhões, em média, no governo FHC para US\$133,92 bilhões ${ }^{8}$, em média, no governo seguinte, aumentando cerca de $117 \%$ entre os dois governos quando comparados os valores totais das exportações ${ }^{9}$.

Ao analisar os destinos das exportações brasileiras, assim como em relação ao número de viagens presidenciais, percebe-se um aumento das exportações para o Sul, ultrapassando, no período, aquelas destinadas ao Norte. Ademais, ocorre também uma

\footnotetext{
${ }^{7}$ Ao analisar a agenda de viagens presidenciais à África, percebe-se a diversificação da relação com o continente africano, sendo que a diferença de viagens presidenciais àquela região, entre Lula e seu antecessor, seria bastante elevada, já que Lula teria visitado, em seus dois mandatos, cerca de 29 países. Ademais, ainda percebe-se uma relevância maior de parceiros tradicionais, como Moçambique, Angola e África do Sul, que receberam mais de uma visita presidencial, enquanto seu antecessor visitou, ao longo de seus dois mandatos, apenas dois países (Angola e África do Sul) (Fonte: MRE, 2010, p.1)

${ }^{8}$ Todos os valores foram deflacionados tendo como base ano de 2005.

${ }^{9}$ No governo FHC, as exportações totais atingiram US\$ 493,45 bilhões FOB (ano base 2005) enquanto no governo Lula, as mesmas totalizaram US\$ 1.071,40 bilhões FOB (ano base 2005) (FONTE: MDIC).
} 
mudança nos destinos das exportações, sendo que o volume de exportações aos países do Sul vai, ao longo, do governo Lula, ultrapassando as exportações ao Norte, crescendo $276 \%$ para os primeiros e $76 \%$ para os segundos.

Figura 2 - Evolução do Destino das Exportações Brasileiras

\section{EVOLUÇÃO DO DESTINO DAS EXPORTAÇÕES BRASILEIRAS (US\$ BILHÕES -ANO BASE 2005)}

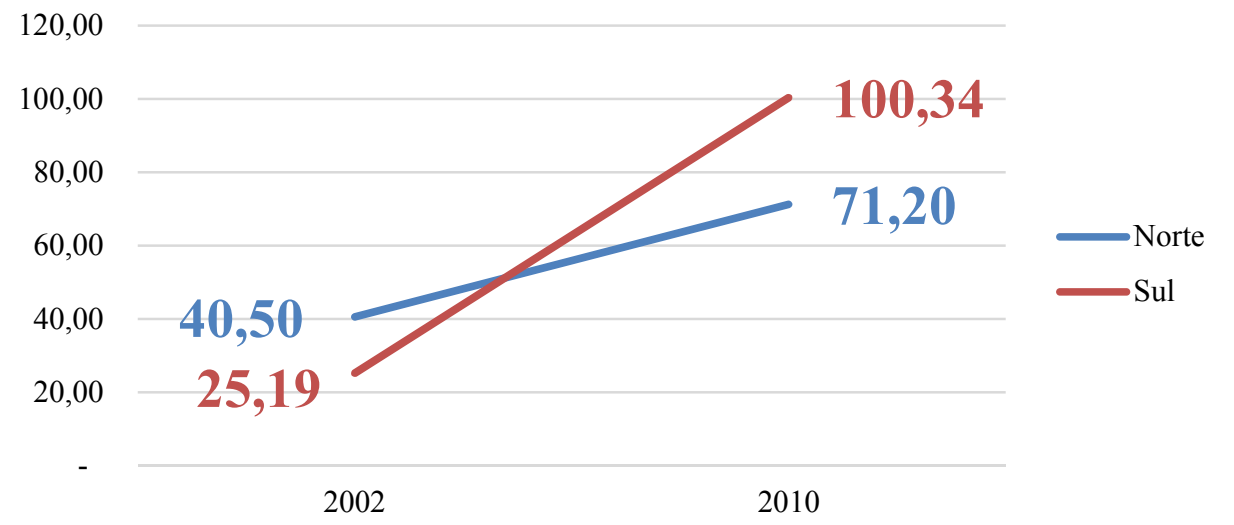

Elaboração própria. Fonte: MDIC

Entretanto, essa mudança no perfil das exportações brasileiras ainda é lenta, pois a média da participação do Sul nas exportações brasileiras, no governo Lula é bastante parecida com participação do Norte, além de não ter crescido muito em relação ao governo anterior, passando de $39,10 \%$ no governo FHC para $49,49 \%$.

Figura 3 - Participação das regiões nas exportações brasileiras 


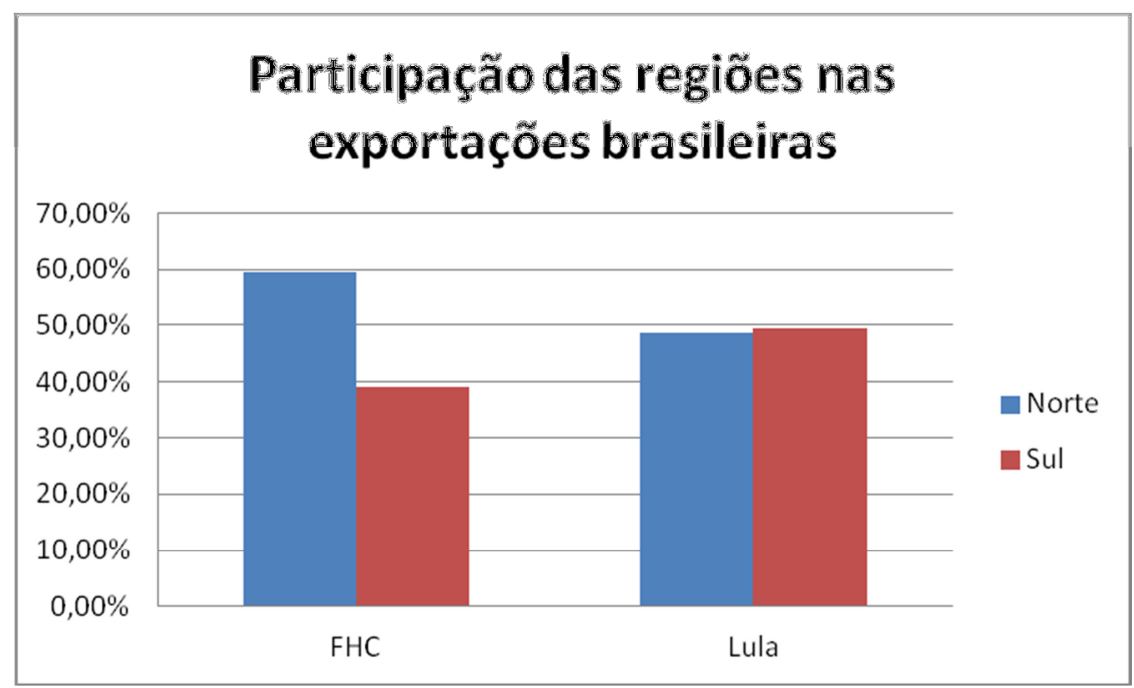

Elaboração própria. FONTE: MDIC

Ao analisar os mercados de destino das exportações brasileiras, percebe-se que o aumento das exportações para o Sul deveu-se, principalmente, ao aumento nas exportações para América Latina e China e ao recuo nas exportações para o mercado norte-americano.

Figura 4 - Destino das Exportações Brasileiras por Governo

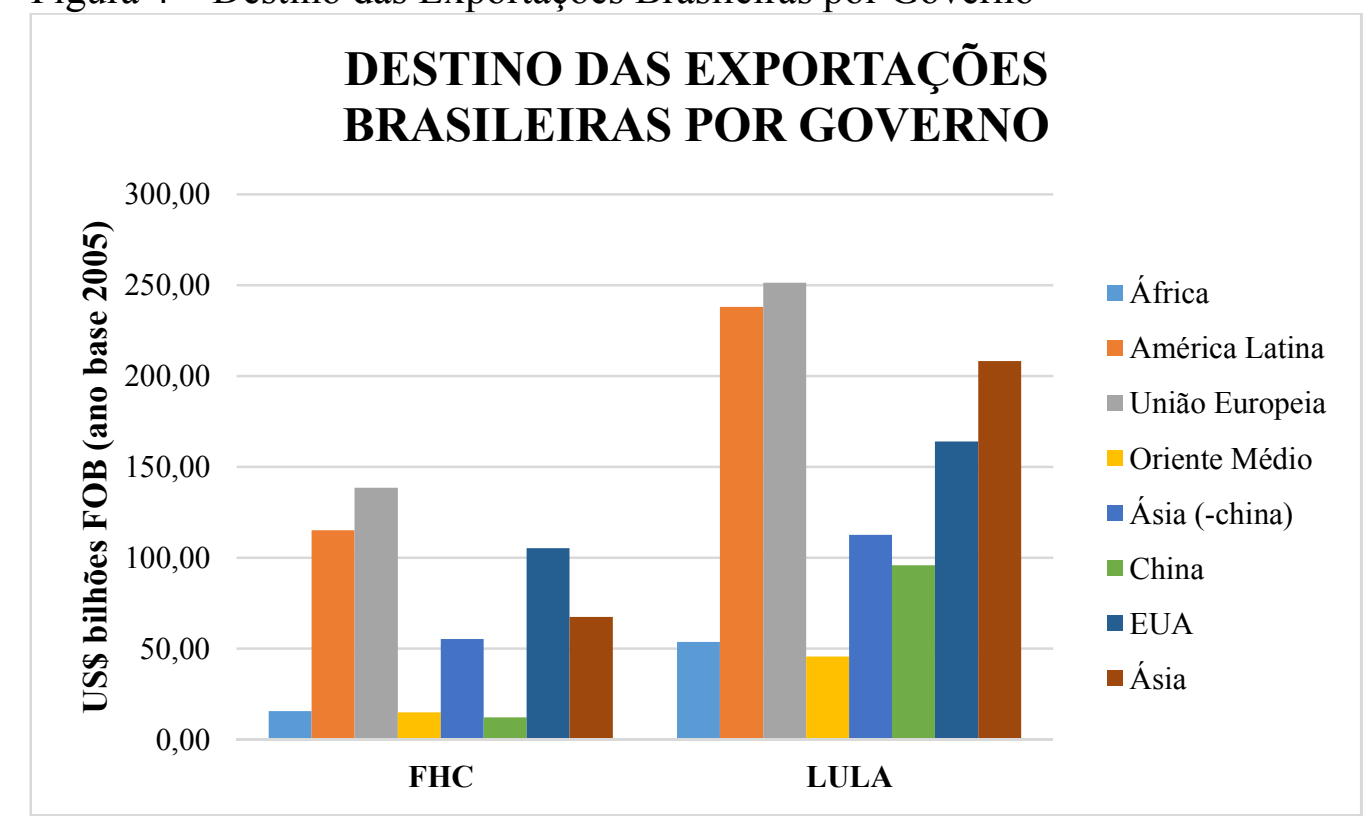

Elaboração Própria. Fonte: MDIC

Entretanto, ao examinar de maneira mais detida esses dados, percebe-se que a participação desses países não foi muito modificada, ou seja, a alteração é marginal, sendo que os mercados europeu e norte-americano ainda continuariam sendo bastante relevantes para as exportações do País.

Figura 5 - Participação dos mercados nas exportações brasileiras 


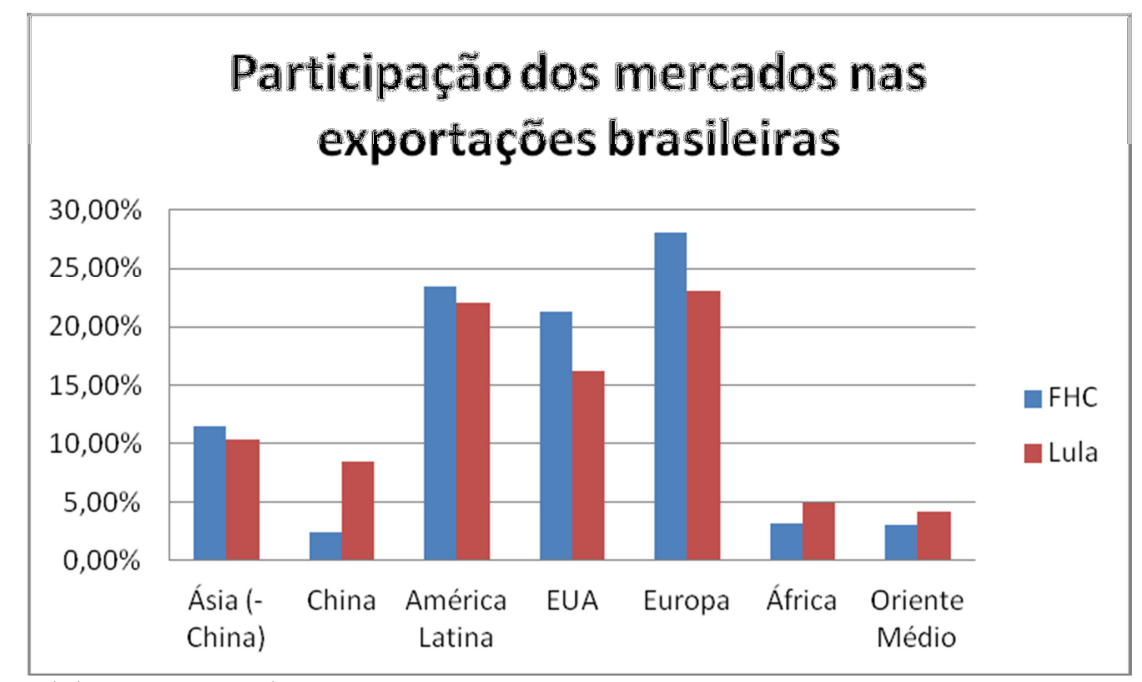

Elaboração própria. FONTE: MDIC

No caso das importações, o movimento é semelhante ao das importações, mas em ritmo mais lento que aquele apresentado no caso das exportações. As importações brasileiras cresceram 62 entre os dois governos, passando, em média, de US\$ 63,26 bilhões (ano-base 2005) no governo FHC, para US\$ 102,45 no governo Lula ${ }^{10}$.

De maneira semelhante às exportações, também ocorre uma modificação nas origens das importações brasileiras, ocorrendo um aumento das importações provenientes do Sul e uma diminuição daquelas vindas do Norte, apesar desse aumento não ser suficiente para ultrapassar as importações provenientes dos países em desenvolvimento. As importações oriundas do Sul passam de US\$ 173,9 bilhões (anobase 2005) no governo FHC para US\$ 386,95 bilhões (ano-base 2005) no governo seguinte, ou seja, um aumento de $123 \%$ entre os dois governos. Já as importações originadas do Norte passam de US\$ 333,39 bilhões (ano-base 2005) governo FHC para US\$ 437,45 bilhões (ano-base 2005) no governo Lula, ou seja, um incremento de $31 \%$ entre os governos FHC e Lula.

\footnotetext{
${ }^{10}$ As importações totais brasileiras passaram de US\$ 506,8 bilhões (ano-base 2005) no governo FHC para US\$ 819,6 bilhões (ano-base 2005) no governo Lula.
} 
Figura 6 - Evolução das origens das importações brasileiras

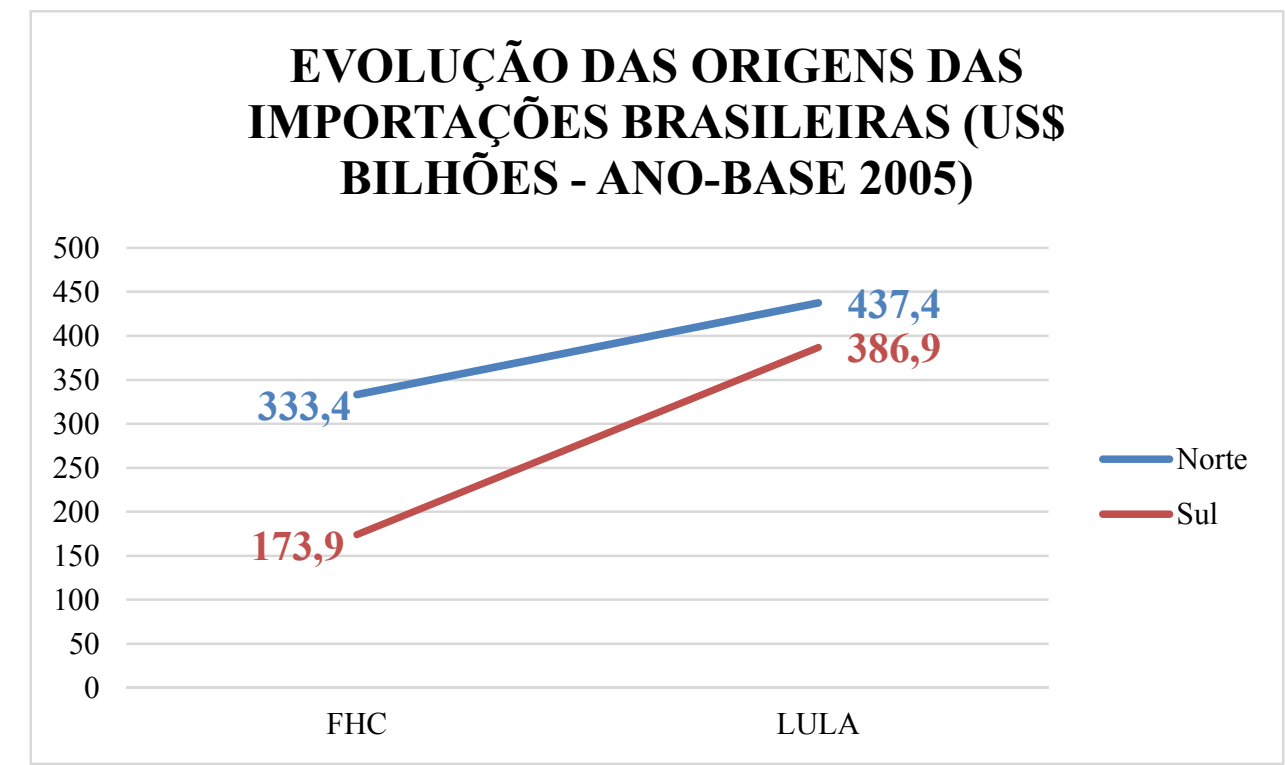

Fonte: AliceWeb. Elaboração Própria.

Figura 7 - Participação nas importações brasileiras por região

\section{PARTICIPAÇÃO NAS IMPORTAÇÕES BRASILEIRAS POR REGIÃO}

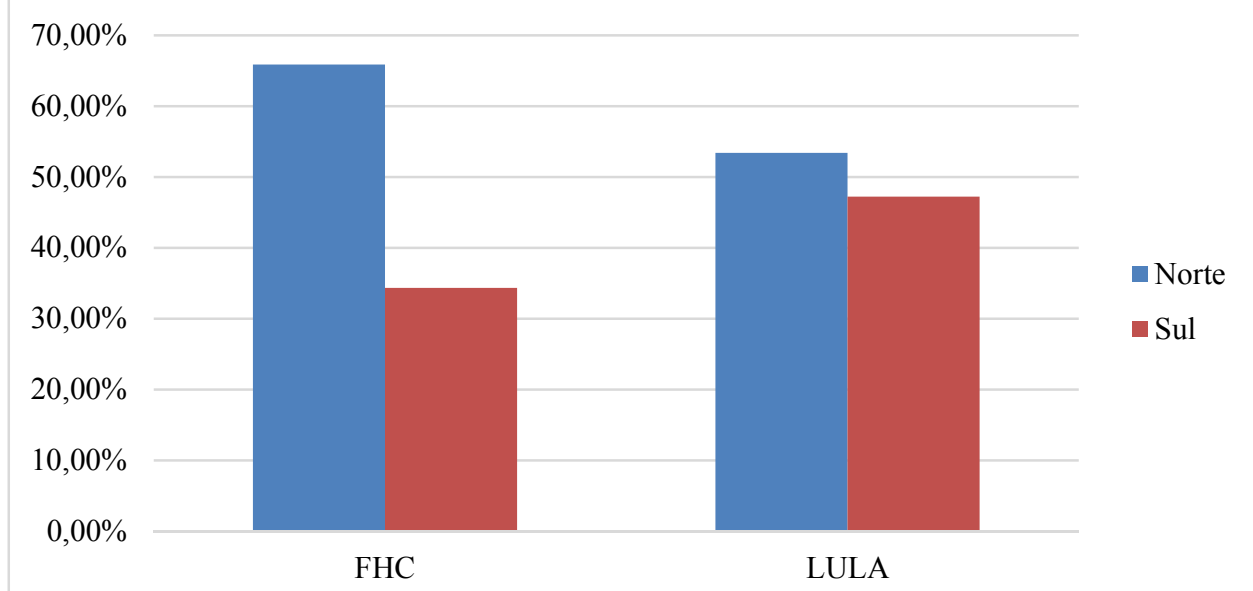

Fonte: AliceWeb. Elaboração Própria.

Quanto às origens das importações brasileiras, percebe-se um aumento em praticamente todos os mercados, exceto Estados Unidos que permaneceu praticamente estável e o Oriente Médio em que houve uma queda bastante acentuada entre os dois governos, que saiu da primeira posição no governo FHC e passou a ocupar o último lugar no governo seguinte. Essa queda é explicada devido à diminuição das importações de petróleo no governo Lula, devido melhorias na exploração e produção de petróleo no território nacional. 
As importações que mais crescem são aquelas oriundas do continente asiático, em grande medida devido à China que, assim como no caso das exportações, é responsável por boa parte das importações vinda da Ásia.

Figura 8 - Origens das importações por mercado

\section{ORIGENS DAS IMPORTAÇÕES BRASILEIRAS POR MERCADO (US\$ BILHÕES - ANO BASE 2005)}

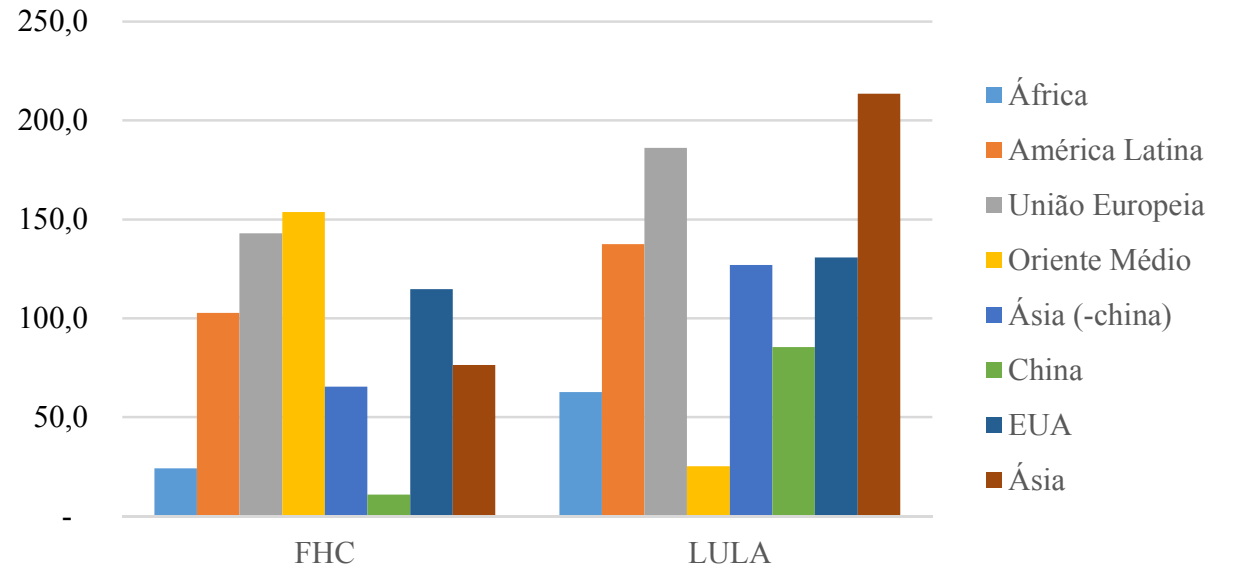

Fonte: AliceWeb. Elaboração Própria.

Ao analisar a participação das regiões nas importações totais, percebe-se uma queda em praticamente todos os mercados, exceto Ásia - em grande medida devido à China - e África, o que por sua vez, explicaria o aumento das importações originadas dos países em desenvolvimento apontadas nos dois gráficos anteriores. 
Figura 9 - Participação dos mercados nas importações totais brasileiras

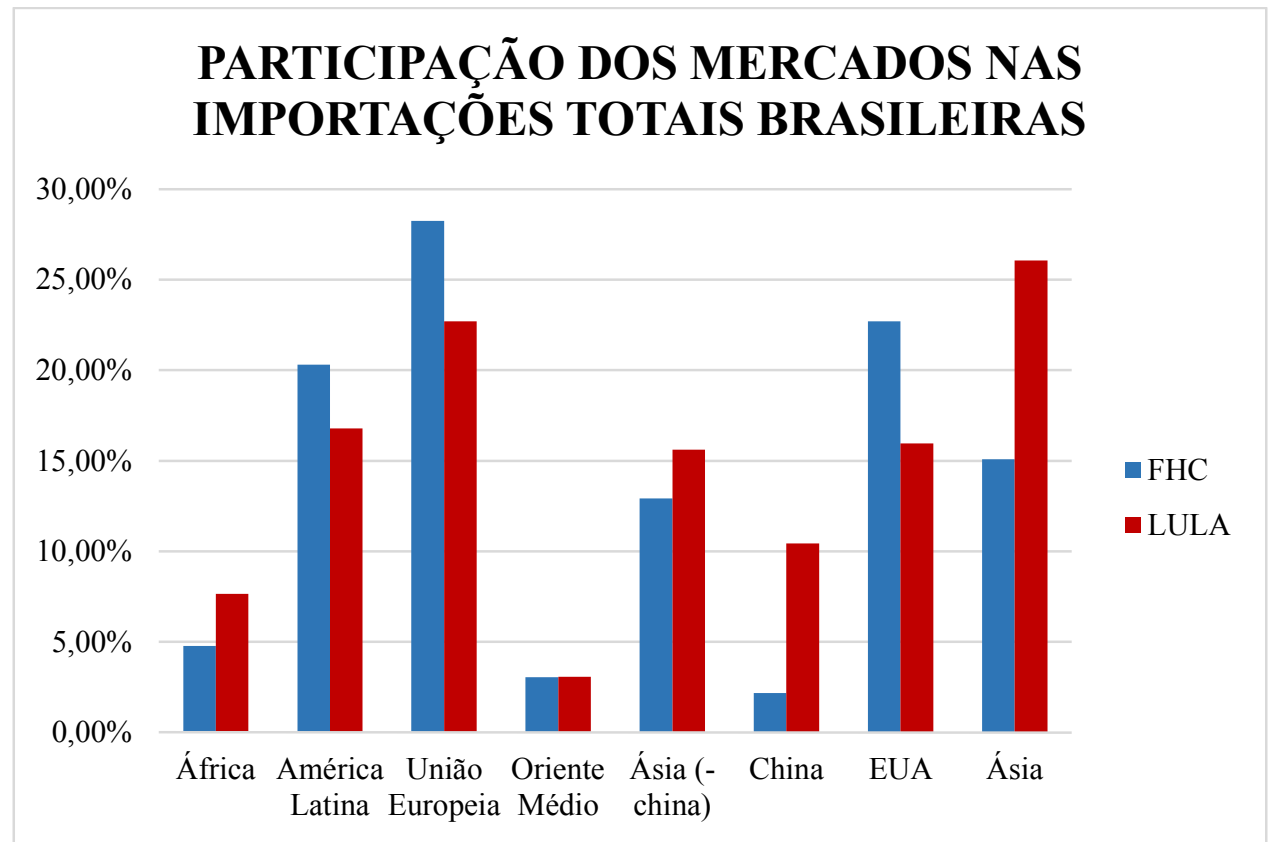

Fonte: AliceWeb. Elaboração Própria.

Os dados colhidos até o presente momento confirmam hipótese de que teria ocorrido uma relativa modificação na política exterior, com a intensificação de contatos com os países do Sul, o que poderia ser utilizado como uma estratégia para aumentar o poder de barganha do Brasil no sistema internacional. Entretanto, cabe ressaltar que boa parte dessa mudança deve-se à ascensão chinesa que aumentou, entre os dois governos, a sua influência internacional, principalmente no plano comercial.

\subsection{As linhas da política africana em perspectiva comparada}

Após séculos de intensos contatos entre o Brasil e o continente africano, devido ao tráfico de escravos ou à influência cultural dos escravos africanos na cultura brasileira, as relações entre os dois lados do Atlântico foram reduzidas por mais de um século.

O relacionamento com a África só foi retomado a partir da Política Externa Independente (PEI) (1961-1964), em que foi definida uma política dirigida aos países africanos, por meio do posicionamento brasileiro a favor da descolonização, principalmente foros multilaterais, bem como da identificação de demandas comuns entre os dois parceiros em relação ao desenvolvimento econômico, à proteção dos 
preços das commodities - com vistas a evitar o agravamento da deterioração dos termos de troca que afetava as exportações de ambos - à industrialização e ao desejo de paz ${ }^{11}$.

Esse renascimento da política africana foi consolidado apenas no governo Geisel (1974-1979), por meio do Pragmatismo Responsável, passou-se do nível do discurso marca da PEI - para atitudes mais concretas no tocante ao relacionamento com a África $^{12}$. $\mathrm{O}$ continente era visto pelos formuladores da política exterior brasileira como uma área-chave para os interesses econômicos e estratégicos nacionais, tanto que houve, nesse governo a instalação da primeira companhia brasileira na África Sub-sahariana.

Entretanto, nos anos 80, devido à crise vivida pelo modelo de desenvolvimento brasileiro baseado na substituição de importações e na diversificação de parceiros estrangeiros, ao consequente endividamento externo do Brasil e da maior parte dos países africanos e aos conflitos étnicos que irromperam na África após o fim da bipolaridade, houve uma certa reversão no relacionamento com o continente africano. Ainda assim, houve iniciativas específicas, como a primeira visita de um presidente brasileiro ao continente em 1983, quando o presidente João Batista Figueiredo viajou para Nigéria, Senegal, Guiné-Bissau e Cabo Verde.

Nos anos 90, as relações Brasil-África entraram em declínio, o que pode ser verificado pelo comércio que retornou aos níveis das décadas de 50 e 60 . Na mesma década, o comércio entre o Brasil e a África não teria chegado aos $2 \%$ das relações comerciais brasileiras, depois de ter alcançado os $10 \%$ na década anterior (SARAIVA, 2010).

Esse declínio deve-se a conjuntura desfavorável para os dois parceiros. O continente africano estava cada vez mais marginalizado no sistema internacional, devido à continuidade do endividamento externo e dos programas de ajuste do FMI, às epidemias e aos conturbados processos de transição para o regime democrático que, muitas vezes levaram à irrupção de violentos conflitos civis.

Por sua vez, o Brasil também passava pela consolidação do seu processo de democratização, pela crise inflacionária, bem como pela abertura comercial da economia brasileira. Essas mudanças fizeram com que se privilegiasse o relacionamento

\footnotetext{
${ }^{11}$ Essa postura seria considerada um divisor de águas na política externa do Brasil para o continente africano, já que os governos anteriores adotaram uma atitude de alinhamento ou, ao menos, não confrontação com as potências coloniais. Essa modificação na orientação internacional brasileira em relação ao continente africano iria ao encontro das novas demandas criadas pelo processo de industrialização iniciado nas décadas anteriores.

${ }^{12}$ Dentre essas atitudes, estaria o reconhecimento por parte do governo brasileiro - antes que qualquer outro governo ocidental - do Movimento pela Libertação de Angola (MPLA), de ideologia comunista, como o governo legítimo de Angola, em 1975.
} 
com o mundo desenvolvido em busca de conquistar a credibilidade e, consequentemente, os investimentos internacionais necessários para a transição econômica do país.

Naquele momento, os formuladores da política africana estariam divididos entre nostálgicos e catastrofistas. O primeiro grupo enfatizava as responsabilidades históricas - destacando os laços culturais brasileiros e a dívida histórica brasileira com a África -, comparando os anos 90 com os anos 70, acreditando que os últimos teriam sido melhores para a atuação internacional do país. Já, o segundo grupo - dominante ressaltava a crise aguda vivida pelos países africanos, o que tornaria impossível o diálogo com os mesmos (PIMENTEL, 2000).

A partir da visão catastrofista dominante, a seletividade daria o tom da política externa na década de 90, com destaque para o relacionamento com a África do Sul parceiro tradicional do Brasil no continente -, Angola, os países da Zona de Paz e Cooperação do Atlântico Sul (ZOPACAS) e da Comunidade de Países de Língua Portuguesa (CPLP). Para Pimentel (2000), essa estratégia seria a mais eficaz naquele momento devido à diversidade de países no continente africano, o que impediria uma política geral para toda a região.

A seletividade, portanto, será estratégia escolhida por FHC (1995-2002). Entretanto, não existe uma política externa uniforme entre os dois mandatos. Em seu primeiro governo, a África ocuparia um lugar modesto na política exterior brasileira, tanto que em seu discurso de posse, Fernando Henrique faz apenas uma menção à região, enfatizando, principalmente, o relacionamento com a África do Sul pósapartheid (CARDOSO, 1995). Já no segundo mandato, ocorre uma certa inflexão, que será aprofundada no governo posterior.

Portanto, a atuação brasileira no continente africano estaria confinada, em FHC, à tradicional seletividade da política exterior nacional nos anos 90. Apesar disso, o governo reconhece a relativa importância da África para a estratégia de inserção internacional do Brasil, que estariam em consonância com as seguintes razões, conforme apontado pelo chanceler Luiz Felipe Lampreia (1995)

\footnotetext{
“ a) a proximidade relativa entre o Brasil e a África e o fato de que grande parte do continente compartilha conosco o Atlântico, uma base física que também facilitou as relações comerciais no passado; b) a condição de país em desenvolvimento que, em diferentes gradações, o Brasil compartilha com a totalidade do continente africano; c) a complementaridade existente entre a economia brasileira e as economias africanas, que era forte no passado e
} 
deveria ser reavaliada no presente; d) a importância da África como parceira internacional, com cinquenta países, diversas culturas e muitas interfaces geográficas - com o Mediterrâneo, o Oriente Médio, a península Ibérica, o Atlântico Sul e o oceano Índico; juntamente com um peso político próprio, a extensa e variada África, mesmo enfrentando problemas, oferece janelas de oportunidades para parcerias com países em desenvolvimento; e) a grande semelhança de condições físicas, climáticas e sociais entre o Brasil e muitos países africanos, gerando uma importante 'identidade regional' em termos de desenvolvimento tecnológico e adaptabilidade de técnicas para os vários tipos de ambientes tropicais que o Brasil compartilha com seus parceiros africanos". (LAMPREIA, 1995, p. 205)

Segundo Saraiva (2002, p. 10-1), o distanciamento em FHC estaria ligado a dois elementos, de um lado, à ênfase na abertura econômica, no ajuste fiscal, na redução dos investimentos públicos e nas privatizações como vetores da política externa e, de outro, à crença kantiana e idealista da diplomacia brasileira de que as grandes potências reformariam o sistema multilateral de acordo com as novas forças em ascensão, o que levaria o Brasil à modernidade.

A inflexão no segundo mandato de FHC estaria ligada à crise do Real e à modificação da postura do presidente em relação à globalização que, em seu discurso, passa de "inevitável" para "assimétrica", o que aumentaria, em tese, a convergência do Brasil com Estados africanos nos foros multilaterais, principalmente os econômicos ${ }^{13}$. Ademais, há o crescimento de cooperação na área de políticas públicas, especialmente quando o Brasil inicia o contencioso pela quebra de patentes de medicamentos para a AIDS, epidemia que assolava a África Austral.

Dentre as ações empreendidas estariam a participação mais ativa do em missões da $\mathrm{ONU}^{14}$, em sua maioria no continente africano e a assinatura do Acordo Quadro África do Sul-Mercosul. Isso demonstra que, apesar do afastamento em relação à África, teriam ocorrido, ainda que esparsos, contatos com a região.

Esses contatos podem ser confirmados pela participação do continente africano no comércio brasileiro que não teria sofrido grandes alterações no governo seguinte, conforme demonstraram os dados relativos às participações por mercado, bem como por meio de projetos de cooperação técnica com diferentes países africanos.

\footnotetext{
${ }^{13} \mathrm{Na}$ OMC, por exemplo, o Brasil apontava que o principal desafio da organização era a promoção da integração do Sul aos fluxos internacionais de comércio, para que alcançassem os objetivos de estabilização e crescimento econômico, em um mundo globalizado que, muitas vezes, apresentava graves riscos e obrigava a um ajustamento com profundas consequências sociais. Os países da OMC teriam que esforçar-se para corrigir as assimetrias e promover o desenvolvimento econômico de maneira equânime (LAMPREIA, 1999, p. 273).

${ }^{14}$ Deve-se ressaltar que essa participação mais ativa nas missões de paz da ONU guardaria estreita relação com a campanha empreendida pelo Brasil para tornar-se membro permanente do Conselho de Segurança dessa organização, um importante objetivo da política externa multilateral do governo FHC.
} 
Com a ascensão de Lula à presidência da República, em 2003, a política africana ganhará destaque na política exterior brasileira. Tal proeminência estaria relacionada à estratégia de incrementar o relacionamento com os países em desenvolvimento com vistas à consecução do objetivo-chave nacional - o desenvolvimento. Dessa maneira, é natural que o relacionamento brasileiro com a África - formada por PEDs e países de menor desenvolvimento relativo (PMDRs) - ganhe relevância durante esse governo.

Assim como nos anos 90, cabe ressaltar que a conjuntura tanto no ambiente doméstico africano como brasileiro teriam contribuído para o reforço das relações Brasil-África no governo Lula. No início dos anos 2000, o continente africano começou a experimentar taxas relativamente altas de crescimento assim como com o fim de muitos conflitos civis, foi possível levar a cabo um bem-sucedido processo de reestruturação dos Estados e das sociedades africanas, despertando assim o interesse de diversas potências sobre o continente, principalmente as emergentes.

O Brasil, naquele momento, também crescia economicamente, tornando a África uma região atraente para um país que estaria mais maduro do ponto de vista econômico.

Nesse sentido, o reconhecimento do problema racial no Brasil e a introdução de políticas de ação afirmativa bem como uma política externa voltada ao estabelecimento de parcerias estratégicas com os países do Sul tiveram ressonância no continente africano (LOPES, 2007, p. 5).

Lula, já em seu discurso de posse, aponta para uma cooperação mais ampla com a África, restrita não apenas ao relacionamento econômico-comercial (SILVA, 2003).

\footnotetext{
"Reafirmaremos os laços profundos que nos unem a todo o continente africano e a nossa disposição de contribuir ativamente para que ele desenvolva as suas enormes potencialidades" (SILVA, 2003, p. 4).

"Nosso objetivo com a África é muito mais de cooperação direta do que propriamente de criar uma estratégia global. Evidentemente tudo se junta de alguma maneira e, (...). Nós temos interesses também nos países de língua portuguesa.” (AMORIM, 2003).
}

Ao defenderem-se das críticas ao aprofundamento das relações Brasil-África, tanto o presidente quanto o seu chanceler afirmaram que esse relacionamento estaria baseado em interesses concretos. A conotação não seria nem paternalista, ao reproduzir o discurso de livrar-se da culpa pelo passado colonial, nem de exploração, com vistas apenas à exploração das grandes reservas de recursos naturais, mas sim a construção de uma verdadeira parceria (SILVA, 2009). 
Essa aproximação, portanto, estaria concentrada em interesses estratégicos e econômicos, sendo que um de seus principais objetivos seria a apoiar a projeção mundial brasileira.

Dessa maneira, a principal diferença no relacionamento brasileiro com a África entre FHC e Lula está no número de parceiros e contatos. Enquanto FHC privilegiou as relações com os países pertencentes à Comunidade de Países de Língua Portuguesa e com a África do Sul, Lula teria ampliado os contatos com parceiros não-tradicionais na região, conforme será demonstrado pela corrente de comércio, abertura de embaixadas e viagens presidenciais. Sendo assim, a aproximação em FHC teria sido seletiva enquanto em Lula foi diversificada.

A reativação da política africana do Brasil, no governo Lula, ampliou o raio de atuação a outros países além daqueles pertencentes à CPLP e da África do Sul, prioridades no governo anterior. Esse ajuste pode ser percebido em diversos aspectos como as viagens presidenciais, mudanças estruturais no âmbito do Itamaraty e da representação diplomática e o intercâmbio comercial.

Os dois chefes de Estados em questão utilizaram-se, de forma intensa, da diplomacia presidencial, realizando inúmeras viagens a diversos países. No caso do continente africano, a diferença de viagens presidenciais àquela região é bastante elevada e aponta a seletividade e a diversificação entre os dois governantes. Enquanto FHC, visitou, em suas 4 passagens pelo continente, apenas dois países (Angola e África do Sul), Lula, em suas 34 viagens, visitou cerca de $29^{15}$ países. Apesar dessa mudança, ainda pode-se perceber uma relevância maior de parceiros tradicionais, como Moçambique, Angola e África do Sul, que receberam mais de uma visita presidencial, apesar de que o nosso principal parceiro comercial em importações, a Nigéria, tenha recebido apenas uma visita. Lula esteve presente em cúpulas de organismos regionais africanos como a União Africana, a CPLP, a Nova Parceria para o Desenvolvimento da África (NEPAD), Comunidade Econômica dos Estados da África Ocidental (Cedeao) e Comunidade para o Desenvolvimento da África Austral (SADC), além da realização ao longo de seus mandatos, desde 2006, da Cúpula de chefes de Estado da África e da América do Sul (MRE, 2010, p. 1).

\footnotetext{
${ }^{15}$ Os países visitados pelo presidente Lula em dois mandatos foram: África do Sul (3 vezes); Líbia (3 vezes); Moçambique (3 vezes); Angola (2 vezes); Argélia (1 vez); Benin (1 vez); Botsuana (1 vez); Burkina Faso (1 vez); Cabo Verde (1 vez); Camarões (1 vez); Congo (1 vez); Egito (1 vez); Gabão (1 vez); Gana (1 vez); Guiné-Bissau (1 vez); Guiné Equatorial (1vez); Namíbia (1 vez); Nigéria (1 vez); Quênia (1 vez); São Tomé e Príncipe (1 vez); Senegal (1 vez); Tanzânia (1 vez) e Zâmbia (1 vez) (MRE, 2011, p. 4).
} 
No que tange à estrutura do Itamaraty, os ajustes também são claros. No governo FHC, ocorreu o fechamento das embaixadas brasileiras em Camarões, na República Democrática do Congo e na Tanzânia. Já no governo Lula, ao contrário, o número de embaixadas brasileiras na África dobrou, passando a 34, destacando a reabertura das três embaixadas supracitadas e a abertura de novas representações ${ }^{16}$.

Figura 10 - Embaixadas reabertas na África

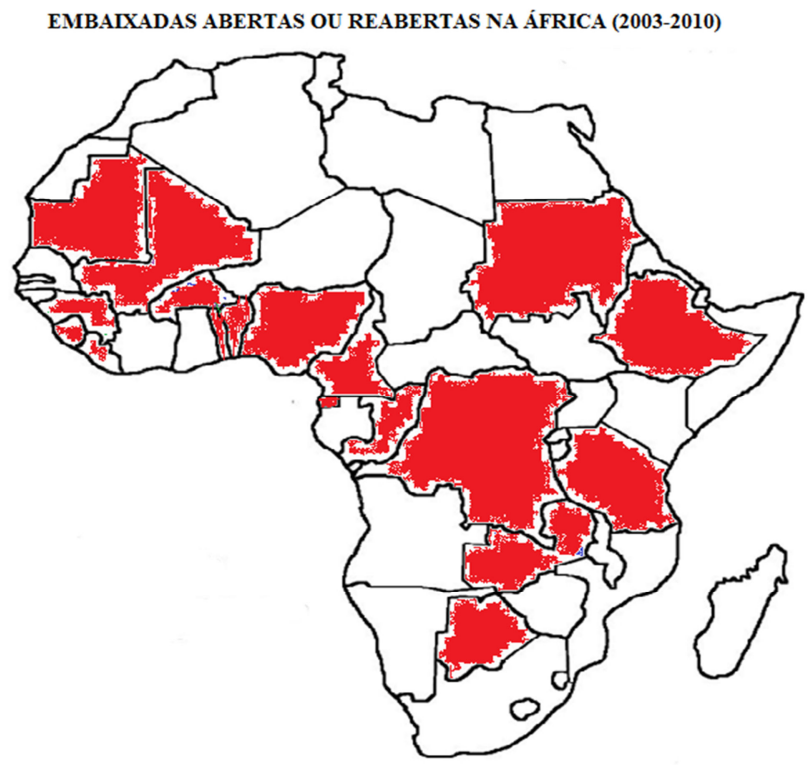

Fonte: MRE, 2010, p. 2.

Tabela 1 - Embaixadas por governo

\begin{tabular}{|c|c|c|c|c|}
\hline \multicolumn{2}{|c|}{$\begin{array}{c}\text { Embaixadas brasileiras na África } \\
(1995-2002)\end{array}$} & \multicolumn{3}{|c|}{$\begin{array}{c}\text { Embaixadas brasileiras na África (2003- } \\
\text { 2010) }\end{array}$} \\
\hline $\begin{array}{l}\text { África do Sul } \\
\text { Argélia } \\
\text { Angola } \\
\text { Cabo Verde } \\
\text { Camarões (fechada) } \\
\text { Costa do Marfim } \\
\text { Egito } \\
\text { Gabão } \\
\text { Gana } \\
\text { Guiné-Bissau } \\
\text { Líbia }\end{array}$ & $\begin{array}{l}\text { Marrocos } \\
\text { Moçambique } \\
\text { Namíbia } \\
\text { Nigéria (Lagos) } \\
\text { Quênia } \\
\text { República Democrática } \\
\text { do Congo (fechada) } \\
\text { Senegal } \\
\text { Tanzânia (fechada) } \\
\text { Tunísia } \\
\text { Zimbábue }\end{array}$ & $\begin{array}{l}\text { África do Sul } \\
\text { Argélia } \\
\text { Angola } \\
\text { Benin (2006) } \\
\text { Botsuana } \\
(2007) \\
\text { Burkina Faso } \\
\text { (2008) } \\
\text { Camarões } \\
\text { (reaberta em } \\
\text { 2005) } \\
\text { Costa } \\
\text { Marfim do } \\
\text { Congo (2008) } \\
\text { Egito } \\
\text { Etiópia (2005) } \\
\text { Gabão } \\
\text { Guiné }\end{array}$ & $\begin{array}{l}\text { Guiné-Bissau } \\
\text { Guiné } \\
\text { Equatorial } \\
\text { (2006) } \\
\text { Libéria (2010) } \\
\text { Líbia } \\
\text { Mali (2008) } \\
\text { Marrocos } \\
\text { Mauritânia } \\
\text { (2010) } \\
\text { Moçambique } \\
\text { Namíbia } \\
\text { Nigéria } \\
\text { (transferência } \\
\text { para Abuja - } \\
\text { 2004) } \\
\text { Quênia }\end{array}$ & $\begin{array}{l}\text { República } \\
\text { Democrática } \\
\text { do Congo } \\
\text { (reaberta em } \\
\text { 2004) } \\
\text { São Tomé e } \\
\text { Príncipe } \\
\text { (2003) } \\
\text { Senegal } \\
\text { Serra Leoa } \\
\text { (2010) } \\
\text { Sudão (2006) } \\
\text { Tanzânia } \\
\text { (reaberta em } \\
\text { 2005) } \\
\text { Togo (2006) } \\
\text { Tunísia } \\
\text { Zâmbia (2007) } \\
\text { Zimbábue }\end{array}$ \\
\hline \multicolumn{2}{|l|}{ TOTAL: 16} & \multicolumn{3}{|c|}{ TOTAL: 35} \\
\hline
\end{tabular}

Fonte: MRE

\footnotetext{
${ }^{16}$ Além disso, houve um crescimento na abertura de embaixadas africanas no Brasil, que passaram de 16
} para 29, com destaque para a inauguração de representações do Sudão e do Zimbábue (MRE, 2010, p. 2). 
Em relação a essas embaixadas, percebe-se que a partir do governo Lula todos os países de língua portuguesa e principais parceiros brasileiros no continente passam a contar com embaixadas brasileiras. Outro fato interessante é a transferência da representação brasileira em nosso principal parceiro nas importações vindas da África, a Nigéria, da cidade de Lagos, a maior cidade do país, o que mostrava a preferência por um relacionamento de caráter mais voltado para o plano comercial, para a capital do país, Abuja, o que poderia demonstrar o desejo do governo em estreitar seus laços com o governo nigeriano e ampliar a agenda bilateral.

Outros países que justificariam a abertura de embaixadas seriam o Benin e a Costa do Marfim, cuja participação no comércio com o continente é relevante, bem como em países como Camarões que possuem um papel importante no contexto regional. Em países como Mauritânia e Tanzânia, a abertura justifica-se por interesses comerciais, já que após a abertura dessas embaixadas houve o estabelecimento de empresas brasileiras nos mesmos.

Entretanto, ocorreu a abertura de embaixadas em países com os quais o Brasil possuía poucos contatos e teriam pouca relevância no cenário internacional e africano como Botsuana e Burkina Faso que também teriam pouca representatividade e atratividade do ponto de vista comercial, podendo, portanto, caracterizar uma estratégia de aproximação pouco pragmática e muito mais voltada ao discurso do que atitudes eu poderiam trazer benefícios ao Brasil e a esses parceiros.

No âmbito da estrutura administrativa do MRE, ocorreu o desmembramento do Departamento da África e do Oriente Médio, com a formação de um departamento dedicado apenas ao continente africano (DEAF). Ademais, dentro desse departamento, foi criada mais uma Divisão da África (DAF-III) ${ }^{17}$, além das duas já existentes ${ }^{18}$.

\footnotetext{
${ }^{17}$ A Divisão da África III é responsável pelas relações políticas bilaterais com: Argélia, Burundi, Djibuti, Egito, Eritreia, Etiópia, Líbia, Quênia, República Centro Africana, República Democrática do Congo, Ruanda, Somália, Sudão, Tanzânia, Tunísia, Uganda e assuntos relativos a IGAD, UMA, UA e NEPAD. (Fonte: http://www2.mre.gov.br/deaf/daf 3.htm)

${ }^{18}$ A Divisão da África I é responsável pelas relações políticas bilaterais com: Benin, Burkina Faso, Camarões, Chade, República do Congo, Costa do Marfim, Gabão, Gâmbia, Gana, Guiné (Conacri), Guiné Equatorial, Libéria, Mali, Marrocos, Mauritânia, Níger, Nigéria, Senegal, Serra Leoa, Togo e assuntos referentes a CEDEAO/ECOWAS, CEMAC, UEMOA, UMA, ZOPACAS e NEPAD (Fonte: http://www2.mre.gov.br/deaf/daf 1.htm). A Divisão da África II é responsável pelas políticas bilaterais com: África do Sul, Angola, Botsuana, Cabo Verde, Comores, Guiné-Bissau, Lesoto, Madagascar, Malaú, Maurício, Moçambique, Namíbia, São Tomé e Príncipe, Seicheles, Suazilândia, Zâmbia e Zimbábue e assuntos referentes a CPLP, SADC, UA, ZOPACAS e NEPAD (Fonte: http://www2.mre.gov.br/deaf/daf_2.htm).
} 
Além das visitas e das mudanças na estrutura do Itamaraty, o governo Lula teve outros gestos importantes com vistas a demonstrar que os interesses brasileiros seriam diferentes dos outros países que buscavam a aproximação com o continente africano. Para isso, o governo brasileiro perdoou a dívida de alguns países africanos, em atendimento às Metas do Milênio, como no caso de Moçambique, no qual o perdão chegou a 95\% da dívida (VIZENTINI, 2010).

Esses dados indicariam a tentativa do governo Lula de aprofundar e diversificar o seu relacionamento com o continente africano, conforme apontado pela literatura e pelos pronunciamentos oficiais.

\subsection{O fluxo comercial entre o Brasil e o continente africano entre 1995 e 2010:}

O intercâmbio comercial também apresenta diversificação de mercados e aumento das exportações brasileiras para a região, entretanto, a participação do continente africano no total das exportações brasileiras varia muito pouco, apesar do crescimento no volume das exportações totais do Brasil.

A participação africana nas exportações totais foi, em média, de 3,1\% em FHC, enquanto em Lula foi de 4,9\%, ou seja, um aumento de $1,8 \%$ pontos percentuais (Fonte: MDIC). Esse dado confirmaria que o continente africano cresce em termos de relevância comercial para o Brasil, ou seja, de que a estratégia de diversificação de mercados teria ocorrido. Entretanto, cabe ressaltar que a participação africana no total das exportações brasileiras ainda é tímida, ocupando em ambos governos a quinta posição.

Figura 11 - Participação da África nas exportações brasileiras por governo

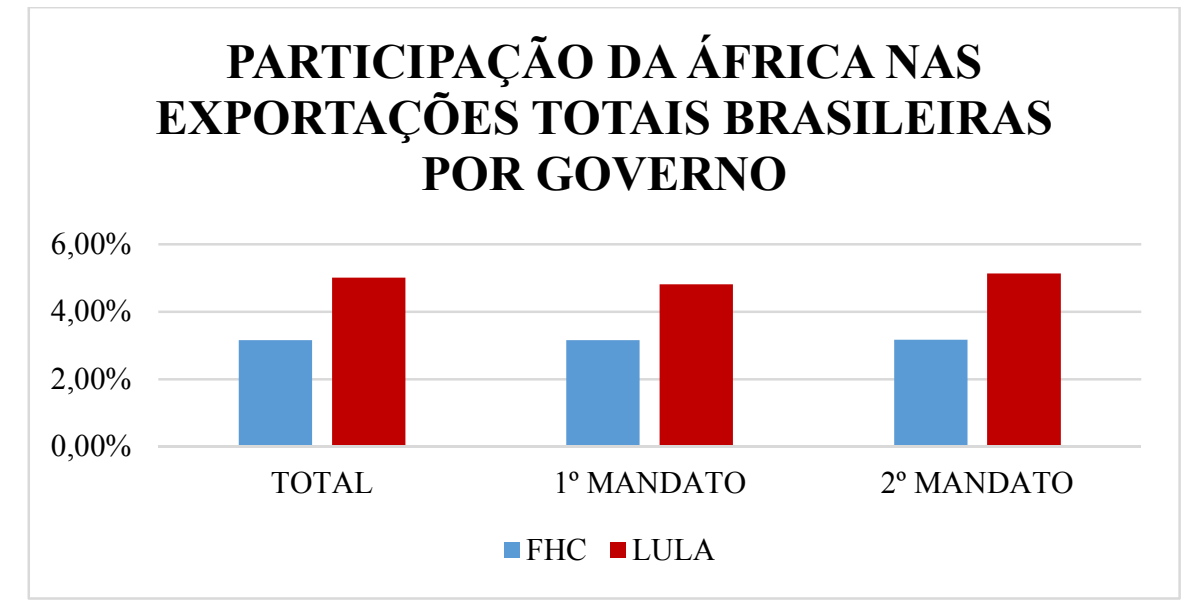

Elaboração própria. Fonte: MDIC. 
Entre 1995 e 2002, as exportações para aquele continente cresceram cerca de US\$ 500 milhões (ano-base 2005), uma variação de 26\% contra quase 159\% entre 2003 e 2010, passando de US\$ 3,03 bilhões em 2003 para US\$ 7,66 bilhões em 2010 (anobase 2005) (FONTE: MDIC). No caso do volume de exportações para o a África, a diferença entre os dois governos é muito maior do que no caso da participação, o que demonstraria que o crescimento das exportações para a região africana faria parte de um movimento de incremento geral das exportações brasileiras e não um fenômeno que denotaria relativa ênfase ao continente nas relações comerciais brasileiras.

Figura 12 - Exportações para a África por governo

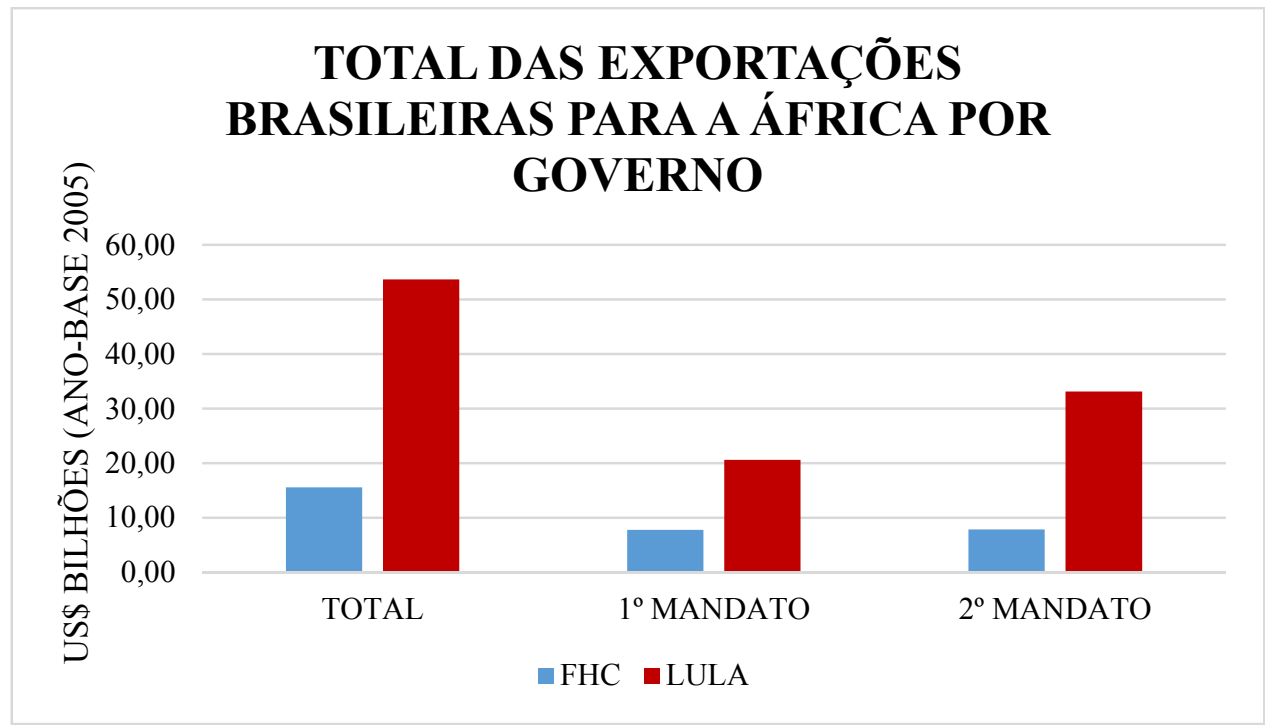

Elaboração Própria. Fonte: MDIC.

Ao verificar as exportações por região, percebe-se, nos dois governos, um equilíbrio em relação às mesmas, exceto pela África Oriental e África Central, cujas exportações não ultrapassam $5 \%$ das exportações totais para o continente africano. Deve-se atentar também ao fato de que no governo FHC que, segundo a literatura acerca de sua política africana, teria privilegiado os países de língua portuguesa, ao examinar as exportações, percebe-se que esses países possuem uma participação mínima no total das exportações brasileiras para o continente, cerca de 6,6\% (Fonte: AliceWeb).

Portanto, a apregoada seletividade no governo FHC não é comprovada ao atentar-se para a distribuição das exportações brasileiras por região da África. Ademais, no governo Lula, as exportações aumentam, principalmente, para os países de língua 
portuguesa, ocorrendo um incremento de 111\% (Fonte: AliceWeb) ${ }^{19}$ em relação ao governo anterior, enquanto a participação das outras regiões não apresenta uma mudança significativa. Sendo assim, também acontece uma seletividade no governo Lula, o que poderia ser explicado, em parte, pela proximidade linguística e cultural, fatores facilitadores para a realização de negócios.

Figura 13 - Participação das regiões africanas nas exportações para a África

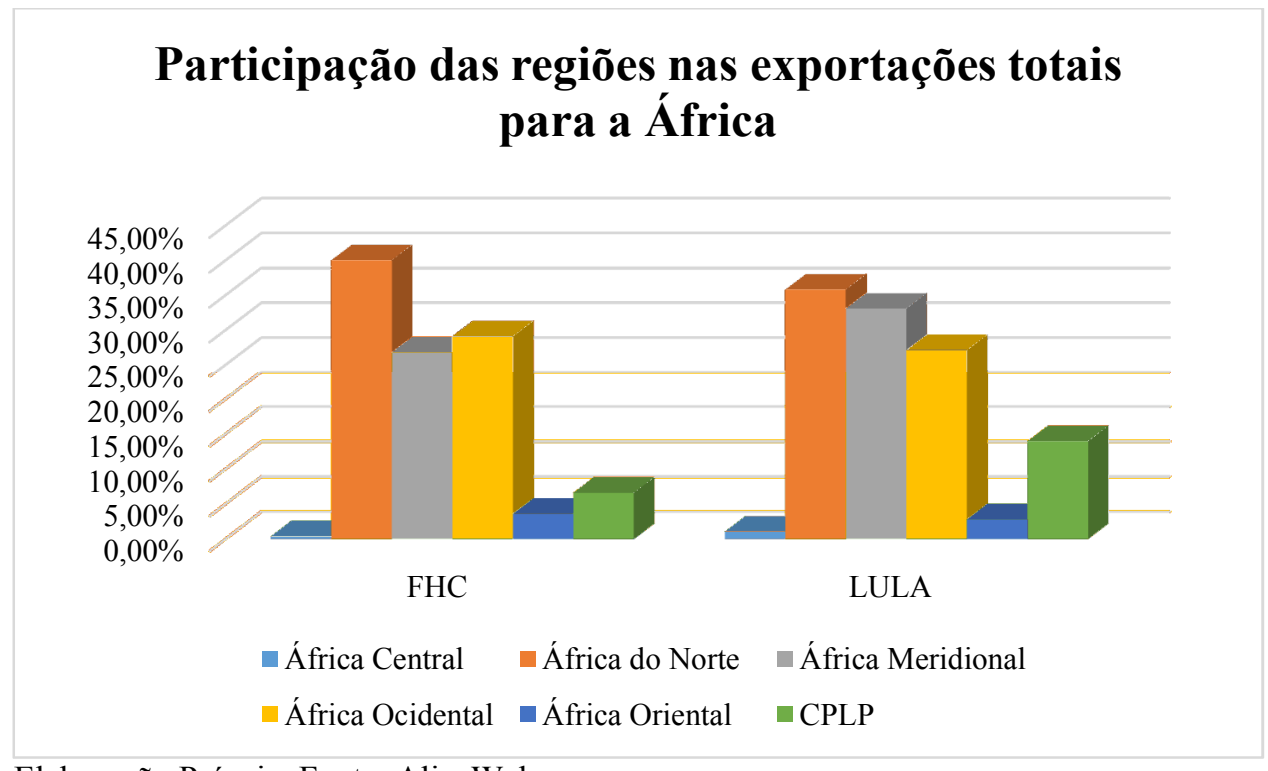

Elaboração Própria. Fonte: AliceWeb.

Em relação aos países compradores dos produtos brasileiros na África, não houve uma grande diversificação dos mercados compradores, já que a participação dos mesmos pouco foi alterada de um governo para outro. O que ocorre é uma mudança de posição em relação a esses mercados, com destaque para Angola e Argélia, cujas exportações aumentam, respectivamente, $124 \%$ e $78 \%$ entre os dois governos, enquanto as exportações para o Marrocos caem cerca de $41 \%$ no mesmo período. Uma das explicações para o aumento da participação angolana seria a recuperação da economia do país bem como a concessão de uma linha de crédito ao governo angola por parte do BNDES durante o governo Lula, o que facilitou a conclusão de diversos negócios com aquele país.

\footnotetext{
19 No governo Lula, as exportações para os países de língua portuguesa na África passaram a corresponder a $14 \%$ das exportações totais para o continente (Fonte: AliceWeb).
} 
Figura 14 - Mercados compradores na África

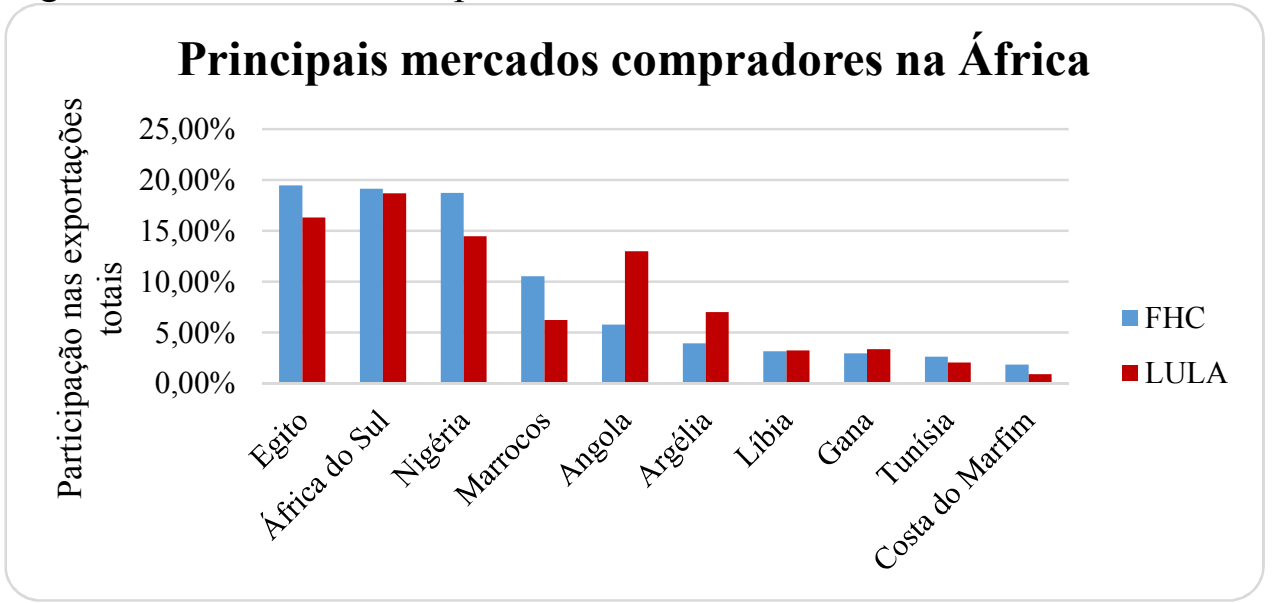

Elaboração Própria. Fonte: AliceWeb

Também não houve grandes modificações quanto aos produtos exportados para o continente, não mudando a posição dos dez principais produtos exportados para o continente, o que denotaria baixa diversificação de produtos exportados, diferente das intenções e tentativas do governo Lula e do que seria apontado por aqueles que defendem a política externa africana implantada por esse governo.

Figura 15 - Produtos exportados para a África

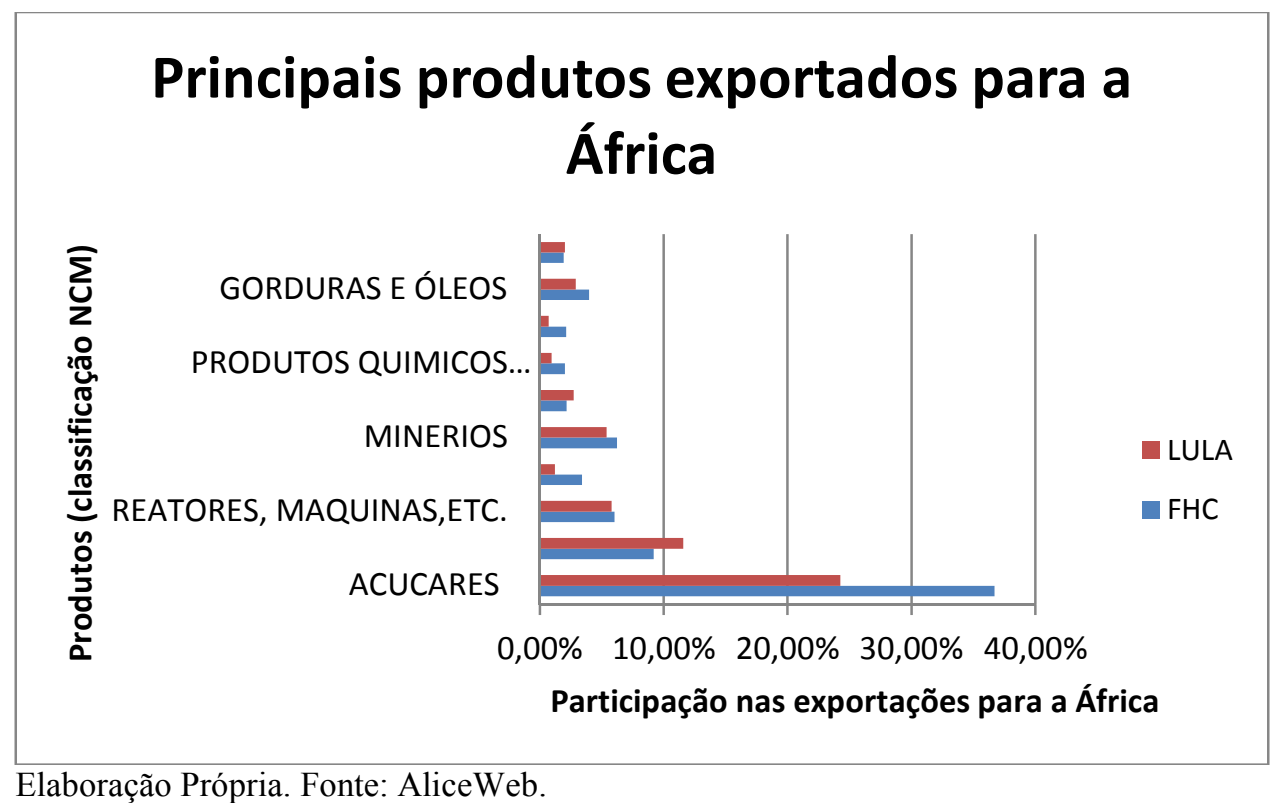

Também ocorreu um incremento da participação africana nas importações brasileiras, que passaram de 4,16\% no governo FHC para 8,09\% no governo Lula, ou seja, um crescimento de 95\% entre os dois governos (FONTE: MDIC). Entretanto, esse crescimento deveu-se ao aumento das importações totais, não alterando a posição dos 
países africanos no tocante às importações, continuando a ser o sexto mercado das compras brasileiras no exterior.

Figura 16 - Participação Africana nas Importações Brasileiras por governo

\section{PARTICIPAÇÃO AFRICANA NAS IMPORTAÇÕES BRASILEIRAS POR GOVERNO}

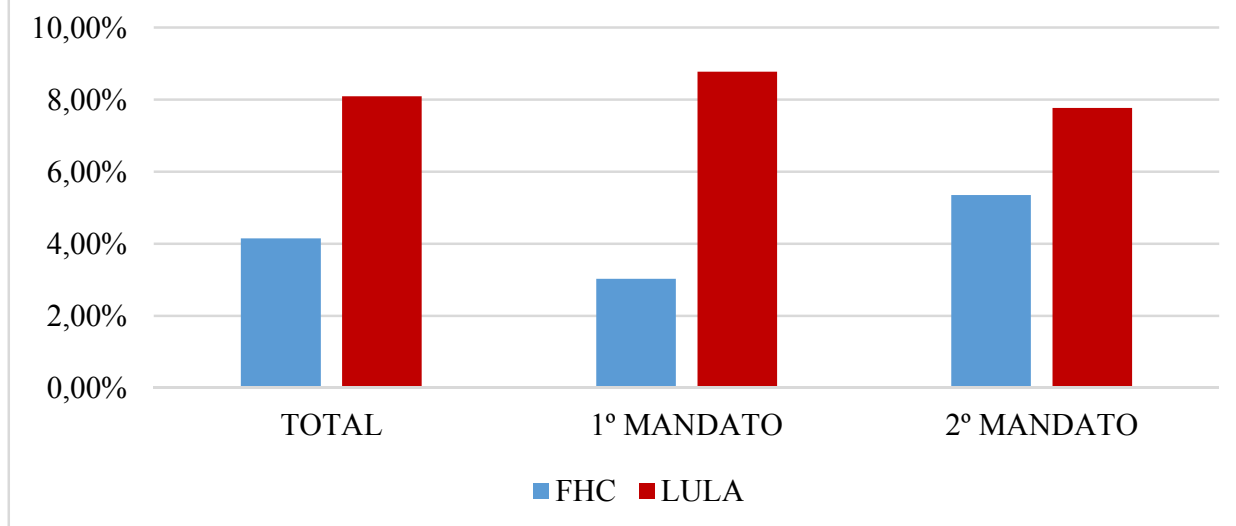

Fonte: AliceWeb. Elaboração Própria.

Entre os anos de 1995 e 2002, as importações originárias da África aumentaram $127 \%$, enquanto esse crescimento foi de $243 \%$ durante o governo seguinte (Fonte: MDIC). O volume de importações originárias da África cresceu de US\$17,8 bilhões (ano-base 2005) no governo FHC para US\$ 71,1 bilhões (ano-base 2005) no governo Lula, ou seja, um incremento de $299 \%$ entre os dois governos analisados, um crescimento muito superior ao crescimento o volume das importações totais entre os dois períodos que teria sido por volta de $105 \%$. Esse incremento teria ocorrido devido à compra de petróleo, ou seja, o Brasil reduziu as suas importações do Oriente Médio e passou a importa-lo da África, por meio da atuação da estatal brasileira Petrobrás. 
Figura 17 - Volume das Importações originárias da África por governo

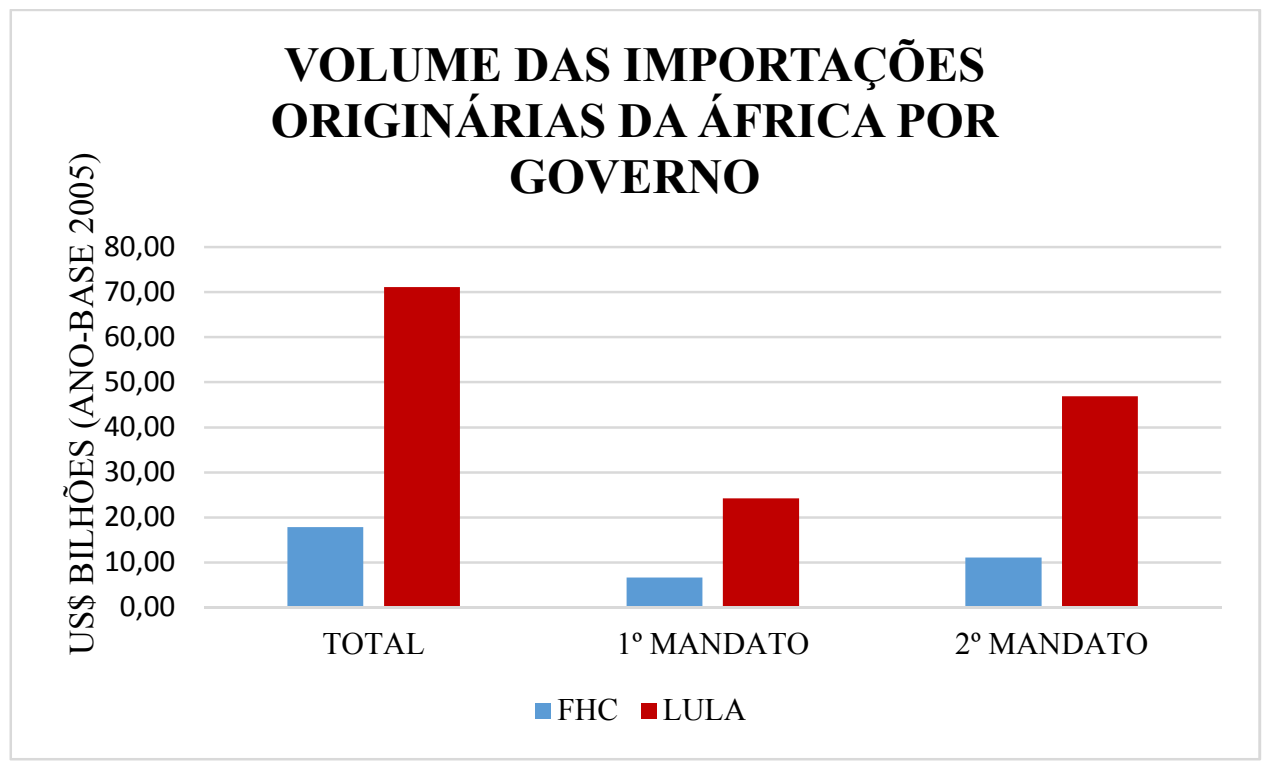

Elaboração Própria. Fonte: AliceWeb.

Assim como no caso das exportações, não houve grande alterações em relação às regiões africanas nas quais originam-se as importações brasileiras, com pouco destaque para as regiões da África Central e da África Oriental, que não chegam a representar $1,5 \%$ juntos. Isso ocorre devido ao fato de que não existirem, nessas regiões, grandes exportadores de petróleo, principal produto importado pelo Brasil.

As regiões que mais cresceram em participação foram a África Ocidental e a CPLP, cujos aumentos foram, respectivamente, de 36\% e 124\%, mais uma vez devido às importações de petróleo oriundas da Nigéria, pertencente à primeira região, e Angola, pertencente ao segundo grupo de país. Também ocorreram quedas nas importações originadas da África do Norte e da África Meridional, com destaque, nessa última região, à diminuição da participação de um parceiro tradicional brasileiro, a África do Sul.

Esses dados, portanto, demonstram que não teria ocorrido também no caso das importações a apregoada diversificação, pelo contrário, o que houve foi uma concentração nos países de língua portuguesa que, segundo a literatura especializada, teria a centralidade na política exterior do governo FHC e na Nigéria, principal fornecedor de petróleo do Brasil. 
Figura 18 - Participação das regiões africanas nas importações originárias da África

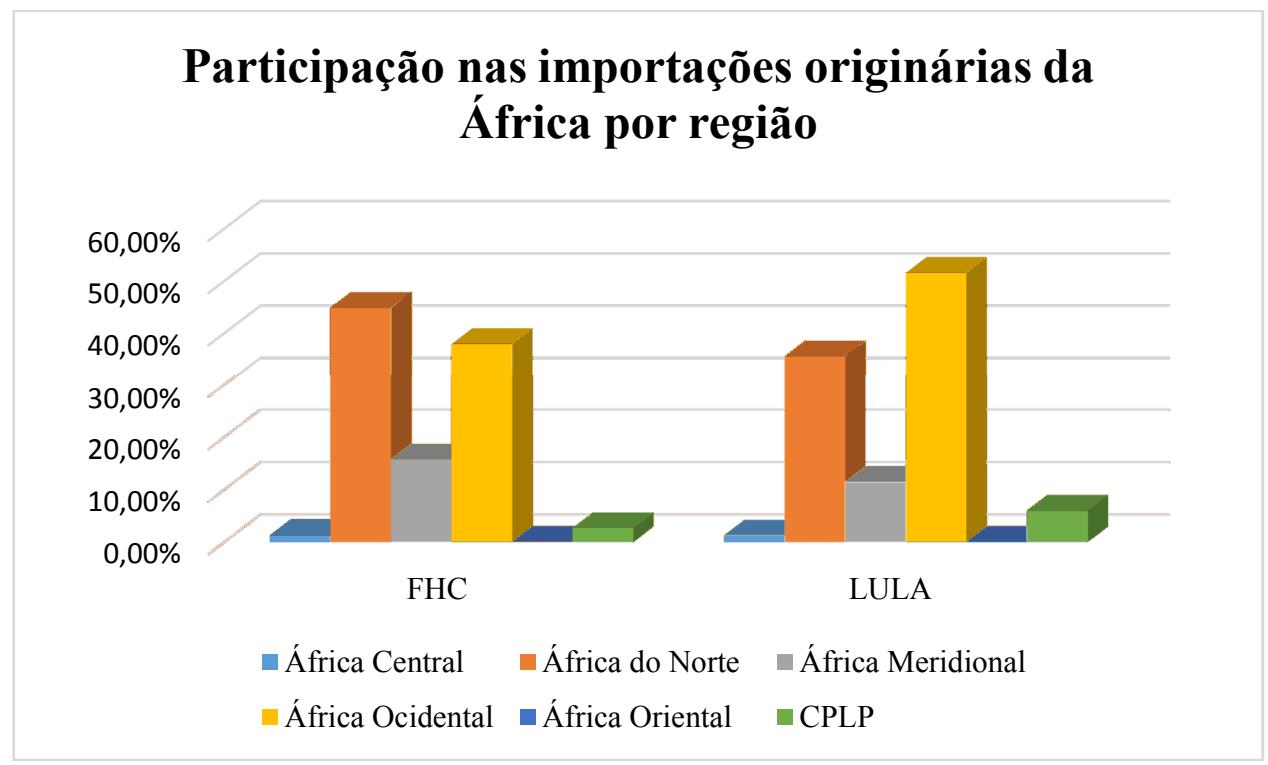

Elaboração Própria. Fonte: AliceWeb.

Essa afirmação pode também comprovada pela análise dos mercados fornecedores, já que, exceto no caso de Nigéria e Angola - importantes produtores de petróleo - e Marrocos - com um alta bastante discreta, todos os outros mercados tiveram a sua participação diminuída nas importações brasileiras.

Figura 19 - Mercados Fornecedores por governo

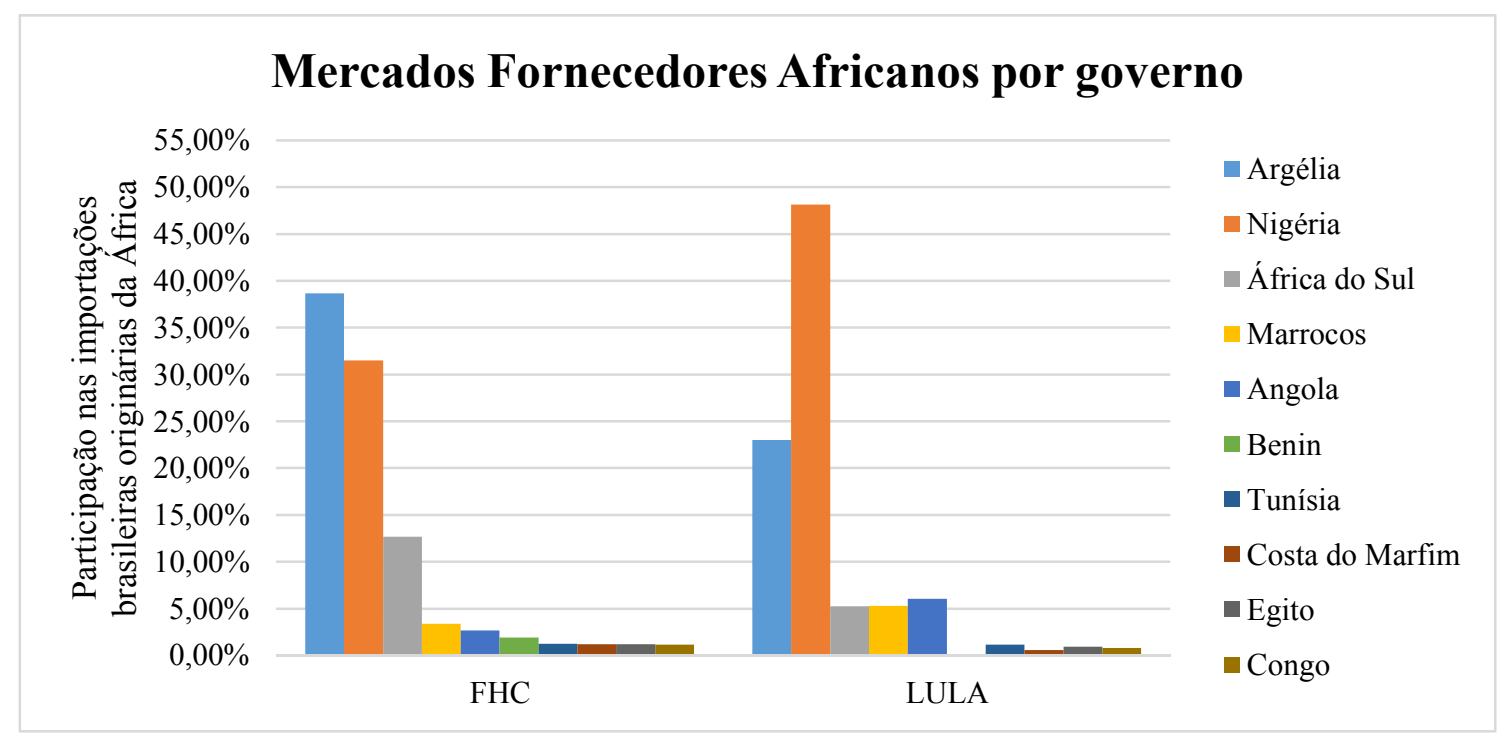

Elaboração Própria. Fonte: AliceWeb.

Conforme apontado acima, houve uma concentração também em relação aos produtos importados do continente africano, sendo que o petróleo e seus derivados seriam os principais produtos importados pelo Brasil, fato que não modificou-se entre 
os dois governos, mudando apenas a participação destes tipos de produtos nas importações originárias da África. As importações totais de petróleo passaram de US\$ US\$ 16,9 bilhões (ano-base 2005) no governo FHC para US\$ 61,9 bilhões (ano-base 2005), ou seja, um aumento de 60,9\% (FONTE: AliceWeb). Ademais, as importações brasileiras vindas da África continuaram concentradas no petróleo entre os dois governos, passando $78,2 \%$ no governo FHC para $87,05 \%$ no governo Lula.

Dessa maneira, a balança comercial Brasil-África, nos dois governos, é deficitária, devido à alta importação de petróleo africano para o mercado brasileiro. Assim como no caso das importações, o déficit é bem maior no governo Lula, em grande medida, pelo aumento nas importações de petróleo.

Entre os dois governos, o fluxo de comércio com a África cresceu 44\%, enquanto o fluxo de comércio do Brasil com o mundo no período cresceu 84,33\% (Fonte: MDIC), ou seja, o comércio do Brasil com o restante do mundo experimentou um incremento quase duas vezes maior, apontando, portanto que o intercâmbio com o mercado africano não acompanhou o intercâmbio brasileiro com o restante do mundo. Isso denotaria que, apesar do crescimento significativo das relações comerciais com a África, o continente ainda não tem uma participação tão relevante no comércio brasileiro.

Figura 20 - Fluxo Comercial com a África por governo

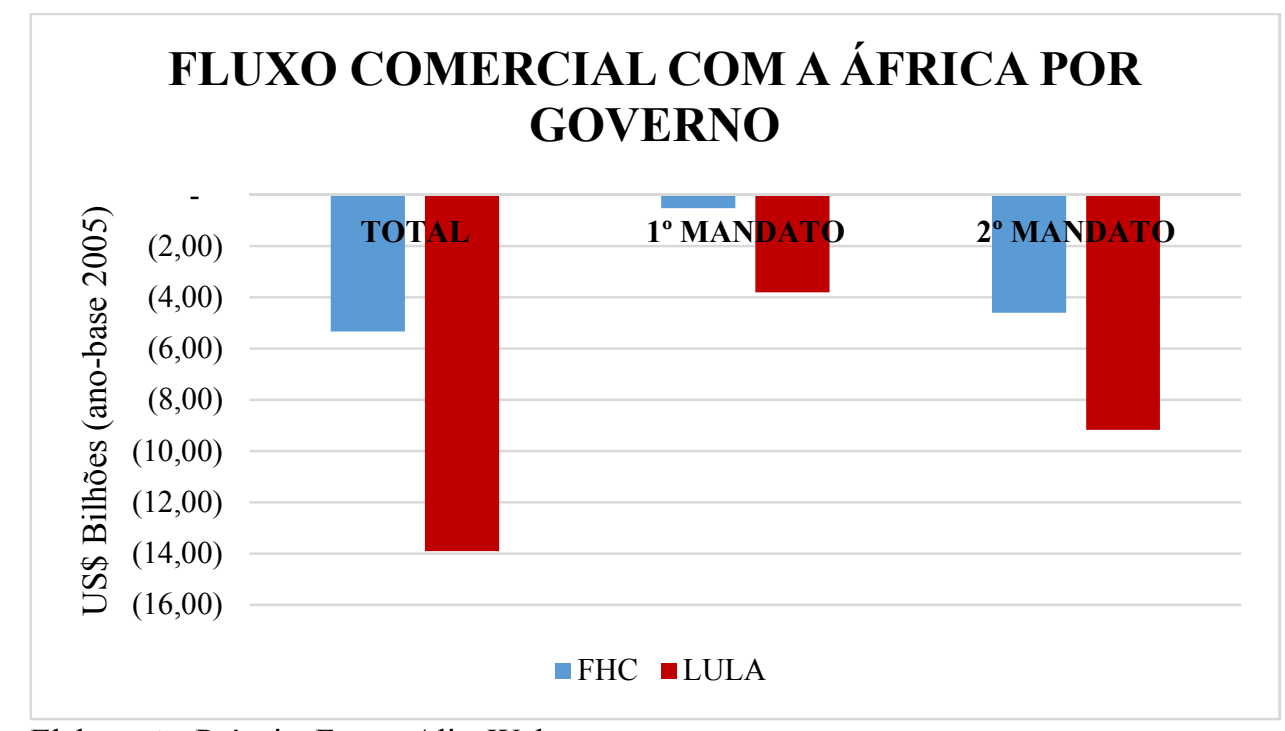

Elaboração Própria. Fonte: AliceWeb.

Apesar disso, houve uma elevação da participação de empresas brasileiras no mercado africano, cuja atuação está ligada, principalmente, à exploração das 
oportunidades nacionais ou regionais, extração de recursos naturais e construção de grandes obras públicas, como estradas, usinas de energia.

Um dos fatores que podem ter levado a essa elevação é a atuação do Banco Nacional de Desenvolvimento Econômico e Social (BNDES), cujos incentivos e desembolsos aumentaram de forma representativa no governo Lula ${ }^{20}$. A partir do lançamento do Programa de Integração com a África, em 2008, os desembolsos do BNDES passaram de R \$ 477 milhões em 2008 para R \$ 649 milhões no ano seguinte (IPEA, 2011).

Além disso, houve a assinatura de um acordo entre o BNDES e a Agência Brasileira para a Promoção de Exportações (APEX) para diversificar as exportações brasileiras para o continente africano, cuja concessão de aproximadamente US\$ 500 milhões, em 2008, beneficiou algumas empresas nacionais.

Por meio da atuação do BNDES, houve a criação de linhas de crédito para países africanos para projetos específicos. Merecem destaque, nesse sentido, a linha de crédito relativa ao desenvolvimento de indústrias de processamento de etanol de cana de açúcar para Angola, em 2006, no valor de US\$ 1,5 bilhão e para empresas atuantes em Gana e Moçambique, com um orçamento de US\$ 3,5 bilhões (IPEA, 2011).

Os dois países africanos que mais receberam desembolsos foram Angola e Guiné Equatorial, no valor de US\$ 498 milhões e US\$ 7,9 milhões, respectivamente, correspondendo a $44 \%$ dos desembolsos totais do banco por país (FONTE: BNDES). Essa estratégia é importante, pois a exportação de produtos de alto valor agregado - que é o objetivo brasileiro - depende, em grande medida, de financiamento, algo raro entre os países africanos que não possuem um sistema financeiro robusto o suficiente para realizar esse tipo de operação. Dessa maneira, apesar de parecerem limitados, esses recursos são considerados importantes pelos países africanos, cujo acesso às fontes tradicionais de financiamento é escasso, o que garantiria maior aproximação para o Brasil com esses países.

O setor privado brasileiro iniciou seus investimentos na África nos anos 80 . Atualmente, os principais setores de atuação de empresas brasileiras são infraestrutura, energia e mineração.

\footnotetext{
${ }^{20}$ Esse aumento teria ocorrido devido à mudança de estatuto, ainda no final do governo FHC, que permitiu ao BNDES apoiar projetos de empresas brasileiras no exterior, processos de fusões e aquisições internacionais e empréstimos para países que contratem empresas brasileiras.
} 
No setor de infraestrutura, destacam-se as grandes construtoras brasileiras, Odebrecht, Andrade Gutierrez e Camargo Correa, cujas presenças já são antigas no continente, Queiroz Galvão e OAS, cuja atuação iniciou-se no governo Lula, em grande medida devido à facilitação de obtenção de crédito via BNDES e ao aumento de obras de infraestrutura na região, a partir da melhora nos índices de crescimento e da resolução de conflitos internos no continente.

A Odebrecht é empresa brasileira com maior número de projetos na África, presente na África do Sul, Angola, Botsuana, Djibouti, Gabão, Líbia, Libéria, Moçambique e República Democrática do Congo. Além de atuar sozinha, a empresa também possui parcerias com governos e outras empresas estrangeiras, além de ter criado consórcios com outros empreiteiros brasileiros na África. Entre as atividades desenvolvidas, encontram-se projetos relacionados à exploração de petróleo e gás, à infraestrutura, à construção de condomínios residenciais, ao planejamento urbano, à operação de minas de diamantes e à distribuição de alimentos (IPEA, 2011, p. 88-9).

A Andrade Gutierrez atua, principalmente, no setor de construção civil em Angola, Argélia, Camarões, Guiné, Guiné Equatorial. Líbia, Mali, Mauritânia, Moçambique e República Democrática do Congo. A empresa foi responsável pela construção de diversas rodovias e estradas, além de ter realizado projetos de habitação, construção civil e planejamento urbano (IPEA, 2011, p. 89).

A Camargo Correa atua, na África, em projetos de planejamento urbano e construção de moradias, estradas e linhas de transmissão de energia em Angola, Líbia e Moçambique (IPEA, 2011, p. 89).

Por sua vez, a Queiroz Galvão possui obras de construção civil em Angola e na Líbia.

Uma das principais vantagens dessas empresas brasileiras em relação ao seu principal concorrente na África, a China, é a contratação de mão de obra local para seus projetos e o desenvolvimento de capacidades locais, o que pode ser comprovado pelo fato de que a Odebrecht tornou-se o principal empregador privado em Angola (IPEA, 2011, p. 87). Essa estratégia fortaleceria os laços com a sociedade desses países, o que, por sua vez, poderia facilitar o relacionamento com os governos desses países.

O setor de mineração é dominado Vale, com projetos em países como África do Sul, Angola, Gabão, Guiné-Bissau, República Democrática do Congo e Zâmbia. Seu 
principal projeto é em Moçambique, onde venceu concorrência internacional para a exploração de carvão, em Moatize ${ }^{21}$ (IPEA, 2011, p. 89).

$\mathrm{Na}$ área de energia ocorre o predomínio da estatal Petrobrás, com operações para busca e exploração de petróleo especialmente em águas profundas e ultraprofundas, com atividades em Angola, Líbia, Namíbia, e Tanzânia, além da Nigéria, principal fornecedor do petróleo importado pelo Brasil ${ }^{22}$ (MRE, 2010, p. 2).

Exceto por essas empresas tradicionais, o número de empresas brasileiras dispostas a explorar o mercado africano ainda é pequeno, destacando-se a produção de ônibus pela Marcopolo, no Egito e na África do Sul, e a RANDOM, na Argélia e no Quênia. Angola ainda é o parceiro comercial mais tradicional do Brasil, com empresas como O Boticário e Nobel ${ }^{23}$, dentre outras.

Esses dados relativos à presença de empresas brasileiras no continente africano ainda apontam uma forte concentração de projetos em parceiros tradicionais, principalmente, nos países de língua portuguesa, algo que deve-se, não apenas a questões econômico-comerciais, mas também a questões culturais como a proximidade linguística, o que facilitaria os negócios.

Dessa maneira, percebe-se que um exame mais aprofundado das relações comerciais entre Brasil e África demonstra que não houve alterações muito significativas no perfil desse relacionamento que, conforme foi demonstrado, ainda possui uma participação baixa no total do fluxo de comércio brasileiro assim como cresceu, entre os dois governos, bastante abaixo do crescimento do fluxo comercial total do Brasil.

\subsection{A cooperação técnica entre o Brasil e a África:}

Além do intercâmbio comercial, outro elemento de destaque no aprofundamento das relações Brasil-África entre os governos FHC e Lula foi a cooperação técnica ${ }^{24}$, nas

\footnotetext{
${ }^{21}$ Essa operação demandará mais de US\$ 4,5 bilhões de investimentos, boa parte dele em infraestrutura, a ser desenvolvida pelas empreiteiras brasileiras Odebrecht e Andrade Gutierrez.

${ }^{22}$ A partir da entrada em operação dos poços de Agbami e Akpo, a Nigéria será uma das maiores produtoras da empresa fora do país.

${ }^{23}$ Vale destacar que, para aumentar a presença brasileira na região, em muitas de suas viagens o presidente Lula era acompanhado por empresários brasileiros. Ademais, outros ministérios foram envolvidos nessa empreitada, com missões organizadas pelo Ministério do Desenvolvimento, Indústria e Comércio (MDIC).

${ }^{24}$ Nessa tese, entende-se o conceito de cooperação técnica como sendo a "cooperação centrada no intercâmbio de conhecimentos técnicos e de gestão, com o fim de aumentar as capacidades de instituições e pessoas para promover seu próprio desenvolvimento" (ARMIÑO, 2001). A cooperação técnica,
} 
mais variadas áreas como agricultura, saúde, educação, meio ambiente e capacitação profissional $^{25}$.

A partir da Resolução 200 de 1948, da Assembleia Geral das Nações Unidas (AGNU), a cooperação técnica seria composta por três elementos: a transferência não comercial de técnicas e conhecimentos; desnível quanto ao desenvolvimento alcançado entre receptor e prestador; execução de projetos conjuntos, envolvendo peritos, treinamento de pessoal, material bibliográfico, equipamentos, estudos e pesquisas (JÚNIOR, 2013, p. 109).

A partir da evolução do conceito e da aplicação da cooperação técnica, países em desenvolvimento como o Brasil, poderiam utilizar de maneira mais eficiente sua capacidade instalada e superar as relações de dependência inerentes aos mecanismos de cooperação Norte-Sul ao lançar-se à cooperação Sul-Sul.

No caso brasileiro, a partir de 1987, com a criação da Agência Brasileira de Cooperação $(\mathrm{ABC})^{26}$, responsável pela centralização da cooperação no âmbito da estrutura do Ministério das Relações Exteriores, houve a diferenciação entre a Cooperação Técnica para o Desenvolvimento (CTPD) e a cooperação técnica tradicional. Esse processo deu-se por meio do esvaziamento do discurso de assimetria entre doador e beneficiário, presentes na cooperação Norte-Sul, o que permitiria a diminuição da distância entre os participantes da CTPD e justificaria a ideia de parceria que deveria guiar a aliança Sul-Sul (VALLER FILHO, 2007).

O processo para a construção de projetos de cooperação com o Brasil ocorre da seguinte maneira: as demandas por cooperação apresentadas às embaixadas brasileiras

portanto, abrangeria "um elenco de atividades interligadas (tipicamente, identificação de especialistas, obtenção de meios financeiros, operacionalização do mecanismo de transferência dos conhecimento e técnicas pertinentes, avaliação da competência adquirida pela entidade receptora, avaliação ex-post dos resultados alcançados com o uso da nova competência, e outras) que envolvem a mobilização transitória de recursos humanos, materiais e financeiros. Essa mobilização, que gera uma pequena organização ad hoc, cessa ao final do prazo consignado para a consecução do objetivo especificado, isto é, quando a organização receptora (idealmente) passou do nível inferior para o superior de conhecimento a respeito do tema" (PLONSKI, 1994, p. 369).

${ }^{25}$ Entre os anos de 1998 a 2003, havia cerca de 119 projetos em andamento, enquanto de 2003 a 2007 , esse projetos totalizaram 125. Entretanto, o que chama atenção não é o aumento no número de projetos, mas sim na ampliação de seus beneficiários a países não-lusófonos, como Botsuana, Burkina Faso, Gâmbia, Guiné Equatorial, Sudão, entre outros (ABC)

26 A Agência Brasileira de Cooperação, criada no ano de 1987, seria uma agência especializada, subordinada ao MRE (por meio da Fundação Alexandre de Gusmão - FUNAG), sendo dotada de funções técnicas e executivas. Essas funções seriam: a coordenação da elaboração de programas de cooperação técnica em articulação com órgãos e entidades nacionais e internacionais; recebimento, seleção e encaminhamento às fontes externas os projetos correspondentes e o monitoramento e avaliação periódica das atividades relacionadas a cada um deles. 
no exterior seriam consolidadas por meio da $\mathrm{ABC}$, que as analisa e, em articulação com empresas e entidades nacionais, procuraria atendê-las tendo em mente as diretrizes gerais da política externa do país (JÚNIOR, 2013).

Nos anos recentes, a diretriz básica da CTPD brasileira permaneceu inalterada, continuando a pautar-se pela transferência de conhecimentos e tecnologias para os países em desenvolvimento, a capacitação de recursos humanos e a formação profissional.

Essa cooperação ganha força a partir do início dos anos 2000 que, além de manter a sua ligação com o discurso desenvolvimentista - tradicional na política externa do Brasil - também teria como função adicional contribuir para o processo de desenvolvimento interno - o principal objetivo a ser defendido pela política exterior brasileira.

Além das considerações de ordem técnica, existem as considerações de ordem política, ou seja, a cooperação poderia ser um instrumento para aprofundar as relações com outros Estados, mecanismo que vem sendo utilizado pelo Brasil para reforçar o seu relacionamento com a América Latina e com os países africanos de língua portuguesa, regiões importantes para a política externa brasileira (PUENTE, 2010).

Os projetos de CTPD no período estudado se concentraram exatamente nessas regiões consideradas prioritárias para a política externa brasileira - África e América do Sul. O que mudou foi a posição dessas duas regiões, enquanto no governo FHC a América do Sul ocupava o primeiro lugar, com cerca de 30\% dos projetos e a África o segundo lugar, com cerca de $26 \%$ dos projetos de cooperação. No governo seguinte, as posições se invertem, o continente africano ocupa a primeira posição com cerca de $36 \%$ dos projetos enquanto a região sul-americana vai para o segundo lugar, com uma participação de cerca de 27\% (PUENTE, 2008, p. 173).

Ao comparar a cooperação técnica com os países africanos também percebe-se um expressivo crescimento entre os dois governos, a diversificação nos países beneficiados e nas áreas em que ocorreram esses projetos. Enquanto no governo FHC, foram assinados projetos com 13 países africanos em 16 diferentes áreas, no governo Lula, o número de países beneficiados no continente africano foi de 38 em 30 diferentes áreas (FONTE: DAI-MRE). 
Figura 21 - Quadro Comparativo de Beneficiados e Áreas de CTPD por governo

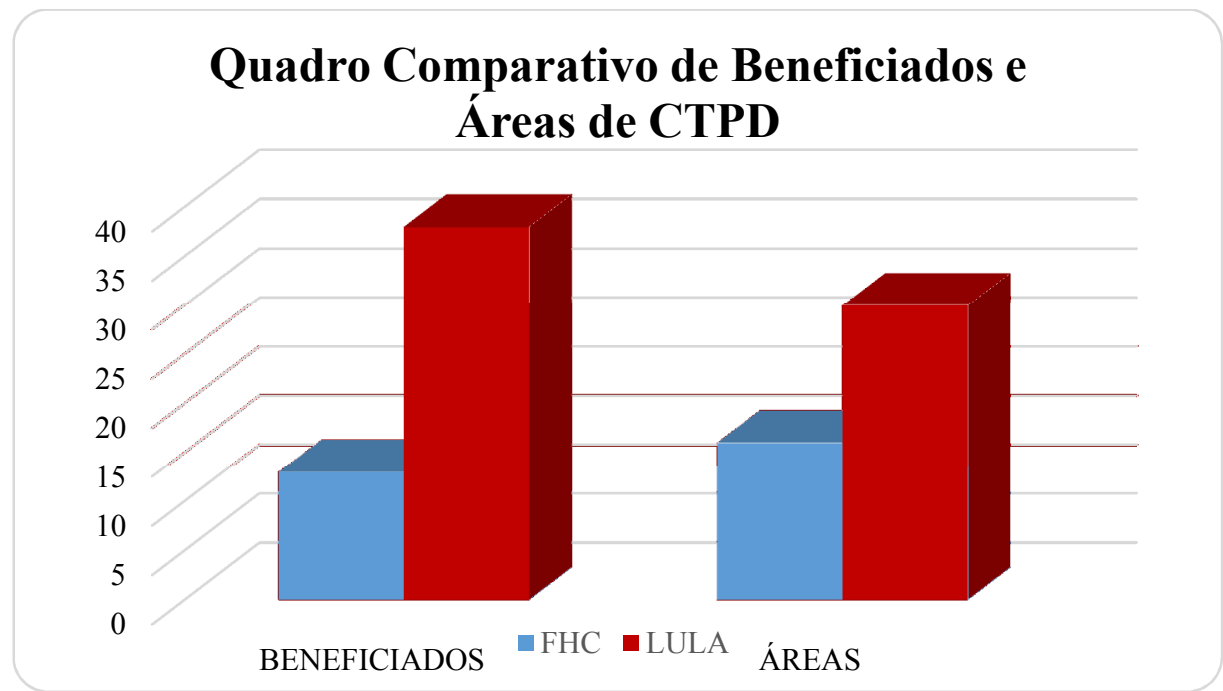

Elaboração Própria. Fonte: DAI-MRE.

Aparentemente, ocorre maior diversificação na participação das regiões nos projetos de cooperação, com o crescimento em quatro das cinco regiões africanas, com exceção à África Meridional, que experimenta uma queda de 27,7 pontos percentuais. No governo FHC, os projetos eram direcionados para a África Meridional, mais especificamente, África do Sul recém saída do apartheid, CPLP e África Ocidental, composta por três países de língua portuguesa. No governo seguinte, não ocorre uma alteração significativa em relação ao governo anterior nas regiões mais beneficiadas por projetos de cooperação, exceto pelo aumento da participação da África do Norte nos mesmos.

Figura 22 - Participação das regiões africanas na CTPD para a África 


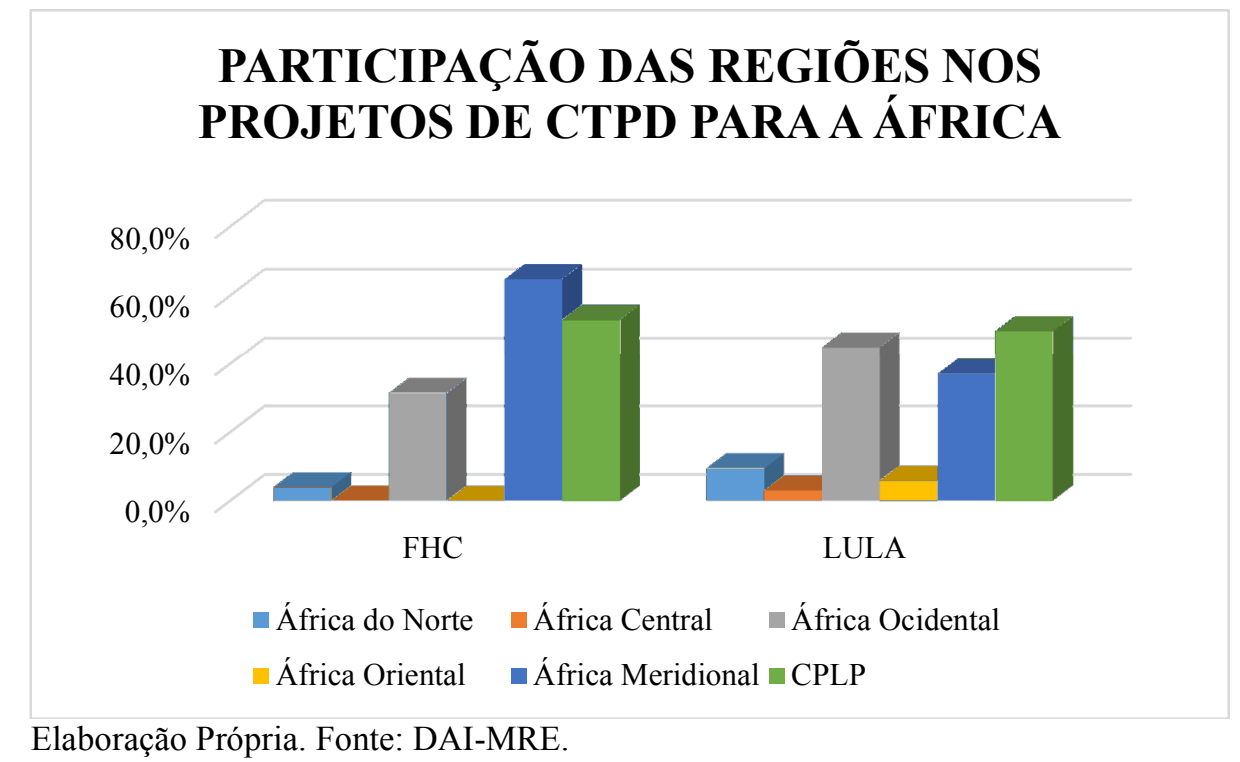

Elaboração Própria. Fonte: DAI-MRE.

Assim como ocorre no caso das relações comerciais, apesar da diversificação dos países beneficiados no governo Lula, existe uma centralização dos projetos nos países de língua portuguesa em ambos os governos. No governo FHC, esses países correspondem a $52,9 \%$ do total de projetos para o continente africano enquanto no governo seguinte esse número cai para $49,6 \%$ do total de projetos para África (FONTE: DAI-MRE).

Figura 23 - Participação por país na CTPD para a África- FHC

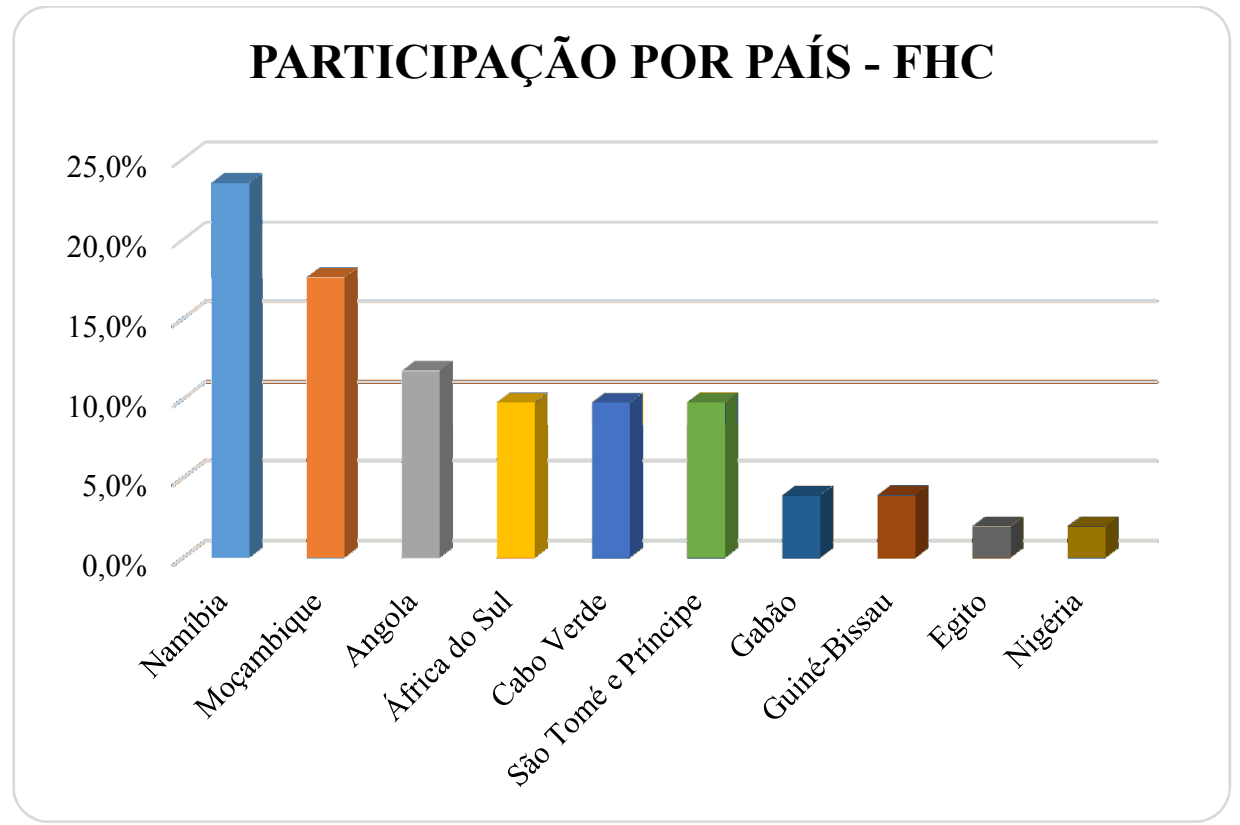

Elaboração Própria. Fonte: DAI-MRE.

Figura 24 - Participação por país na CTPD para a África - Lula 


\section{PARTICIPAÇÃO POR PAÍS - LULA}

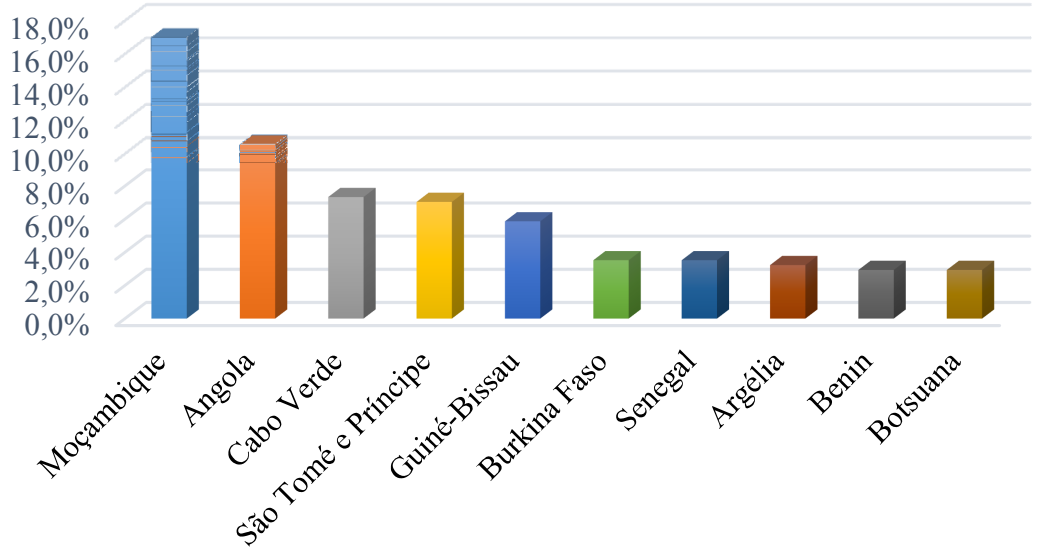

Elaboração Própria. Fonte: DAI-MRE.

As áreas predominantes nos projetos de cooperação nos dois governos são semelhantes, destacando-se a saúde, educação, cultura e agricultura. Vale mencionar que o governo Lula foi responsável pela assinatura de vários acordos gerais ${ }^{27}$ de cooperação - 16 acordos -, enquanto seu antecessor assinou apenas com 2 países, chamando a atenção o fato de que um dos países foi a Namíbia, Estado fora da zona considerada prioritária pelo governo $\mathrm{FHC}$ em sua política externa para o continente (FONTE: DAI-MRE).

Figura 25 - Projetos de cooperação com a África por área

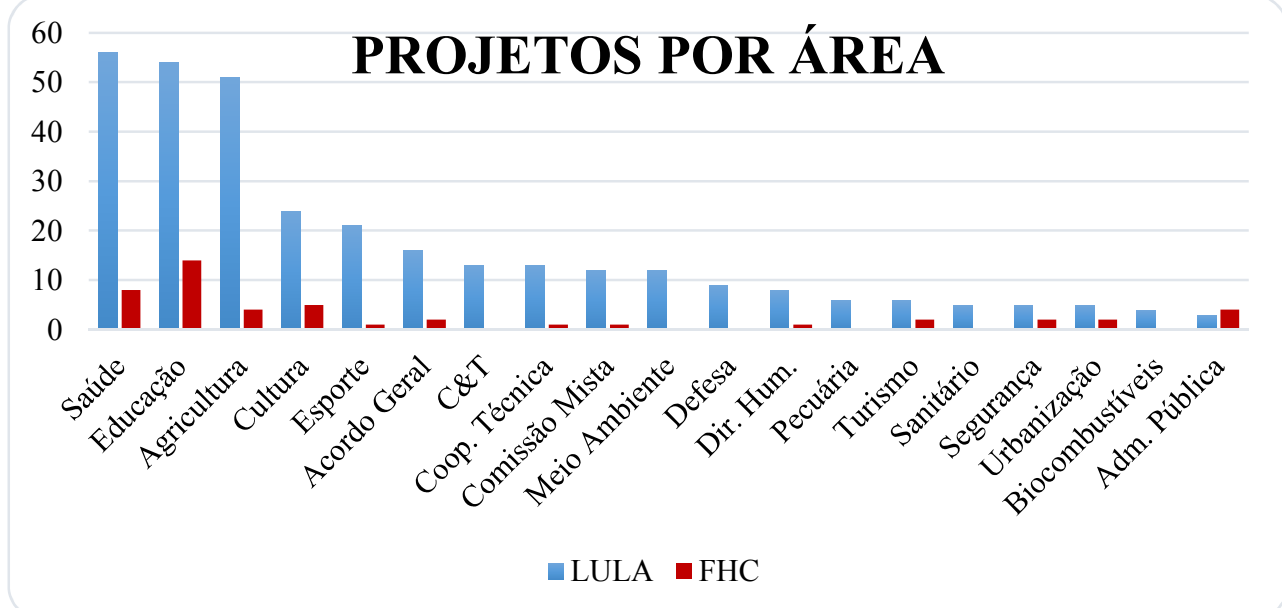

Fonte: DAI-MRE. Elaboração Própria.

\footnotetext{
${ }^{27}$ Os acordos gerais são relevantes, pois seriam o primeiro passo diplomático para a concertação de objetivos relacionados à cooperação.
} 
Portanto, percebe-se que seria no campo da cooperação em que ocorre uma maior diversificação no governo Lula, tanto nas regiões e nos países benficiados e em relação às área em que são assinados mecanismos de cooperação técnica.

\subsection{Considerações finais do capítulo:}

Fica claro que no governo FHC, o relacionamento comercial, diplomático e técnico com o continente teria ficado restrito aos parceiros tradicionais, principalmente, àqueles de língua portuguesa e à África do Sul nas duas variáveis analisadas, e aos países produtores de petróleo na variável comércio, mantendo, portanto, uma aproximação seletiva, baseada nas diretrizes do modelo de desenvolvimento e de política externa, voltadas, principalmente, à conquista da confiança dos países desenvolvidos e à ampliação da integração regional. Nesse sentido, a África não iria ao encontro desses objetivos, o que justificaria a pouca atenção dispensada ao continente.

Com a relativa alteração na estratégia de desenvolvimento e, consequentemente, da política exterior, mais identificada com a atuação característica de país intermediário e, portanto, de maior aproximação com os países em desenvolvimento houve um renascimento da política africana - tradicional na corporação diplomática e defendida por membros do PT - por meio da ampliação de parceiros africanos não apenas no âmbito comercial, mas em áreas diversas, como a cooperação técnica para o desenvolvimento. Portanto, a aproximação Brasil-África no governo Lula teria sido diversificada, já que teria ampliado as áreas de atuação naquela região a países com os quais esse relacionamento era inexistente ou havia sido abandonado.

A passagem da aproximação seletiva em FHC para a aproximação diversificada em Lula nas relações Brasil-África, a partir do aumento das viagens presidenciais, da ampliação das embaixadas brasileiras na região e da estrutura do Itamaraty para a região, do incremento do intercâmbio comercial - em termos geográficos e quantitativos - e de projetos de cooperação técnica, demonstram, o que Hermann (1990) chamaria de ajustes $^{28}$, pois aumentou-se a ênfase no relacionamento com os PEDs, e de mudanças de programa $^{29}$ seja a introdução de novos instrumentos à consecução do objetivo principal

\footnotetext{
${ }^{28}$ Ajustes seriam modificações ocorridas no nível do esforço - maior ou menor - e/ou no escopo dos receptores.

${ }_{29}$ Mudanças de programa seriam aquelas nos métodos ou meios por meio dos quais o objetivo ou problema seria solucionado, sendo qualitativas e envolvendo novos instrumentos.
} 
- no caso brasileiro, o desenvolvimento - como os empréstimos do BNDES à operação de empresas brasileiras na região e o incremento da cooperação técnica.

Essas modificações poderiam ser resumidas pelo mapa a seguir.

Figura 26 - A presença brasileira na África

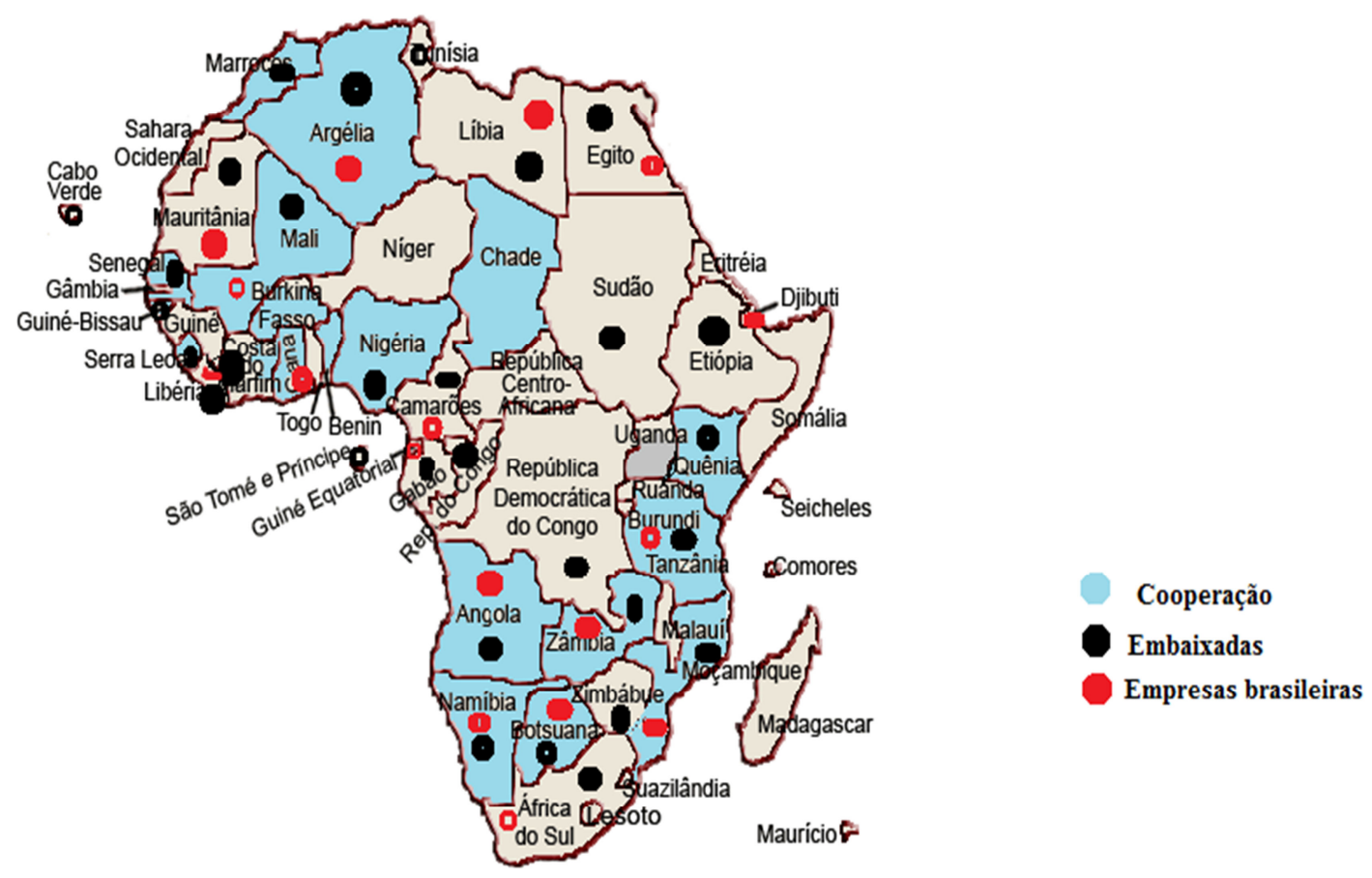

Em contrapartida ao fortalecimento do relacionamento bilateral com o continente africano, o Brasil conseguiu, no governo Lula, o apoio dos países da CPLP em diversas candidaturas brasileiras a cargos em organismos internacionais, como o Conselho de Segurança da ONU e a Diretoria-Geral da Organização das Nações Unidas para Alimentação e Agricultura (FAO). 
Essas modificações, conforme demonstrado, teriam sua origem nas percepções dos líderes que promoveram alterações na burocracia responsável pela formulação e implementação da política externa brasileira, percebendo-se um incremento na participação do Itamaraty e do presidente nestas questões entre os dois governos analisados. Entretanto, não houve no período, mudanças na estrutura doméstica e choques externos que pudessem alterar, substancialmente a política externa brasileira, já que esta continuou a estar voltada ao desenvolvimento - que, a partir dos anos 90, estaria fortemente ligado à estabilidade macroeconômica e ampliação dos mercados e exportações do Brasil - modificando apenas o seu papel, de auxiliar para ser um instrumento para a consecução do mesmo. Sendo assim, o continente africano, a partir dessas visões, ganha importância na política externa brasileira ao longo dos dois governos estudados.

\section{CAPÍtUlO III - A CONVERGÊNCIA ENTRE O BRASIL E ÁFRICA NA ASSEMBLEIA GERAL DAS NAÇÕES UNIDAS (AGNU)}

\subsection{A utilização das votações na AGNU como parâmetro para medição das orientações gerais das políticas externas dos Estados}

A tarefa de medir, de maneira quantitativa, as orientações gerais bem como os alinhamentos no sistema internacional é uma tarefa bastante difícil, pois existem poucas ferramentas que podem ajudar nesse objetivo. Uma das possibilidades mais utilizadas pelos pesquisadores de Relações Internacionais é as votações ocorridas no âmbito da Assembleia Geral das Nações Unidas, já que esse seria o principal fórum internacional em que praticamente todos os Estados estão presentes e discutem os principais assuntos da agenda internacional.

A ONU poderia ser vista como um microcosmo da política internacional, refletindo as normas e aspirações, os constrangimentos e as capacidades, os interesses e as políticas que compõem o sistema internacional (DIXON, 1981, p. 52). Portanto, as Nações Unidas seriam a única entre as organizações internacionais em que cada membro tem um voto na AGNU.

Entretanto, as opiniões acerca dessa metodologia não são consensuais na literatura. Para Dixon (1981) a AGNU seria apenas uma arena passiva em relação à interação dos Estados enquanto para Kennedy (2006) essas votações seriam meramente simbólicas, não sendo, portanto, uma demonstração dos alinhamentos dos países. 
Ademais, não se tem como saber precisamente se os votos dos Estados na AGNU seriam uma simples expressão das preferências desses atores internacionais - o que faria das votações na AGNU uma medida confiável da convergência de posições entre os Estados bem como de suas diretrizes gerais de política exterior - ou também poderiam ser um reflexo dos incentivos econômicos entre os Estados, algo já abordado pelo primeiro capítulo dessa tese.

Keohane (1967), em seu texto sobre a influência política na AGNU, destaca que enfatizar apenas os padrões de votação na AGNU não forneceria um conhecimento completo da política desse órgão e, consequentemente, das orientações gerais das políticas externas dos Estados bem como de seus alinhamentos no sistema internacional.

$\mathrm{O}$ autor completa apontando que uma análise estatística apurada e sofisticada indicaria alinhamentos e poderia fornecer pistas sobre os processos de barganha que levaram a eles, mas não trariam uma informação detalhada e relevante sobre esses processos internos ao órgão.

Dessa maneira, se membros individuais podem afetar os processos políticos da AGNU, definidos por Keohane (1967) como interações entre delegações e secretariado por meio das quais chegam-se às decisões da AGNU, então é possível que esses membros causem impacto sobre as escolhas da assembleia. Sendo assim, a política interna da AGNU poderia, em última análise, determinar sobre o que é votado e, portanto, focar apenas nos padrões de votação poderia ignorar o retrato maior acerca da política internacional e da própria ONU.

Entretanto, apesar dessas possíveis inconsistências empíricas, muitos pesquisadores tem utilizado esses dados para determinar alguns comportamentos dos Estados no plano internacional e, assim tentarem compreender elementos mais amplos da política internacional, já que não se dispõe de outras possibilidades, pois não existe, no sistema internacional, nenhuma outra organização ou foro em que todos Estados possam votar de maneira regular sobre os diferentes temas da agenda internacional.

Lijiphart (1963), Marín-Bosch (1998) e Selcher (1978) usam as votações na AGNU para avaliar a posição dos países apenas em temas multilaterais em seus alinhamentos regionais enquanto Thacker (1999), Tomlin (1985) e Voeten (2000) empregam essas votações como indicadores da orientação mais geral da política externa dos Estados.

A Assembleia Geral das Nações Unidas, portanto, ainda seria o único fórum em que um grande número de Estados se encontra e vota em bases regulares sobre assuntos 
concernentes à comunidade internacional. Portanto, o estudo dessa votação em um longo período de tempo e sobre diferentes áreas pode revelar possíveis mudanças nos comportamentos dos Estados no sistema internacional (VOETEN, 2000, p. 151-2) bem como sobre modificações no campo das políticas externas nacionais.

Em seu estudo, Tomlin (1981) procurou examinar a validade de indicadores que recorreram às votações na AGNU, fazendo os seguintes questionamentos: em que medida a semelhança entre os votos nessa instância pode ser usada transplantada para descrever as relações entre os Estados no sistema internacional? As coalizões formadas na Assembleia seriam um indicador válido da aliança entre os Estados na política internacional.

Para responder as essas questões, utilizou-se da análise do comportamento dos Estados "negros" africanos na década de 60 na AGNU e no subsistema africano. Em suas análises utilizou-se, para medir o comportamento na AGNU, o índice de concordância proposto por Lijphart (1963), enquanto para o comportamento no subsistema africano empregou os dados do AFRICA (The African Foreign Relations and International Conflict Analysis que descreve, por meio de fontes africanas, o comportamento de 32 Estados "negros" africanos entre 1964-66). Com isso, o autor formula uma correlação entre esses últimos e as posições nas decisões na AGNU.

Tomlin (1981) conclui que o comportamento nas votações na AGNU poderia representar um indicador válido das orientações dos Estados face à rivalidade entre as superpotências da Guerra Fria.

Já Voeten (2000), em seu artigo que seria uma prévia de sua pesquisa mais ampla lançada em 2012, investiga a validade de uma série de contribuições teóricas ao estudo das relações internacionais que utilizaram a análise das votações na AGNU nos períodos da Guerra Fria (1946-88) e pós-Guerra Fria para explicar os alinhamentos e as políticas externas nacionais.

O autor busca responder às seguintes questões: (1) a clivagem Leste-Oeste deixou de ser relevante após o final da ordem bipolar, ou seja, as alianças atualmente seriam mais fluídas e o mundo seria multipolar, algo que poderia ser evidenciado a partir das votações na AGNU? (2) Quais seriam os determinantes do comportamento dos Estados nas votações e esses estariam coerentes quando se analisam temas diversos? (3) As linhas divisórias da política internacional teriam sido mudadas completamente desde o fim da Guerra Fria ou parte do conflito bipolar continuou após seu fim? 
Essas questões são respondidas por meio da análise de todas as votações ocorridas na AGNU entre 1946-1988 e 1991-96, chegando à conclusão de que o final da ordem bipolar não alterou de forma relevante o comportamento dos Estados na AGNU, já que esse comportamento ainda seria significativamente determinado pelas posições dos países durante o período da Guerra Fria. Ademais, a posição dos Estados seria estável nos períodos e temas analisados. Dessa maneira, Voeten (2000, p. 2013) acredita que "se a política global tornou-se multidimensional e as alianças se tornaram ad hoc e centradas em temas específicos, isso não pode ser constatado no comportamento dos países na Assembleia Geral da ONU”. Além disso, os dados demonstrariam que a clivagem Leste-Oeste da ordem bipolar permaneceu no período seguinte, o que refutaria a hipótese de que a clivagem Norte-Sul teria se tornado mais relevante que o conflito Leste-Oeste, como é colocado por muitos analistas internacionais.

Para chegar a esses resultados, Voeten (2000) tem como variável dependente o grau de alinhamento com as posições do Ocidente, mostrando que o nível de riqueza (PIB per capita) e o tipo de regime seriam os principais determinantes, pois quanto mais rico e mais democrático é um país, mais tenderia a votar conforme o Ocidente. Isso seria ainda reforçado ainda mais pelo fato de que conforme os países foram tornando-se mais democráticos a partir de 1989 mais passaram a votar de acordo com bloco ocidental. Entretanto, o efeito da variável democracia variaria conforme os temas em votação, sendo mais relevantes em questões relacionadas ao colonialismo, aos direitos humanos e a questões consideradas importantes pelos Estados Unidos (VOETEN, 2000, p. 209).

Dessa maneira, os trabalhos desses autores supracitados contribuiriam para justificar a utilização da AGNU como parâmetro para análise dos alinhamentos entre os países no sistema internacional bem como da orientação geral das políticas externas nacionais.

\subsection{Metodologia:}

Para comprovar hipótese de pesquisa principal dessa tese de doutorado, a saber: as estratégias de incremento das relações bilaterais geram o aumento do apoio dos países beneficiados aos beneficiadores no plano multilateral. Dessa maneira, conforme a literatura explorada no primeiro capítulo dessa pesquisa, buscar-se-á explicar os 
determinantes da convergência de votos em foros multilaterais. Para isso, será utilizada análise de dados em painel.

A vantagem dos modelos de dados em painel em relação aos modelos de corte transversal, segundo Hsio (1986), é a possibilidade de se controlar a heterogeneidade presente nos indivíduos e aumentar a precisão das estimações (CAMERON; TRAVEDI, 2005).

Com vistas a verificar o efeito das variáveis de interesse serão feitas três estimações distintas. Em primeiro lugar, estimaremos por meio do pooled regression model (POLS). Depois por meio do modelo de efeitos aleatórios (EA). E por fim, por meio do modelo de efeitos fixos (EF), que permite estimadores consistentes na presença de heterogeneidade não observada correlacionada com outros regressores.

Posteriormente, serão realizados os testes necessários para verificar qual é o modelo que melhor se adéqua à natureza dos dados analisados, visando maximizar a eficiência do modelo, dado que os coeficientes sejam consistentes.

No modelo básico do POLS, o estimador considera todas as informações como unidades transversais, ignorando o elemento temporal. Dessa maneira, o POLS considera que temos em nosso banco de dados $N$ x $T$ unidades. Apesar ser um método frequentemente utilizado, existe um problema em sua utilização relacionado à validade da hipótese de que não se tem informação do erro idiossincrático que esteja correlacionado com as variáveis explicativas. Sendo assim, ao desconsiderar a temporalidade do banco de dados, o modelo não permite o controle para heterogeneidade específica ( $c i$ ), causando inconsistência e viés nos estimadores caso a heterogeneidade esteja correlacionada com algum dos regressores, ou seja, exista algum regressor endógeno. Ademais, POLS requer exogeneidade fraca, ou seja, que os regressores e o erro composto vit não sejam correlacionados no mesmo período ${ }^{30}$.

Também exige posto completo para evitar multicolineariedade perfeita, assim como os outros dois modelos a serem apresentados a seguir.

$$
\begin{aligned}
& \text { Modelo POLS } \\
& Y_{i t}=\alpha+\boldsymbol{X}_{i t} \boldsymbol{\beta}+\boldsymbol{\varepsilon}_{i t}
\end{aligned}
$$

\footnotetext{
${ }^{30}$ Os modelos de efeitos fixos e efeitos aleatórios consideram a presença de heterogeneidade específica, que são consideradas como parte do intercepto no primeiro e parte do erro no segundo e, requerem, diferentemente do modelo de POLS, exogeneidade estrita. Isso implica que o termo de erro deve ser não correlacionado com qualquer um dos regressores em qualquer período de tempo, assumindo que o erro tem média zero condicional nos valores passados, presentes e futuros dos regressores (CAMERON; TRAVEDI, 2005).
} 


$$
\mathrm{E}\left(\boldsymbol{\varepsilon}_{i t} / \mathrm{x}\right)=0 ; \boldsymbol{\varepsilon}_{i t} \sim \operatorname{IID}\left(0, \sigma^{2}\right)
$$

A estimação por POLS permite o controle dos efeitos anuais por meio da utilização de dummies de ano $\left(\mathrm{d}_{\mathrm{s}}\right)$, como também por dummies de grupos específicos de indivíduos $\left(\mathrm{d}_{\mathrm{j}}\right)$. Assim, o modelo POLS torna-se:

Modelo POLS com dummies de ano e de grupos especificos

$$
\begin{aligned}
& Y_{i t}=\alpha+\boldsymbol{X}_{i t} \boldsymbol{\beta}+\gamma \mathbf{d}_{\mathbf{s}}+\lambda \mathbf{d}_{\mathbf{j}}+\varepsilon_{i t} \\
& \mathrm{E}\left(\varepsilon_{i t} / \mathrm{x}\right)=0 ; \varepsilon_{i t} \sim \operatorname{IID}\left(0, \sigma^{2}\right)
\end{aligned}
$$

O modelo de efeitos aleatórios (EA) tratará a heterogeneidade específica não observada ( $c i$ ) como uma variável aleatória, distribuída independentemente dos regressores e com variância homocedástica. Nesse modelo, o efeito específico torna-se parte do erro e, portanto, não pode ser correlacionado com nenhum regressor em todos os períodos, caso contrário todos os estimadores serão inconsistentes ao violar uma das hipóteses Gauss-Markov da estimação por $O L S$. Já pela hipótese da exogeneidade estrita, o erro $u_{\text {it }}$ não deve ser correlacionado com os regressores nem com o efeito específico em qualquer período de tempo.

O modelo de efeitos aleatórios é estimado por generalized least squares (GLS), quando a matriz de variância-covariância é conhecida. A estimação da feasible generalized least squares (FGLS) é usada quando esta matriz é desconhecida.

\section{Modelo Efeitos Aleatórios:}

$Y_{i t}=\alpha+\boldsymbol{X}_{i t} \boldsymbol{\beta}+\mathrm{v}_{\mathrm{it}}=\alpha+\boldsymbol{X}_{i t} \boldsymbol{\beta}+\left(\mathrm{c}_{\mathrm{i}}+\boldsymbol{\varepsilon}_{\mathrm{it}}\right)$

onde vit é o erro composto dado por $c i+\varepsilon_{i t}$

$$
\mathrm{E}\left(\boldsymbol{v}_{i t} / \mathbf{X}_{\mathbf{i s}}\right)=0 \text {; para } \forall \mathrm{i} \neq \mathrm{s}
$$

$v_{i t} \sim \operatorname{IID}\left(0, \sigma^{2}\right)$

A análise de efeitos fixos (EF), por sua vez, examina diferentes interceptos para os indivíduos, assumindo que as inclinações são constantes, assim como a variância. $\mathrm{O}$ efeito específico $c i$ não é tratado mais como uma variável aleatória como no modelo de efeitos aleatórios, mas como um parâmetro a ser estimado. Dessa forma, ao contrário do $E A$, o modelo $E F$ permite que o efeito específico $c i$ seja correlacionado com os regressores $\mathbf{X}_{\mathbf{i t}}$. A estimação do EF requer exogeneidade estrita, ou seja, que todos os regressores não sejam correlacionados com o erro $u_{i}$ em todos os períodos. 
Ao fazer a estimação por EF, é necessário recorrer a uma das técnicas de transformação para eliminar a heterogeneidade. As mais usuais são as primeiras diferenças e a within transformation.

Modelo de Efeitos Fixos:

$Y_{i t}=\alpha+c i+\boldsymbol{X}_{i t} \boldsymbol{\beta}+\boldsymbol{\varepsilon}_{\mathbf{i t}}$

Transformação para eliminar o ci: $Y_{i t}-Y m=\left(\boldsymbol{X}_{i t}-\boldsymbol{X m}\right) \boldsymbol{\beta}+\left(\boldsymbol{\varepsilon}_{\mathrm{it}}-\boldsymbol{\varepsilon}_{\mathrm{m}}\right)$

$\mathrm{E}\left(\varepsilon_{i t} / \mathbf{X}_{\mathbf{i s}}, c i\right)=0$; para $\mathrm{i}_{\mathrm{i}} \neq \mathrm{s}$

$\varepsilon_{i t} \sim \operatorname{IID}\left(0, \sigma^{2}\right)$

Após a realização destas estimações, serão os testes necessários para confirmar quais são os estimadores consistentes e, dentre estes, quais são os mais eficientes. Conforme exposto, caso exista heterogeneidade não observada não correlacionada com algum regressor, os estimadores de efeitos fixos e aleatórios são consistentes, sendo o último mais eficiente. Caso a heterogeneidade seja correlacionada com algum regressor, o primeiro é o único consistente. Desta forma, no final da análise realizaremos testes de Breusch-Pagan para verificar a presença de heterogeneidade específica e de Hausman para verificar a correlação entre esta e os regressores.

O teste de Hausman (1978) é utilizado para comparar os modelos EA e EF sob a hipótese nula de que a heterogeneidade não observada é não correlacionada com os regressores do modelo. Se Ho é verdadeira, os estimadores de EA são consistentes e eficientes e os de EF são consistentes. Caso a hipótese correta seja a alternativa, então o modelo EA gera estimadores inconsistentes e o EF consistentes. Portanto, se a hipótese nula é verdadeira, é melhor utilizar o modelo EA, pois estima menos parâmetros em relação ao EF. Caso a hipótese alternativa seja verdadeira, prefere-se o modelo EF, que é o único a produzir estimativas consistentes.

Ademais, uma importante limitação do método de efeito fixo é a impossibilidade de estimar o efeito de variáveis constantes no tempo. Portanto, caso o Teste de Hausman (1978) indique uma não diferença entre os estimadores de $E F$ e $E A$, além do último ser o mais eficiente, permite também a inclusão de variáveis constantes no tempo. 
A amostra analisada cobre as 1.158 resoluções da Assembleia Geral das Nações Unidas entre os anos de 1995 e 2010. O banco de dados possui além dessas informações, quatro tipos de variáveis: políticas, comerciais, econômicas e geográficas, algumas delas utilizadas como controle nas estimações, cujo modelo pode ser explicado pelo seguinte quadro:

Figura 27 - Modelo da convergência de votos

\begin{tabular}{|c|c|c|}
\hline $\begin{array}{l}\text { Participação do Brasil } \\
\text { nas exportações totais } \\
\text { de cada país africano. } \\
\text { Participação } \\
\text { brasileira nas } \\
\text { importações totais de } \\
\text { cada país africano. } \\
\text { Número de projetos } \\
\text { de cooperação } \\
\text { brasileiros com cada } \\
\text { país africano. }\end{array}$ & $\begin{array}{l}\text { PIB per capita de } \\
\text { cada país africano } \\
\text { Convergência de } \\
\text { votos EUA e os } \\
\text { países africanos. } \\
\text { CPLP } \\
\text { País colonizador }\end{array}$ & $\begin{array}{l}\text { Convergência de } \\
\text { votos entre o Brasil e } \\
\text { países africanos. }\end{array}$ \\
\hline
\end{tabular}

A equação básica a ser estimada a partir desse modelo pode ser resumida da seguinte maneira:

$$
\begin{aligned}
& \text { Votação }=\alpha+\beta_{1}(\operatorname{coop})_{i t}+\beta_{2}(\exp \text { ou imp })_{i t}+\beta_{3}(\text { Pibpe })_{i t}+ \\
& \beta_{4}(\text { EUA2 })_{i t}+\beta_{5}(\text { CPLP })_{i t}+\beta_{6}(\text { Lula })_{i t}+\beta_{7}(\text { col })_{i t}+\varepsilon_{i t}
\end{aligned}
$$


na qual $i$ refere-se ao país africano, $t$ ao ano e $\alpha$ e $\varepsilon_{\text {it }}$ são, respectivamente, a constante e o erro idiossincrático, coop e exp ou imp são as variáveis independentes de interesse e votação é variável dependente de interesse.

A variável votação, indica a porcentagem de convergência de votos entre o Brasil e cada um dos países do continente africano, entre os anos de 1995 e 2010, excluindo as abstenções ${ }^{31}$.

O fortalecimento das relações bilaterais será medido por meio de três variáveis independentes:

- número de projetos de cooperação celebrados pelo Brasil com o continente africano entre os anos de 1995 a 2010, chamada de COOP;

- participação do Brasil nas exportações totais de cada país africano entre os anos de 1995 a 2010, chamada de EXP;

- participação do Brasil nas importações totais de cada país africano entre os anos de 1995 a 2010, chamada de IMP.

Essas variáveis foram escolhidas, pois seriam a maneira de um país emergente “comprar" votos na AGNU, já que a sua capacidade de fornecer ajuda internacional em dinheiro é limitada, diferentemente dos EUA, país foco dos estudos de compra de votos em foros multilaterais, cuja capacidade de doação é bem maior que a de um país emergente.

\subsection{Dados:}

Para o cálculo da variável dependente, foram utilizados os dados colhidos por Anton Strezhnev e Erik Voeten (2012), que formularam um banco de dados com os registros de 4.600 votações realizadas na AGNU entre os anos de 1946-2012. Após recolher os votos semelhantes na AGNU entre o Brasil e cada um dos 53 países africanos entre os anos de 1995 e 2010, será calculada a porcentagem de convergência entre esses parceiros a partir do total de vezes que os mesmos votaram em resoluções da $\mathrm{AGNU}^{32}$.

\footnotetext{
${ }^{31}$ Foram excluídas as abstenções, pois ao analisar a porcentagem de convergência quando são consideradas abstenções, percebeu-se um alto índice de convergência na maior parte dos casos, chegando em vários anos a $100 \%$. Sendo assim, não haveria um alto grau de variação para que pudessem ser percebidas a relação com as variáveis escolhidas.

${ }^{32}$ Isso foi necessário, pois os países africanos nem sempre votam em todas as resoluções devido a questões de dívida de sua contribuição anual para a ONU - o que faz com que o país devedor seja
} 
Com relação à terceira variável independente - cooperação -, os números foram calculados a partir da quantidade de projetos de cooperação bilateral assinados entre o Brasil e cada um dos países africanos entre 1995 e 2010.

Os projetos de cooperação foram selecionados, pois conforme a literatura disponível sobre "compra de votos" na AGNU, os Estados utilizariam a ajuda internacional para angariar o apoio dos países beneficiados nas votações na Assembleia.

As variáveis relativas ao comércio bilateral (EXP e IMP) foram calculadas a partir da porcentagem das exportações e importações de cada um dos 53 países africanos em relação ao Brasil sobre as exportações e importações totais desses 53 Estados em cada um dos anos abrangidos por essa pesquisa.

Optou-se por verificar a participação do Brasil nos números relacionados ao comércio da África, pois, por meio desses, será possível mensurar a relevância brasileira para o continente em questão, algo que poderia influenciar nas decisões de voto dos países africanos na AGNU e, consequentemente, o possível apoio às demandas brasileiras nesse órgão.

Uma das variáveis intervenientes escolhidas foi o PIB per capita de cada país africano, chamado de PIBpercapita (ano-base 2005) com o objetivo de controlar a possível influência do grau de desenvolvimento sobre as decisões de voto. Essas informações foram recolhidas a partir dos dados disponibilizados pela Conferência das Nações Unidas para o Desenvolvimento (UNCTAD) para cada um dos países da África.

Também foi utilizada convergência de votos entre os países africanos e os EUA, excluindo as abstenções, devido ao mesmo motivo explicitado para o caso brasileiro calculada da mesma maneira que votação -, chamada de EUA2, entre os anos de 1995 a 2010, para, dessa maneira, retirar o possível efeito da convergência entre os países e os EUA - principal potência internacional - dos resultados.

A outra variável interveniente escolhida foi o pertencimento à CPLP, pois, verificou-se pelos dados recolhidos no tocante ao comércio e à cooperação que o pertencimento a essa comunidade tem um peso importante na política africana brasileira, já que esses países possuem destaque no comércio bilateral e nos projetos de cooperação técnica, essa variável é uma dummy chamada CPLP, sendo que os países não-pertencentes à CPLP serão o número 0 e os pertencentes o número 1 .

impedido de votar -, de carência de pessoal para estar presente em todas votações ou conflitos internos em seus países. 
A variável interveniente seguinte diz respeito à colonização. Como grande parte dos países africanos foram colonizados, escolhemos a construção de uma dummy que levasse em conta o país colonizador. Dessa forma, os países que não foram colonizados tem o número zero, as ex-colônias britânicas o número 1, as ex-colônias francesas o número 2, as ex-colônias belgas o número 3, as ex-colônias espanholas o número 4, as ex-colônias italianas o número 5 , as ex-colônias alemãs o número 6 e as ex-colônias portuguesas o número 7 .

A última variável interveniente escolhida, chamada Lula, foi uma dummy construída para ver o que aconteceria com os dados a partir da entrada de Lula na presidência, dessa maneira, os dados relativos aos anos de 1995 a 2002, receberam o número 0, enquanto os dados relativos aos anos de 2003 a 2010, receberam o número 1.

Abaixo seguem a descrição das variáveis (Tabela 2) e suas respectivas estatísticas descritivas (Tabela 3).

Tabela 2 - Descrição das variáveis

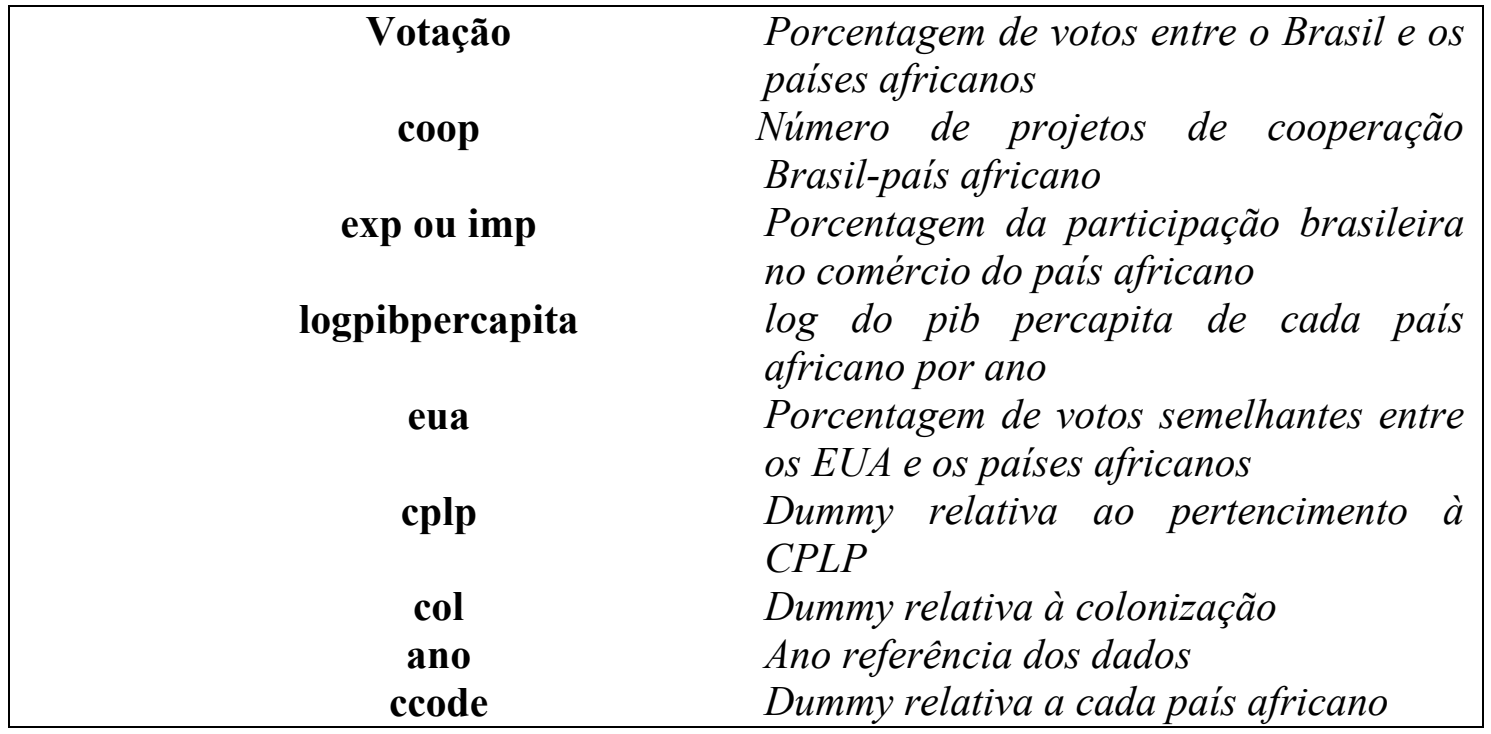

Tabela 3 - Estatísticas Descritivas das variáveis

\begin{tabular}{|c|c|c|c|c|c|}
\hline $\begin{array}{l}\text { Variáveis } \\
\text { Contínuas }\end{array}$ & Média & Mediana & $\begin{array}{l}\text { Desvio- } \\
\text { Padrão }\end{array}$ & Mínimo & Máximo \\
\hline Vot2 & 84.665 & 85.938 & 7.689 & 21.428 & 100 \\
\hline Coоp & 0.469 & 0.000 & 1.501 & 0 & 14 \\
\hline $\operatorname{Exp}$ & 0.817 & 0.035 & 2.975 & 0 & 54.558 \\
\hline $\operatorname{Imp}$ & 1.550 & 0.659 & 2.571 & 0 & 28.446 \\
\hline Logpibpercapita & 6.644 & 6.265 & 1.122 & 4.443 & 9.907 \\
\hline Eua2 & 78.550 & 78.947 & 7.948 & 21.428 & 100 \\
\hline $\begin{array}{l}\text { Variáveis } \\
\text { Dummies }\end{array}$ & Frequencia & 0 & 2 & 4 & 6 \\
\hline
\end{tabular}




\begin{tabular}{lllllllll}
\hline cplp & 752 & 96 & & & & & & \\
col & 32 & 288 & 320 & 48 & 16 & 32 & 32 & 80
\end{tabular}

Portanto, a relação entre essas variáveis indicaria que a convergência de votos entre um país e uma região/país na AGNU pode ser explicada a partir da participação desse país no comércio dessa região/país e do número de projetos de cooperação entre um país e essa região/país. Entretanto, essa relação pode ser afetada por fatores como o PIB per capita, a convergência com os EUA, país que mais investe na "compra de votos", conforme apontado pela literatura acerca do tema, o pertencimento à CPLP e a fidelidade ao país colonizador.

\subsection{Apresentação dos dados}

Nessa seção será feita a apresentação das variáveis dependente e independente para o conjunto do continente africano de maneira a apresentar as possíveis inferências que podem ser feitas a partir da simples interpretação dos dados empíricos. Na seção posterior, serão apontados os resultados estatísticos do modelo proposto.

Após a coleta e análise dos dados relativos às exportações e importações africanas para o Brasil, percebeu-se que a participação brasileira no comércio africano é muito baixa, representando, no período analisado cerca de apenas $1,76 \%$ das importações africanas. Apesar de ter crescido a partir dos anos 2000, sendo que essas começaram a decrescer a partir de 2006, conforme demonstra o gráfico a seguir.

Figura 28 - Evolução da participação brasileira nas importações africanas 


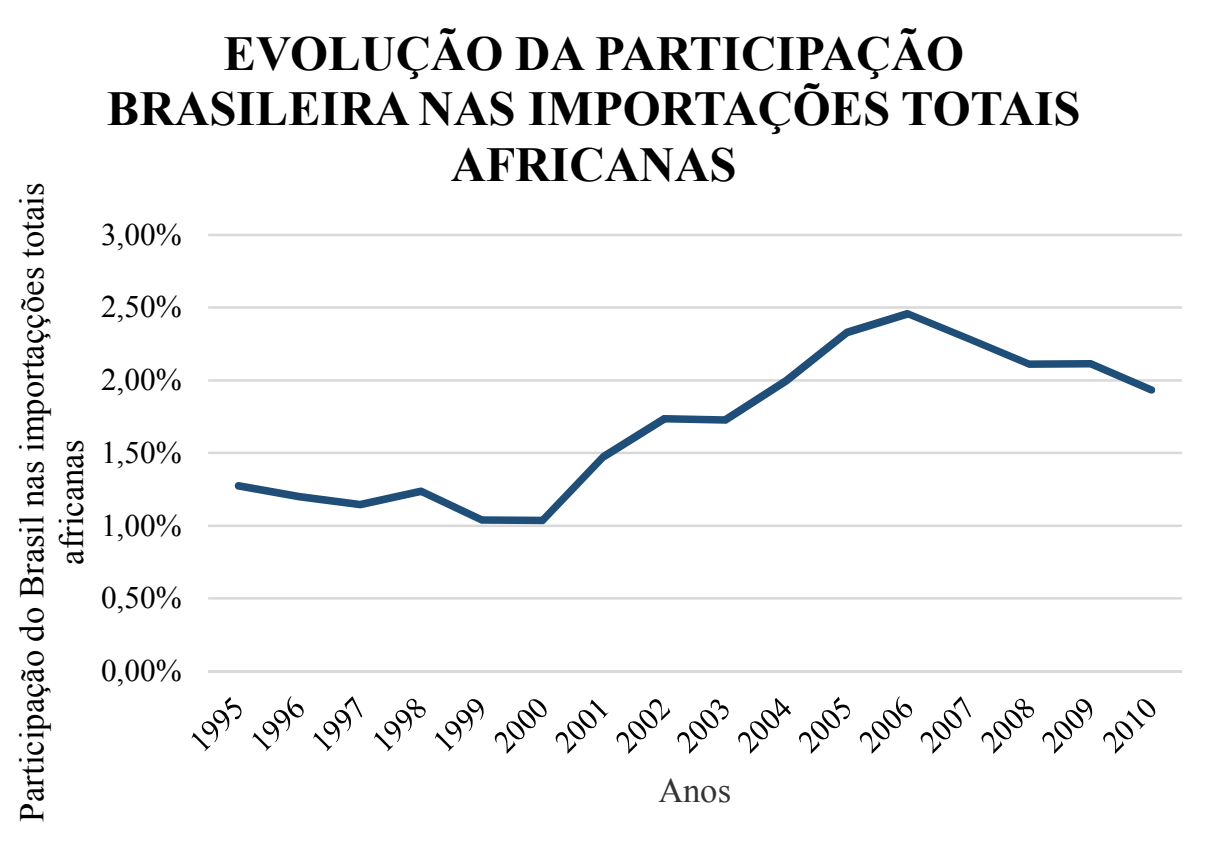

Fonte: Unctad. Elaboração Própria.

Ao analisar essa evolução por governos, ficou claro o crescimento da participação brasileira nas importações totais africanas entre os governos FHC e Lula, com um aumento de $110,18 \%$ entre os dois governos, passando de 1,01\% no governo FHC para 2,12\% no governo Lula, conforme gráfico a seguir:

Figura 29 - Evolução da participação brasileira nas importações africanas por governo 


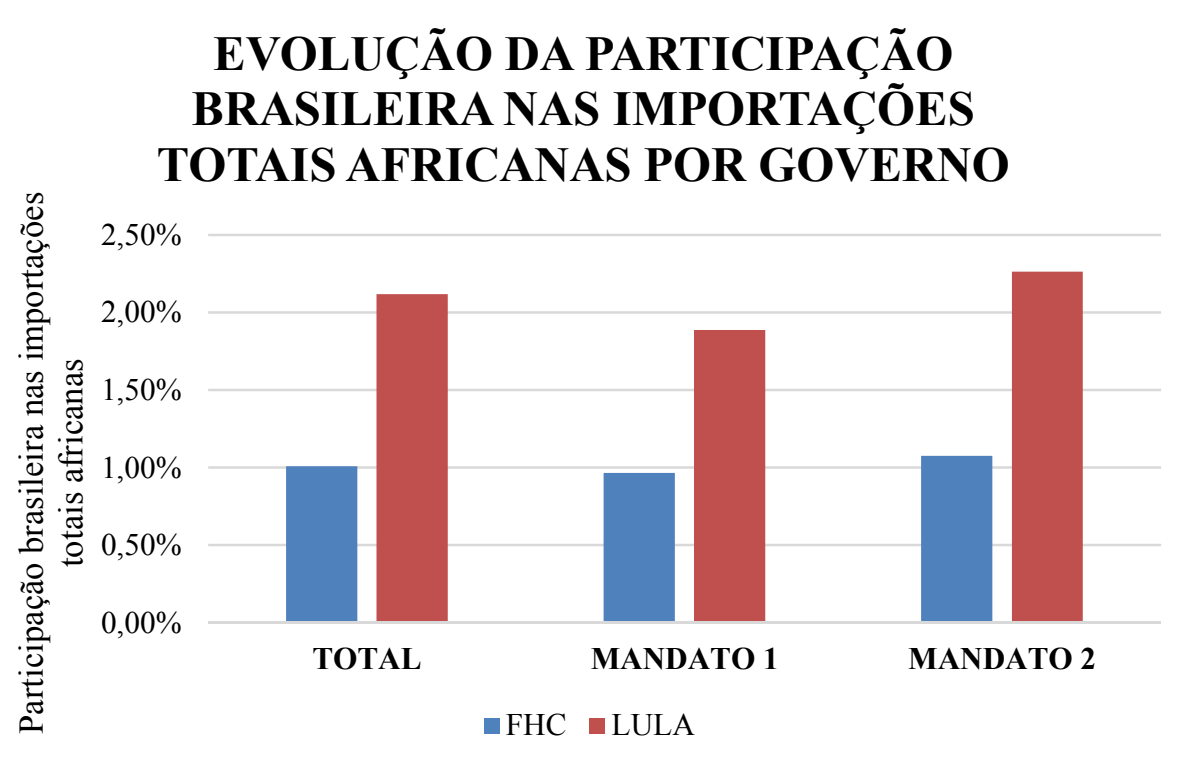

Fonte: Unctad. Elaboração própria.

A participação brasileira nas exportações africanas também não difere muito do cenário analisado em relação às importações, com cerca de 2,024\% entre os anos de 1995 e 2010. Diferentemente da trajetória predominantemente crescente no lado das importações, no que tange à participação brasileira nas exportações totais africanas, o curso não foi constantemente crescente ao longo do período analisado, experimentando momentos de queda e posterior alta a partir do início dos anos 2000.

Figura 30 - Evolução da participação brasileira nas exportações africanas

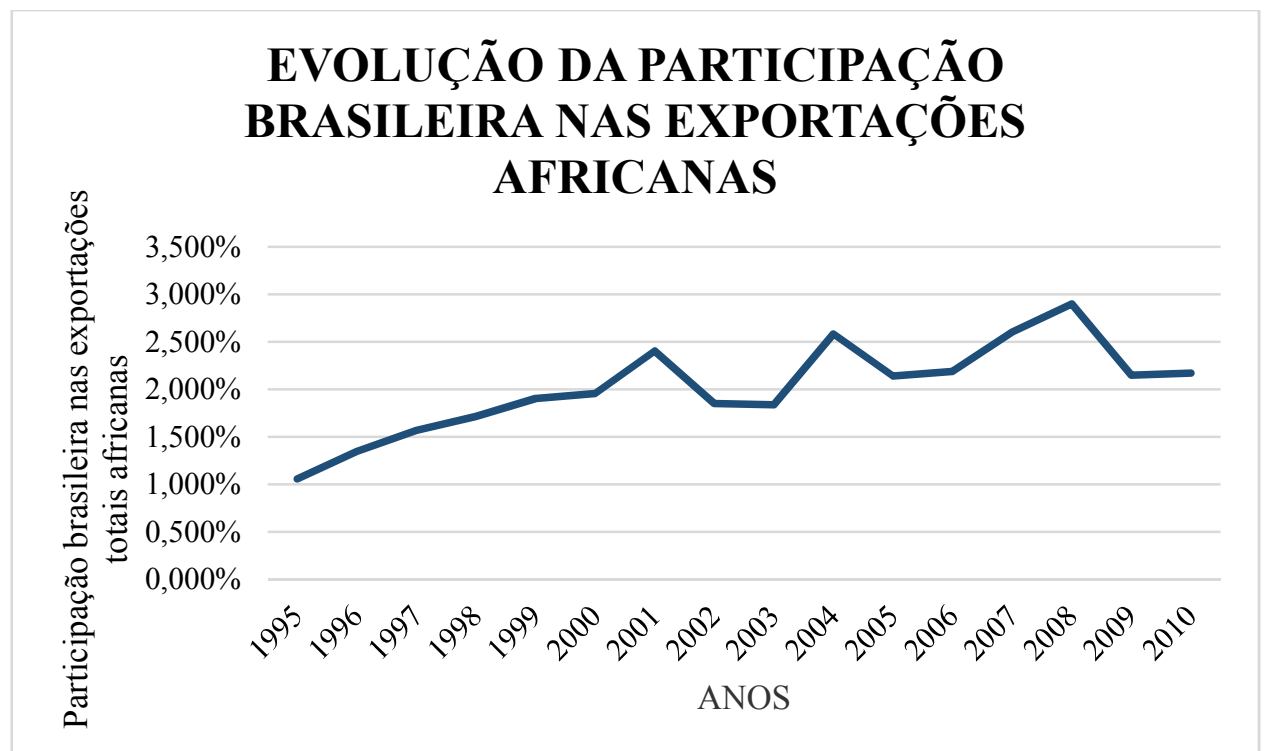

Fonte: Unctad. Elaboração Própria. 
Ao verificar a evolução da participação brasileira nas exportações totais africanas de acordo com o governo, ocorre, assim como no caso das importações, um aumento da participação brasileira nas exportações totais africanas entre os dois governos estudados, apesar desse incremento ser bem menor do que no caso das importações. Entre o governo FHC e o governo Lula, a participação brasileira nas exportações totais africanas cresce cerca de 35,73\%, passando de $1,75 \%$ no governo FHC para 2,38\% no governo Lula.

Figura 31 - Evolução da participação brasileira nas exportações africanas por governo

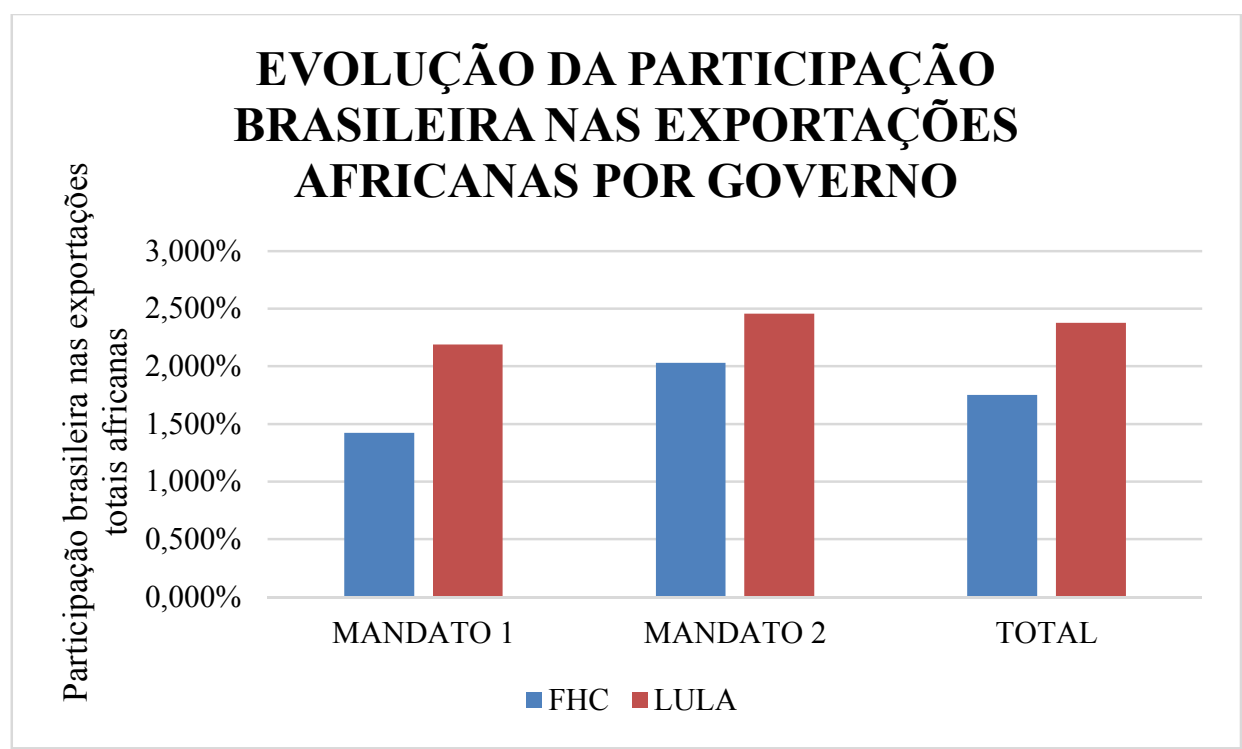

Fonte: Unctad. Elaboração Própria.

Aparentemente, esses dados demonstrariam que, apesar de ocorrido um aumento na participação brasileira nas importações e exportações totais africanas, o Brasil ainda seria um parceiro pouco relevante para o continente africano, o que, por sua vez, não justificaria um aumento da convergência de votos nas votações da AGNU, já que outros países teriam maior relevância do ponto de vista comercial e, portanto, mereceriam maior apoio dos países africanos na Assembleia.

No tocante à cooperação bilateral, a evolução entre os anos de 1995 e 2010 foi significativa, passando de apenas projetos no ano de 1995 para 78 projetos no de 2010 , apesar dessa trajetória ter sofrido alguns reveses ao longo do período, conforme gráfico abaixo. 
Figura 32 - Evolução dos projetos de cooperação bilateral Brasil-África

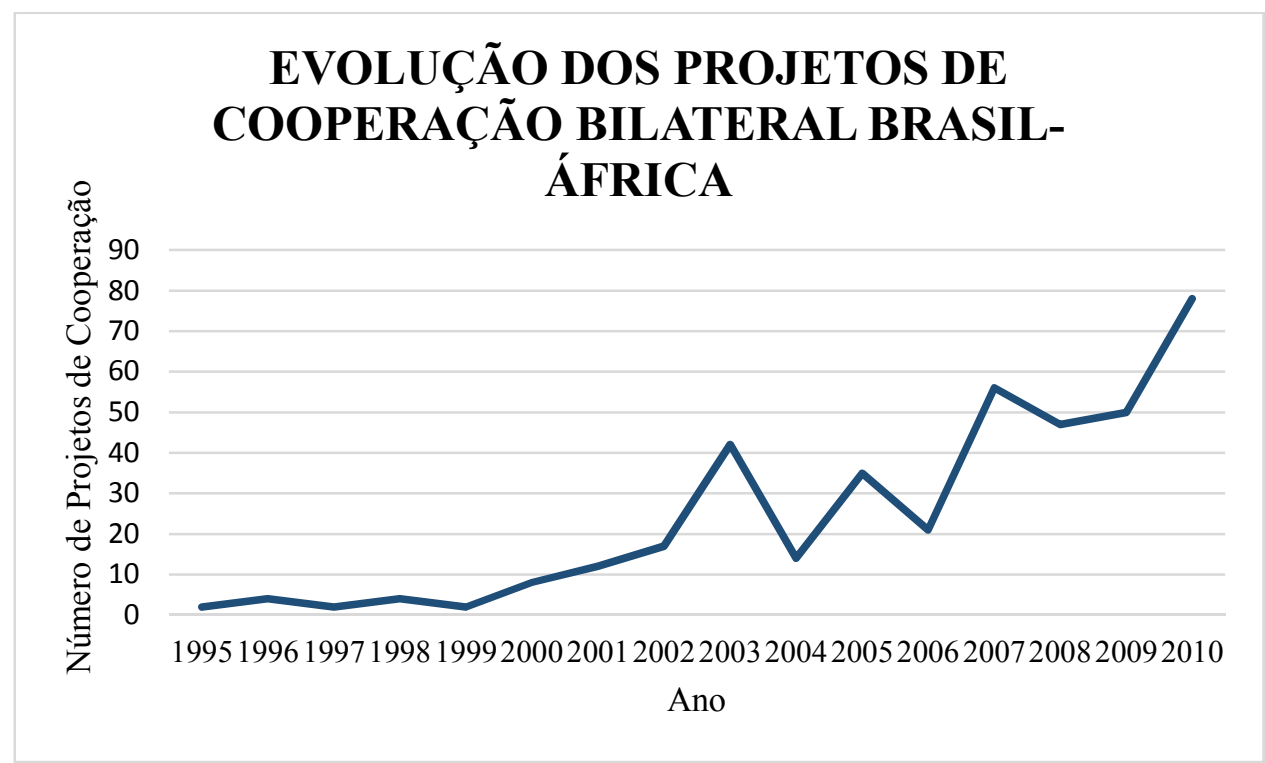

Fonte: DAI-MRE. Elaboração Própria.

O aumento expressivo dos projetos de cooperação bilateral poderá ser de grande valia para essa tese, pois esse poderia contribuir para o aumento da convergência entre o Brasil e os países africanos nas votações na AGNU, conforme aponta a literatura sobre o tema explorada no primeiro capítulo dessa pesquisa.

Ao analisar as votações nas AGNU, percebeu-se um alto grau de convergência entre o Brasil e o continente africano, principalmente quando foram contabilizadas as abstenções (VOT1), chegando em um dos anos a 100\% de convergência, conforme demonstra o gráfico a seguir.

Figura 33 - Evolução da convergência Brasil-África na AGNU por ano 


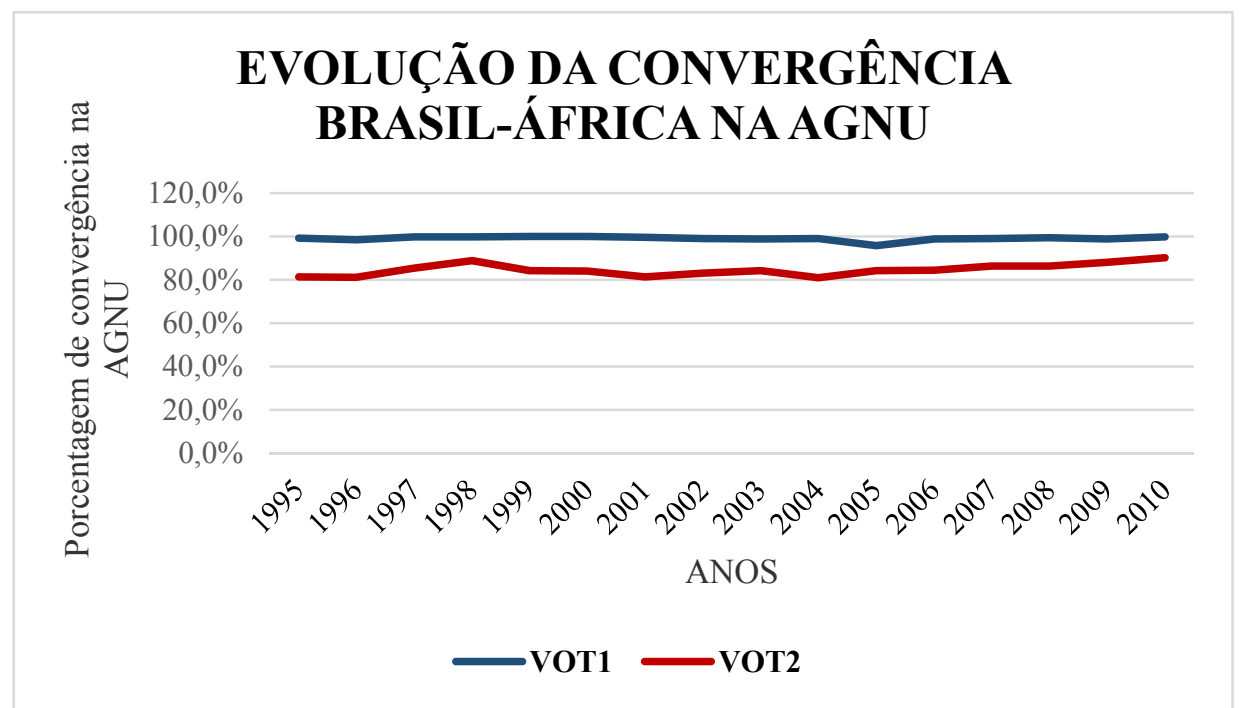

Fonte: ONU, STREZHNEV; VOETEN, 2012. Elaboração Própria.

Esse alto grau de convergência entre o continente africano e o Brasil na AGNU aparentemente poderia prejudicar a comprovação da hipótese dessa pesquisa, já que o aumento na convergência não traria mudanças significativas na orientação geral dos países africanos nas votações na AGNU, já que o ponto de partida já seria bastante alto, ou seja, já existiria uma convergência, o que, portanto, não justificaria, por parte do Brasil a "compra" dos votos africanos. Também devido a isso, só será utilizada a convergência excluindo as abstenções.

Entretanto, conforme apontado pela literatura acerca do tema, uma das justificativas para a "compra" de votos não seria apenas aumentar o apoio de determinados países nos foros multilaterais, mas também para premiar ou recompensar os Estados aliados, impedindo que outros países conquistem a sua lealdade.

No tocante à evolução da convergência de votos entre a África e o Brasil na AGNU entre os dois governos, não houve uma mudança significativa no padrão tradicional de votação entre o Brasil e o continente africano, sendo que, diferentemente das variáveis independentes, houve um leve retrocesso na convergência de votos, incluindo as abstenções (VOT1), de 99,4\% no governo FHC para 98,6\% no governo Lula. Já quando são retiradas as abstenções (VOT2), ocorre um movimento inverso, passando de $83,7 \%$ no governo FHC para $85,6 \%$ no governo Lula, conforme aponta o gráfico abaixo.

Figura 34 - Evolução da Convergência Brasil-África na AGNU por governo 


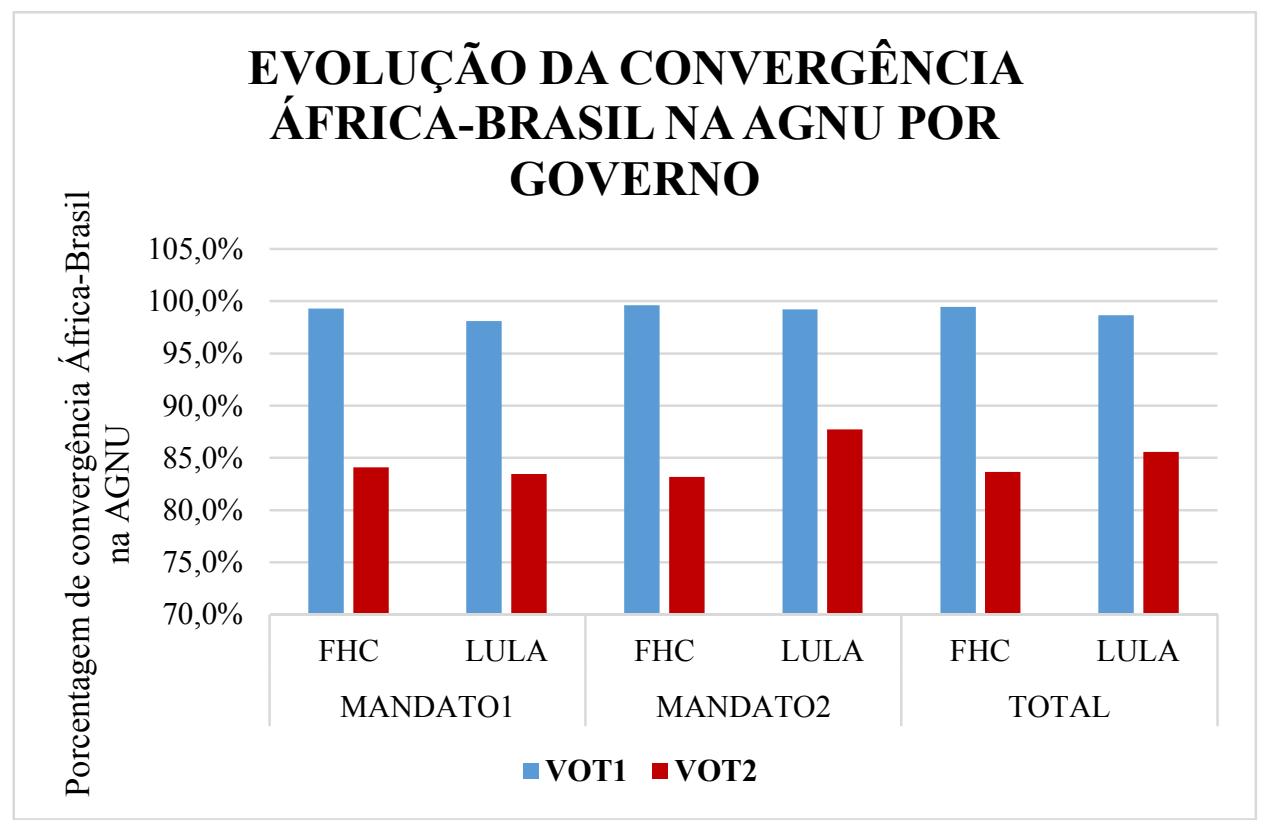

Fonte: ONU, STREZHNEV; VOETEN, 2012. Elaboração Própria.

Outro fato interessante, está relacionado aos países que possuem maior convergência com o Brasil em cada governo. Chamou a atenção que nos dois governos, os principais aliados não seriam países com os quais o Brasil teria um relacionamento bilateral forte ou antigo. Em ambos governos, o país que apresenta maior convergência é a ilhas Seychelles, chamando a atenção que também em ambos, Angola, um parceiro tradicional brasileiro, aparece entre os países que tem menor convergência. Esse dado é interessante, mas não tão significativo, já que a convergência é alta com todos países africanos, mesmo em relação aos países em que a semelhança de votos é menor.

Essa evolução entre os dois governos estudados demonstraria, de maneira aparente, portanto, que os esforços de fortalecimento das relações bilaterais empreendidos pelo governo Lula não modificaram de maneira significativa a convergência Brasil-África na AGNU, muito pelo fato, já apontado anteriormente, de que essa convergência já seria alta quando do início do governo Lula, o que não justificaria as estratégias lulistas de incremento do relacionamento brasileiro com o continente africano com propósito de angariar o apoio desses países nos foros multilaterais, devendo, portanto, ter uma outra lógica, a qual deve ser explorada por pesquisas futuras.

Dessa maneira, aparentemente, a análise descritiva dos dados apontou que as variáveis independentes selecionadas - participação brasileiras nas importações e exportações totais e o número de projetos de cooperação - não teria provocado alterações significativas nos padrões de votação da África em relação ao Brasil, o que 
frustraria a hipótese de que a utilização dessas estratégias poderia modificar o padrão de votação de Estados nos foros multilaterais. Conforme mencionado anteriormente, esse possível resultado dever-se-ia ao fato de que a convergência entre o Brasil e o continente africano já seria alta desde antes da utilização dessas novas estratégias, o que diminuiria a sua capacidade de influenciar na modificação dos padrões de votos africanos na AGNU.

Na seção seguinte, iremos explorar essas variáveis descrita na presente seção por meio do modelo estatístico já descrito anteriormente para verificar se a mesma nos fornece conclusões mais precisas sobre a relação entre as variáveis escolhidas, já que, de maneira inferencial, isso não teria sido possível.

\subsection{Resultados}

Após a realização dos testes para verificar qual o modelo de estimação seria mais consistente para a comprovação da hipótese de pesquisa, os resultados dos coeficientes foram semelhantes para todas as variáveis em todos os modelos testados.

A partir dos resultados percebeu-se, em todos os modelos, uma relação positiva entre as variáveis cooperação e importação e a convergência de votos, ou seja, a cooperação e o aumento da participação brasileira nas importações africanas aumentariam a similaridade de votos entre o Brasil e os países africanos. Já nos casos das variáveis exportação e Lula, encontrou-se uma relação negativa com a convergência de votos, ou seja, o aumento da participação brasileira nas exportações africanas e a partir do governo Lula diminuíram a convergência de votos na AGNU entre os países africanos e o Brasil.

Como todos os modelos apresentaram relações semelhantes entre as variáveis, a melhor maneira para a escolha do modelo adequado seria o seu grau de significância e, partir dos números, o modelo que apresentou-se mais significante o modelo de efeitos aleatórios $(E A)$, pois teria sido aquele em que encontramos a maior significância para as variáveis escolhidas.

Com o modelo escolhido, realizamos os cálculos relativos às variáveis escolhidas e foram encontrados os seguintes coeficientes de correlação com a convergência de votos na AGNU, resumidos na tabela 4.

Tabela 4 - Coeficientes de Correlação 


\begin{tabular}{lcc} 
vot200 & Coeficiente \\
\hline coop & .3774865 \\
imp100 & .2609045 \\
lula & & -2.155566 \\
logpibperc $\sim a$ & 1.215576 \\
eua200 & & .5778057 \\
cplp & & -1.730221 \\
col & & \\
& & \\
& 1 & -1.48046 \\
& 2 & -.7673221 \\
& 3 & -3.462226 \\
& 4 & -4.006992 \\
& 5 & -1.465307 \\
& 6 & -1.821095 \\
& 7 & $($ omitted)
\end{tabular}

A partir dos resultados dos coeficientes da regressão em que são considerados os dados relativos à importação. Podemos afirmar existe uma relação positiva entre a cooperação e a convergência de votos na AGNU, ou seja, de que um acordo de cooperação gera um aumento de 0.37 ponto percentual na similaridade de votos entre o Brasil e os países africanos. Essa relação também é encontrada em relação à importação, ou seja, o aumento de $1 \%$ na importação gera um aumento de 0.26 ponto percentual na convergência de votos entre os países africanos e o Brasil.

As variáveis de controle logpibpercapita e eua2 também possuem uma relação positiva com a convergência de votos, com valores superiores às das variáveis independentes escolhidas, o que denota que fatores exógenos ao fortalecimento da relação bilateral tem uma importante influência sobre a convergência de votos. Já as variáveis cplp e col tem uma relação negativa, ou seja, há uma diminuição da convergência de votos quando são considerados esses elementos.

O fato que mais chamou atenção nesses dados foi a variável lula que possui um coeficiente negativo, ou seja, de que o fato de ser o governo Lula faz com que ocorra uma diminuição de 2,15 pontos percentuais na convergência de votos. Esse resultado chamou a atenção, pois, esperava-se que houvesse um aumento na convergência de votos caso fosse encontrada uma relação positiva entre cooperação e votação, já que 
houve um aumento expressivo dos projetos de cooperação no governo Lula. Entretanto, essa expectativa foi frustrada e acabamos encontrando que o governo Lula tem um efeito negativo sobre a votação.

Uma possível explicação para esse fato é que no governo anterior o número de projetos foi muito pequeno, ou seja, a amostra de casos é muito limitada, o que fez com que o erro padrão fosse muito alto, aumentando demais o intervalo para predição, sendo impossível, portanto, encontrar uma relação estatística confiável entre as variáveis cooperação e Lula, conforme demonstra o gráfico a seguir.

Figura 35 - Margens de predição com a variável Lula

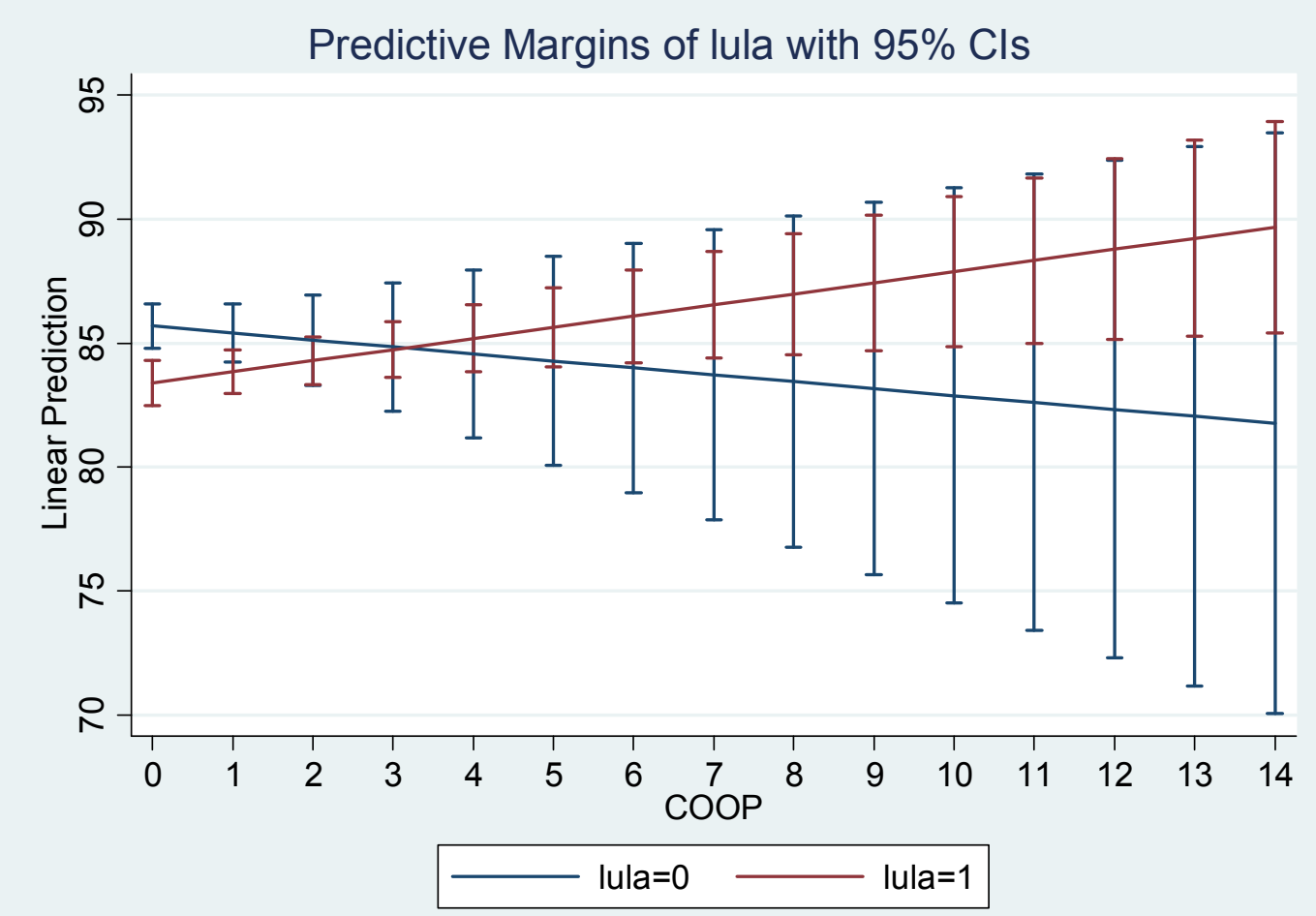


Quando substitui-se a variável importação pela variável exportação, os resultados são semelhantes ao caso anterior, exceto pela própria variável exportação que possui um valor negativo, conforme pode ser comprovado pela tabela 5 .

Tabela 5 -

\begin{tabular}{lcc} 
vot200 & Coeficiente \\
\hline coop & .3905596 \\
exp100 & -.0234868 \\
lula & -1.875475 \\
logpibperc $\sim$ a & 1.171761 \\
eua200 & .5788757 \\
cplp & -1.406769 \\
col & & \\
& 1 & -1.287292 \\
& 2 & -.7272931 \\
& 3 & -3.775539 \\
& 4 & -4.441501 \\
& 5 & -1.405062 \\
& 6 & -2.051337 \\
& 7 & $($ omitted)
\end{tabular}

Comparando à tabela anterior, percebe-se que quando são consideradas as exportações, o coeficiente entre votação e cooperação continua positivo, aumentando para 0.39 , ou seja, 1 acordo de cooperação geraria um aumento de 0.39 ponto percentual na convergência de votos entre os países africanos e o Brasil. Já a variável exportação, diferentemente da variável importação, possui uma relação negativa com a votação, ou seja, o aumento de $1 \%$ da participação brasileira nas exportações totais africanas gera uma ligeira diminuição de 0.023 ponto percentual.

Esse fato também é interessante, pois, normalmente, acredita-se que os países dão mais importância às suas vendas do que as suas comprar e, que, portanto, tenderiam convergir, nas votações da AGNU, com os países que importam seus produtos, o que não ocorreu.

Assim como no caso anterior, as variáveis de controle logpibpercapita e eua2 tem uma relação positiva com a variável dependente, com valores também superiores aos das variáveis independentes escolhidos, o que confirmaria a importância de fatores exógenos ao fortalecimento da relação bilateral na convergência de votos na AGNU. As variáveis de controle relativas ao pertencimento à CPLP e à colonização também tem uma relação negativa com a variável votação, ou seja, tem um efeito negativo sobre as mesmas. 
A variável Lula continua tendo um efeito negativo quando utiliza-se a variável exportação, o que ajudaria a confirmar o argumento acima de que não seria possível encontrar uma relação estatística entre a cooperação e Lula e a convergência de votos entre o Brasil e os países africanos.

Até o presente momento, pode-se dizer, portanto, que foi encontrada uma relação entre as variáveis independentes escolhidas - cooperação e exportação/importação - e a convergência de votos, apesar de o mesmo ser relativamente baixo, ou seja, que foram encontrados possíveis indícios de "compra" dos votos africanos pelo Brasil. Entretanto, não possível determinar a influência do governo sobre essa estratégia.

\section{Conclusão}

A área de Relações Internacionais sempre demonstrou um interesse sobre os determinantes da cooperação entre os países no plano multilateral, já que esse seria o local em que boa parte dos países se encontram para discutir os principais temas internacionais. A partir disso, diversos autores procuraram entender como ocorre a formação de alianças em organismos multilaterais, dando origem a uma literatura extensa sobre a possibilidade de que os países utilizariam certas estratégias para "comprar" os votos dos seus aliados e, dessa maneira, conseguir que as organizações internacionais tenham uma posição favorável em relação aos seus temas de interesse.

Entretanto, esses estudos tratam da "compra" de votos por parte das grandes potências, mais especificamente dos EUA, buscando comprovar que essa grande potência utilizaria a ajuda internacional para angariar o apoio dos países beneficiados pela mesma nos organismos multilaterais, não havendo, portanto, estudos que busquem verificar se essa dinâmica também estaria presente no caso dos países emergentes. 
A partir dessa lacuna na literatura sobre "compra" de votos, essa tese buscou verificar a ocorrência desse fenômeno no caso de países emergentes que buscam maior protagonismo no sistema internacional. Para isso, escolheu-se o Brasil, país que, nos anos recentes, viveu um processo de ascensão no sistema internacional e vem procurando aumentar a sua capacidade de influência sobre os seus pares, principalmente nas organizações internacionais, nas quais o seu poder de barganha pode crescer, já que as mesmas contam com muitos países semelhantes, o que favorece a possibilidade de convencimento por parte do Brasil.

Com esse objetivo em mente, foi escolhido o relacionamento brasileiro com os países africanos, já que nos anos recentes, mais especificamente do governo Lula, foram empreendidas estratégias para fortalecer as relações com esses países, sendo que uma das motivações para tal seria exatamente a busca do apoio desses países às demandas multilaterais para, dessa maneira, aumentar o protagonismo brasileiro no sistema internacional. Sendo assim, a hipótese geral dessa pesquisa seria de que os países buscariam fortalecer o seu relacionamento bilateral com vistas a angariar o apoio dos países beneficiados no plano multilateral.

Entretanto, não poderíamos utilizar a mesma variável independente da literatura sobre o tema, já que a capacidade e o montante da ajuda internacional fornecida por países em desenvolvimento como o Brasil são baixos. Para solucionar esse problema, recorreu-se aos estudos sobre a política africana que apontariam que teria ocorrido entre os governos FHC e Lula um aumento expressivo no comércio bilateral e nos projetos de cooperação com a África. Sendo assim, escolhemos como variáveis independentes de nosso modelo, o comércio bilateral e a cooperação com os países africanos.

Ao verificar de forma mais detida os dados sobre esses dois elementos, percebemos que o perfil das mesmas, apesar do discurso oficial da diversificação do relacionamento com o continente africano, não teria sofrido grandes alterações, ou seja, o relacionamento estaria concentrado nos parceiros tradicionais, como os países de língua portuguesa, África do Sul e exportadores de petróleo, como Nigéria e Argélia. Entretanto, deve-se reconhecer que houve um aumento expressivo no número de projetos de cooperação bilateral entre os dois governos, apesar de os mesmos estarem centrados quase que nos mesmos países beneficiados pelo governo anterior.

Os dados comerciais a serem considerados no modelo foram aqueles relativos à participação brasileira nas importações e exportações totais africanas, pois dessa maneira conseguiu-se apreender o verdadeiro peso do Brasil para os países africanos e, 
consequentemente, o quão o comércio bilateral poderia fazer com um país se aliasse a outro nos foros multilaterais. Percebemos que o peso brasileiro no comércio africano ainda é relativamente baixo, ocorrendo pouca alteração entre os dois governos analisados, o que aparentemente, não justificaria um possível aumento na convergência de votos.

Posteriormente, foram analisados os dados relativos à variável dependente convergência de votos entre o Brasil e os países africanos na AGNU. Percebemos que existe um alto grau de convergência entre o Brasil e a África no foro escolhido, em ambos os governos, principalmente quando são consideradas as abstenções, fazendo com que em alguns anos a convergência chegue a 100\%. Essa descoberta fez com que desconsiderássemos em nosso modelo a convergência de votos incluindo as abstenções, visto que não existe grandes variações e o ponto de convergência já é muito alto, não sendo possível, portanto, captar por meio desse dado possíveis influências das variáveis independentes na variável dependente.

Feita a análise descritiva dos dados a serem utilizados, realizamos os cálculos para testar nossa hipótese por meio do modelo de efeitos aleatórios, já que o mesmo seria suficiente para responder à nossa questão de pesquisa.

Por meio dos cálculos, conseguimos comprovar a nossa hipótese de pesquisa de que a cooperação e o comércio teriam influência sobre a convergência de votos entre os países africanos e o Brasil na AGNU. Entretanto, essa afirmação merece algumas ressalvas a partir de alguns resultados encontrados.

No caso do comércio, percebemos uma influência diferente entre as importações e as exportações, sendo que as primeiras possuem uma influência positiva sobre os votos, ou seja, seu aumento provoca também um incremento na convergência, enquanto que as segundas possuem um efeito negativo sobre a convergência, ou seja, seu aumento leva a uma diminuição na similaridade de votos. Esse resultado é interessante, pois a princípio, normalmente, somos levados a imaginar que os países dariam mais importância aos parceiros que compram os seus produtos, já que essas aumentam a capacidade do governo investir no país e também acumular reservas internacionais.

Outro fato interessante foi o fator governo, percebemos que apesar de o governo Lula ter aumentado o número de projetos de cooperação bilateral, a convergência de votos entre o Brasil e os países africanos diminui quando levamos em consideração o governo. Isso, deve-se deixar claro, não quer dizer que o governo Lula não teve influência sobre a variável cooperação, pois isso não medido pelo modelo proposto, o 
que necessitaria de outros cálculos, o que foi encontrado é que a variável Lula diminui a convergência de votos entre o Brasil e a África na AGNU.

Apesar das relações encontradas entre as variáveis dependentes e independentes, também foram encontradas relações ainda mais fortes entre as variáveis de controle e a convergência de votos entre o Brasil e o continente africano, o que leva à conclusão de que fatores exógenos ao fortalecimento do relacionamento bilateral também possuem influência sobre os votos dos países. Isso também vai ao encontro de algumas discussões da literatura de que seria muito difícil, de forma empírica, isolar todas as variáveis bilaterais das variáveis sistêmicas para encontrar possíveis indícios de "compra" de votos.

Portanto, essa tese acabou por confirmar a sua hipótese inicial de que o fortalecimento das relações bilaterais levaria ao aumento do apoio dos países beneficiados no plano multilateral também no caso de um país emergente. Entretanto, deve-se deixar claro que para que essa afirmação tenha maior validade empírica seriam necessários mais estudos com um número maior de países emergentes e seus aliados, o que inaugura para os pesquisadores de relações internacionais um campo interessante de investigação, podendo gerar achados importantes sobre os determinantes do apoio dos países nos foros multilaterais.

Sendo assim, essa tese não finda essa questão de pesquisa, pelo contrário, abre a possibilidade de novos estudos sobre a "compra" de votos nas instituições multilaterais por parte dos países emergentes que, cada vez mais, tem um peso maior no sistema internacional e não são tratados pela literatura tradicional sobre o tema. 


\section{REFERÊNCIAS BIBLIOGRÁFICAS}

ALICEWEB. Disponível em: http://aliceweb.mdic.gov.br/. Acesso em: 25 de abril de 2013.

ALGER, Chadwick F. "Interaction in a Comittee of de United Nations General Assembly" in Quantitat. International Politics, ed. David Singer. New York: The Free Pass, 1968.

ALESINA, Alberto; DOLLAR, David. "Who Gives Foreign Aid to Whom and Why?". Journal of Economic Growth, 5, 2000.

; WEDER, Beatrice. "Do Corrupt Governments Receive Less Foreign Aid?”. National Bureau of Economic Research Working Paper, n. 7108, 1999.

$$
\text { Discurso de Posse. 2003. Disponível em: }
$$

http://www.mre.gov.br/portugues/politica_externa/discursos/discurso_detalhe.asp?ID DISCURSO=2032. Acesso em 10 de agosto de 2010. 
ARMIÑO, Karlos Pérez de. Diccionario de Acción Humanitaria y Cooperación al Desarollo. Barcelona: Içaria Editorial, 2001.

BARNEBECK, Andersen et al., "On US politics and IMF lending." European Economic Review, 50, 2006.

BARRO, Robert J.; LEE, Jong-Wha. "IMF Programs: Who is chosen and what are the effects?" Journal of Monetary Economics, 52, 7, 2005.

BLACK, Lloyd. The Strategy of Foreign Aid. Princeton, N.J.: D. Van Nostrand, 1968.

BOONE, Peter. "Politics and effectiveness of foreign aid". European Economic Review, 40, 2, 1996.

BRASIL. Ministério das Relações Exteriores do Brasil. "Balanço de Política Externa 2003-2010", 2010. Disponível em: http://www.itamaraty.gov.br/temas/balanco-depolitica-externa-2003-2010. Acesso em 25 de junho de 2011.

BUENO DE MESQUITA, Bruce; MORROW, James D.; SIVERSON, Randolph M.; SMITH, Alasteir. The Logic of Political Survival. Cambridge: MIT Press, 2003.

Cameron, A. C. e Travedi, P. K. Microeconometrics: methods and applications. Cambridge Univ. Press, Nova Iorque, 2005.

CASHEL-CORDO, Peter; CRAIG, Steven G. "Donor Preferences and Recipient Fiscal Behavior: a Simultaneous Analysis of Foreign Aid”. Economic Inquiry, v. 35, 3, 1997.

COLLIER, Paul; DOLLAR, David. “Aid Allocation and poverty reduction”. European Economic Review, v. 46, 8, 2002.

DHARENDORF, Ralf. La cuadratura del círculo. México: Fondo de Cultura Económica, 1995.

DOUCOLIAGOS H.; PALDAM, M. A meta-analysis of development aid allocation: the effects of income level and population size.Working paper, 2007.

DREHER, Axel; NUNNEMKAMP, Peter; THIELE, Rainer. "Does US Aid buy UN general assembly votes? A disaggregated analysis”. Public Choice, 136, 2008.

; STURM, Jan-Egbert; VREELAND, James Raymond. "Global horse trading: IMF loans for votes in the United Nations Security Council". European Economic Review, 53, 2009.

DIVISÃO DE ATOS INTERNACIONAIS DO MINISTÉRIO DAS RELAÇÕES EXTERIORES DO BRASIL (DAI-MRE). Disponível em: http://dai-mre.serpro.gov.br/. Acesso em: 28 de setembro de 2013.

GARTZKE, Erik. "Kant We All Just Get Along?: Opportunity, Willingness, and the Origins of the Democratic Peace”. American Journal of Political Science, 42, 1998. 
HARIGAN ET AL. "The economic and political determinants of IMF and World Bank lending in the Middle East and North Africa”. World Development, 34(2), 2006.

HAUSMAN, J. Specification tests in econometrics. Econometrica. Vol. 46. nº 6. 1978. HSIAO, Cheng. Analysis of Panel Data. Cambridge. Ed. Cambridge Univ. Press. 1986. INSTITUTO DE PESQUISA APLICADA IPEA. Ponte sobre o Atlântico: o Brasil e a África Subsaariana. Parceria Sul-Sul para o crescimento. Brasília: IPEA, 2011. JÚNIOR, Wilson Mendonça. Política Externa e cooperação técnica: as relações do Brasil com a África durante os anos FHC e Lula da Silva. Belo Horizonte: D’Plácido Editora, 2013.

KAPLAN, Jacob J. The Challenge of Foreign Aid. New York: Praeger, 1967.

KEGLEY, Charles W; HOOK, Steven W. "U.S. foreign aid and U.N. voting: did Reagan's linkage strategy buy defense or defiance?". International Studies Quarterly, 35(3), 1991.

KEOHANE, Robert. "Political Influence in the General Assembly". International Conciliation, n. 557, 1966.

KILBY, Christopher. "An empirical assessment of informal influence in the World Bank”. Economic Development and Cultural Change, 61 (2), 2013.

KIM, Soo Yeon; RUSSETT, Bruce. "The New Politics of Voting Alignments in the United Nations General Assembly”. International Organization, 50(4), 1996.

KUZIEMKO, Ilyana; WERKER, Eric. "How much is a seat on the Security Council worth? Foreign Aid and bribery at the United Nations". Journal of Political Economy, v. 114, n. 5, 2006.

LAMPREIA, Luiz Felipe. Diplomacia brasileira. Rio de Janeiro: Lacerda Editora. 1999.

LANGHAMMER, R. J. "Halving poverty by doubling aid: is there reason for optimism?" The World Economy, 27(1)2004.

LESSA, Antônio Carlos. "A diplomacia universalista do Brasil: a construção do sistema contemporâneo de relações bilaterais.”. RBPI, v. 41, n. 2, p. 37, 1998.

LIMA, Maria Regina Soares de. "A política externa brasileira e os desafios da cooperação Sul-Sul.” Revista Brasileira de Politica Internacional, vol.48, n.1, 2005.

LOPES, Carlos. Cooperação e Desenvolvimento Humano: a agenda emergente para o novo milênio. São Paulo: UNESP, 2005.

. “A África entre o Brasil e a China”. Estudos Afro-Asiáticos, ano 29, n. 1, 2, 3, 2007. 
MAIZELS, Alfred; NISSANKE, Machiko. "Motivations for Aid to Developing Countries." World Development, v. 12, n. 9, p. 879, 1984.

MASON, Edward S. Foreign Aid and Foreign Policy, New York: Harper and Row, 1964.

MENON, Bashkar P. Bridges across the South. New York: Pergamon, 1980.

MINISTÉRIO DAS RELAÇÕES EXTERIORES DO BRASIL (MRE). Balanço de Política Externa 2003-2010: África. 2010. Disponível em: http://www.itamaraty.gov.br/temas/balancodepoliticaexterna20032010/2.2.3africacomercioeinvestimentos/view. Acesso em: 25 de junho de 2011.

MINISTÉRIO DO DESENVOLVIMENTO, INDÚSTRIA E COMÉRCIO (MDIC). Estatísticas de Comércio Exterior. Disponível em: http://www.mdic.gov.br//sitio/interna/interna.php?area=5\&menu=576. Acesso em: 17 de julho de 2011.

MIYAMOTO, Shiguenoli. "O Brasil e as negociações multilaterais”. RBPI, 43, (1), 2000 .

MOON. Consensus or compliance? Foreign policy change and external dependence. International Organisation 39 (2), 1985.

MORGENTHAU, Hans. "A Political Theory of Foreign Aid". American Political Science Review, 56(2), 1962.

NEUMAYER, Eric. "The Determinants of Aid Allocation by Regional Multilateral Development Bank and United Nations Agencies". International Studies Quarterly, 47, $1,2003$.

ONEAL, John; RUSSETT, Bruce. "Assessing the liberal peace with alternative specifications: trade still reduces conflict”. Journal of Peace Research, 36(4), 1999.

OATLEY, Thomas; YACKEE, Jason. "American Interests and IMF Lending". International Politics, 41, 2004.

PIMENTEL, José Vicente. "Relações entre o Brasil e a África Sub-Saariana”. RBPI, v. 43, n. $1,2000$.

PLANO, Jack; RIGGS, Robert. Forging World Order, New York: Macmillan, 1967.

PLONSKI, Guilherme Ary. “A administração de projetos aplicada ao ambiente da cooperação técnica internacional: visão de conjunto". In: MARKOVITCH, Jacques (org.). Cooperação Internacional: estratégia e gestão. São Paulo: Editora da Universidade de São Paulo, 1994. 
POTRAFKE, Niklas. "Does government ideology influence political alignment with the U.S.? An empirical analysis of voting in the UN General Assembly". The Review of International Organizations, 2009.

PUENTE, Carlos Alfonso Iglesias. A cooperação técnica horizontal brasileira como instrumento e política externa: a evolução da cooperação técnica com países em desenvolvimento - CTPD - no período 1995-2005. Brasília: FUNAG, 2010.

RAI, Kul B. "Foreign Aid and Voting in the UN General Assembly, 1967-1976". Journal of Peace Research, 17, 3, 1980.

SARAIVA, José Flávio Sombra. "Política Exterior do Governo Lula: o desafio africano". RBPI, n. 45, v. 2, 2002.

- "The New Africa and Brazil in the Lula era: the rebirth of Brazilian Atlantic Policy". RBPI, special edition, 2010.

SCHRAEDER, P. ET AL. "Clarifying the foreign aid puzzle: a comparison of American, Japanese, French, and Swedish aid flows”. World Politics, 50, 1998.

SILVA, Luís Inácio Lula da. Discurso de Posse no Congresso Nacional. 2003. Disponível em: http://www.biblioteca.presidencia.gov.br/ex-presidentes/luiz-inaciolula-da-silva/discursos-de-posse/discurso-de-posse-10-mandato/view. Acesso em: 21 de janeiro de 2014.

SOARES, Guido F. S. “A cooperação técnica internacional”. In: MARCOVITCH, Jacques (org.) Cooperação Internacional: estratégia e gestão. São Paulo: Editora da Universidade de São Paulo, 1994.

STEINWAND, Martin C; STONE, Randall W. "The International Monetary Fund: A review of the recent evidence". The Review of International Organizations, 3 (2), 2008. SVENSSON, J. “Aid, Growth and Democracy”. Economics \& Politics, 11, 3, 1999. THACKER, Strom C. “The High Politics of IMF Lending”. World Politics, 52, 1, 1999. VALLER FILHO, Wladimir. O Brasil e a crise haitiana: a cooperação técnica como instrumento de solidariedade e de ação diplomática. Brasília: FUNAG, 2007.

VEIGA, Pedro da Motta. "A política comercial do governo Lula: continuidade e inflexão.” Revista Brasileira de Comércio Exterior, 83, 2005.

VIGEVANI, Tullo e OLIVEIRA, Marcelo Fernandes de. "A política externa no governo FHC: a busca de autonomia pela integração". Revista Tempo Social, 15 (2) 2003.

; CEPALUNI, Gabriel. “A política externa de Lula da Silva: a estratégia da autonomia pela diversificação." Contexto Internacional, vol.29, n.2, 2007. 
VIZENTINI, Paulo Fagundes. “A África na Política Internacional. Curitiba: Editora Juruá, 2010.

VOETEN, Erik. "Clashes in the Assembly". International Organization, 54(2), 2000.

WANG, T. Y. "U.S. Foreign Aid and UN Voting: An Analysis of Important Votes". International Studies Quarterly, 43, 1999.

WEIGERT, Kathleen Mass Weigert; RIGGS, Robert E. "Africa and United Nations Elections: an Aggregate Data Analysis”. International Organization, 23, 1969.

WESTWOOD, Andrew F. Foreign Aid in a Foreign Policy Framework. Washington, D.C.: The Brookings Institution, 1966.

WILCOX, Francis O. "The Nonaligned States and the United Nations" in Neutralism and Nonalignment. Ed. Laurence Martin. New York: Praeger, 1962.

WITTKOPF, William. "Foreign Aid and United Nations Votes: A Comparative Study". The American Political Science Review, v. 67, n.3, 1973. 